MARIANA MOLINA

\title{
Abordagem para análise proteômica de neurônios contendo neuromelanina na substância negra, isolados por microdissecção a laser
}

\begin{abstract}
Dissertação apresentada à Faculdade de Medicina da Universidade de São Paulo para obtenção do título de Mestre em Ciências

Programa de Fisiopatologia Experimental Orientador: Prof. $\stackrel{a}{ }$ Dr. $\stackrel{a}{ }$ Lea Tenenholz Grinberg
\end{abstract}

São Paulo 
Dados Internacionais de Catalogação na Publicação (CIP)

Preparada pela Biblioteca da

Faculdade de Medicina da Universidade de São Paulo

Creprodução autorizada pelo autor

\section{Molina, Mariana}

Abordagem para análise proteômica de neurônios contendo neuromelanina na substância negra, isolados por microdissecção a laser / Mariana Molina. -- São Paulo, 2015.

Dissertação(mestrado)--Faculdade de Medicina da Universidade de São Paulo. Programa de Fisiopatologia Experimental.

Orientadora: Lea Tenenholz Grinberg.

Descritores: 1.Neurônios 2.Substância negra 3.Neuromelanina 4.Microdissecção e captura a laser 5.Proteômica

USP/FM/DBD-412/15 


\section{NORMALIZAÇÃO ADOTADA}

Esta dissertação está de acordo com as seguintes normas, em vigor no momento desta publicação:

Referências: adaptado de International Committee of Medical Journals Editors (Vancouver).

Universidade de São Paulo. Faculdade de Medicina. Divisão de Biblioteca e Documentação. Guia de apresentação de dissertações, teses e monografias. Elaborado por Anneliese Carneiro da Cunha, Maria Julia de A. L. Freddi, Maria F. Crestana, Marinalva de Souza Aragão, Suely Campos Cardoso, Valéria Vilhena. 3a ed. São Paulo: Divisão de Biblioteca e Documentação; 2011.

Abreviaturas dos títulos dos periódicos de acordo com List of Journals Indexed in Index Medicus. 


\section{DEDICATÓRIA}

As minhas avós

Fontes de inspiração. Sustentáculos da minha vontade de persistir.

Aos meus pais

Quão difícil é expressar a minha gratidão. É árdua a tarefa de exprimir em palavras tudo o que fizeram e fazem por mim. Incansavelmente me apoiam e são responsáveis pela realização de muito dos meus sonhos, para isso, renunciaram aos próprios. Sinto-me no dever de agradecer-lhes incessantemente.

\section{A minha irmã Danielle}

Faço minhas, as palavras de Elton John e Bernie Taupin: "How wonderful life is while you're in the world".

\section{Ao meu irmão Raphael}

Quando eu crescer, eu quero ser como você! Inspiração de trabalho, dedicação e carinho.

Eu me sinto indefinivelmente grata e honrada por ter vocês. 


\section{AGRADECIMENTOS}

À minha orientadora, Prof. ${ }^{\text {a }}$ Dr. a Lea Tenenholz Grinberg, exemplo de profissional, de mulher e de pessoa. O meu profundo agradecimento pela oportunidade e o privilégio que tive em ser sua orientanda que muito contribuiu para o enriquecimento da minha formação acadêmica e científica.

À minha co-orientadora, Prof. ${ }^{a}$ Dr. ${ }^{a}$ Renata Elaine Paraizo Leite, por ter me conduzido nos caminhos da ciência de forma brilhante, desde os tempos de iniciação científica. Agradeço pela disponibilidade, estímulo constante e o imprescindível apoio na elaboração deste trabalho.

Meus agradecimentos, cordialidade e respeito aos professores, Dr. Wilson Jacob Filho, Dr. Carlos Augusto Pasqualucci e Dr. Ricardo Nitrini pelo apoio, por todos os auxílios e pela ampla colaboração com o Grupo de Estudos em Envelhecimento Cerebral. Grandes fontes de inspiração.

Ao Prof. Dr. Helmut Heinsen por sua paciência e disposição indefectível em ajudar e toda a sua colaboração com esse projeto.

Aos professores e coordenadores do Grupo de Estudos em Envelhecimento Cerebral, Dr. ${ }^{\text {a }}$ Claudia Suemoto, Dr. José Marcelo Farfel, Dr. ${ }^{a}$ Renata Ferretti Rebustini pela disponibilidade, ensinamentos e apoio científico.

À Ana Tereza Di Lorenzo Alho, à Camila Nascimento Mantelli, à Luzia Lima, à Kátia Cristina Oliveira, mais do que colegas do Gerolab, amigas que transmitiram, além de conteúdos, sentimentos de amizade, solidariedade, segurança e confiança. É inestimável percorrer o caminho da ciência ao lado de vocês!

À Roberta Diehl Rodriguez, pelo apoio irrestrito. A minha gratidão e amizade. 
À querida Marta Crocci, pela prontidão em ajudar, pelo apoio afetuoso e pela amizade.

Ao Gustavo Ribeiro pela presteza e discrição.

À Keila Maria pelo apoio, amizade e a preocupação.

À Prof. Dr. ${ }^{a}$ Katrin Marcus, Dr. a Caroline May, Dr. Stefan Helling, Sarah Plum, Simone Kutschki, Jale Stoutjesdijk, Prabal Subedi, Janine Brunner, Katrin Barlog e a todos do Centro de Proteômica Médica da Universidade de Bochum, pela colaboração, por me receberem e por me ensinarem pacientemente tudo o que sei sobre proteômica. O meu mais sincero Vielen Dank.

Aos professores, Dr. Alexandre Valotta da Silva, Dr. Jackson Cioni Bittencourt e Dr. Luiz Roberto Giorgetti de Britto pelo brilhantismo que conduziram a minha banca de qualificação, com suas valiosas contribuições.

Ao Prof. Dr. Jarbas Arruda Bauer, por toda sua competência e por partilhar seus conhecimentos.

Ao Prof. Dr. Chin Jia Lin e à Natália Gomes Gonçalves, sempre solícitos e dispostos a ajudar.

Ao Eduardo Alho por seus valiosos ensinamentos durante a visita a Universidade de Würzburg.

Ao André Schwambach Vieira, pós doutorando da FCM da UNICAMP, prestativo, abriu as portas do laboratório de Génetica Molecular para que eu pudesse realizar as microdissecções no momento em que o microscópio da FMUSP não estava disponível. 
À Anna Carla Goldberg e ao Thiago Pinheiro Arrais Aloia e pela amabilidade em dispor o seu laboratório no Centro de Pesquisa Experimental no Instituto Israelita de Ensino e Pesquisa Albert Einstein para que eu pudesse realizar as microdissecções no momento em que ambos os microscópios da FMUSP e da UNICAMP não estavam disponíveis.

À todos os membros e ex-membros do Grupo de Estudos em Envelhecimento Cerebral. Pela dedicação admirável, companheirismo e apoio. O trabalho de toda equipe foi imprescindível no desenvolvimento deste trabalho.

À Aline Nishizawa, Daniela Souza Farias, Perola Branca, Fernanda Marinho Campos, Karen Cristina por me receberem gentilmente no laboratório de patologia cardiovascular quando precisei realizar os cortes em criostato.

À Dr. . Inês Liguore Padrão, que cedeu generosamente seu tempo para me ensinar um pouco sobre histologia do sistema nervoso e as alterações vasculares.

Aos funcionários do programa de pós-graduação em fisiopatologia experimental pela atenção e disposição.

À Coordenação de Aperfeiçoamento de Pessoal de Nível Superior pela concessão da bolsa de mestrado.

Ao Conselho Nacional de Desenvolvimento Científico e Tecnológico pelo apoio financeiro.

Aos funcionários do Serviço de Verificação de Óbitos da Capital pela colaboração para com o Grupo de Estudos em Envelhecimento Cerebral.

Aos familiares doadores, solidários mesmo em meio ao luto. Este trabalho existe a partir deles e deverá retornar para eles. 


\section{SUMÁRIO}

LISTA DE ABREVIATURAS, SIGLAS E SÍMBOLOS

LISTA DE GRÁFICOS

LISTA DE FIGURAS

LISTA DE TABELAS

RESUMO

SUMMARY

1. INTRODUÇÃO

$1.1 \quad$ Envelhecimento populacional ................................................. 2

1.2 Envelhecimento e a doença de Parkinson.......................................... 5

1.3 Substância Negra .................................................................. 7

1.4 Microdissecção a laser e a proteômica.............................................. 13

2. OBJETIVOS

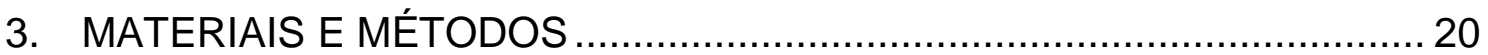

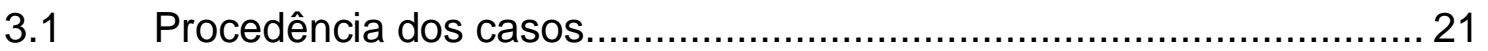

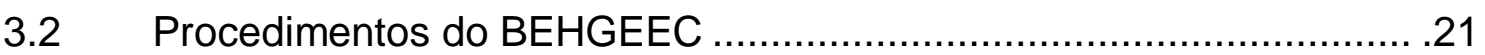

3.3 Critérios de seleção de casos para o presente estudo …...................26

3.4 Estabelecimento do protocolo para a realização da técnica de

microdissecção e captura a laser .............................................................. 26

3.5 Otimização do protocolo de preparação das amostras para

espectrometria de massas ......................................................................... 32

3.6 Isolamento das amostras através da técnica de microdissecção a

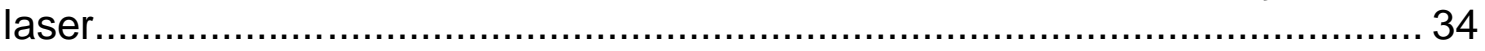

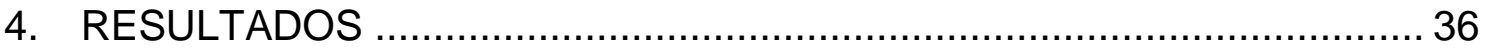

4.1 Protocolo para a realização da técnica de MCL ................................ 37

4.2 Otimização do protocolo de preparação das amostras para

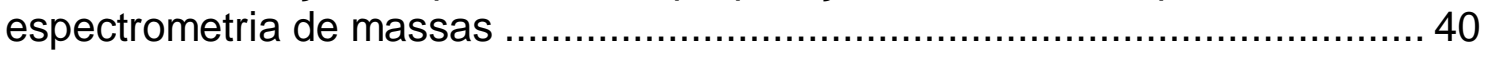

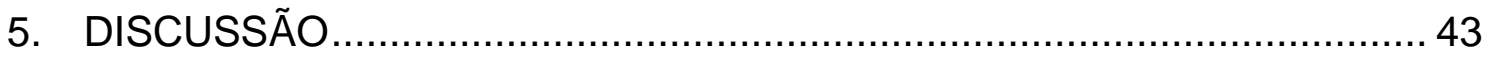

5.1 Plano anatômico ideal para a MCL da substância negra..................... 45

5.2 Processo de congelamento para MCL.............................................. 46

5.3 Espessura do corte para MCL ............................................... 47

$5.4 \quad$ Coloração para MCL................................................................... 48

5.5 Microdissecção e captura a laser .................................................. 50

5.6 Preparação das amostras para espectrometria de massas.................. 52

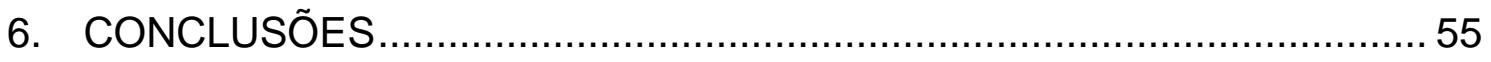

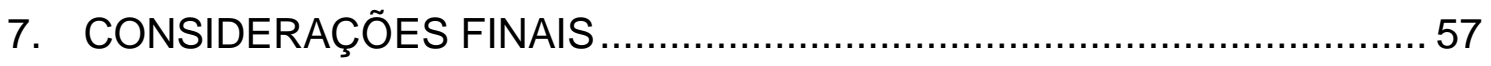

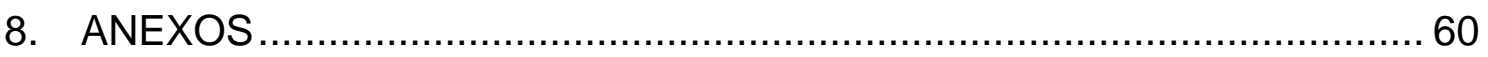




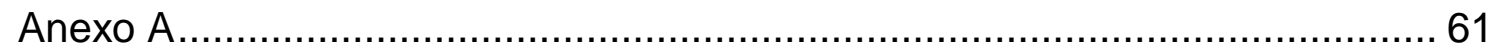

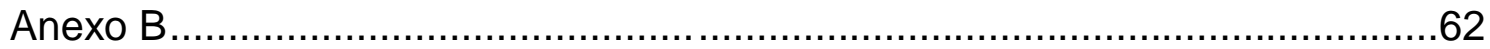

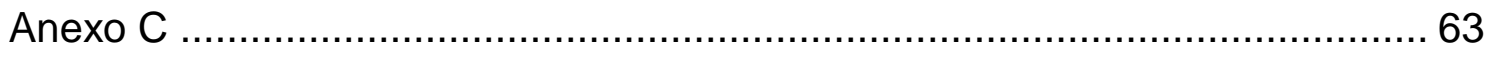

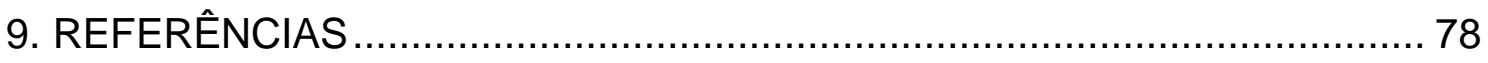




\title{
LISTA DE ABREVIATURAS, SÍMBOLOS E SIGLAS
}

\author{
5-HT 5-hidroxitriptamina \\ A $\quad$ Ångström \\ ul Microlitros \\ $\mu \mathrm{m} \quad$ Micrômetros \\ $\mu \mathrm{m}^{2} \quad$ Micrômetros quadrados \\ $\mu \mathrm{m}^{3} \quad$ Micrômetros cúbicos \\ Ach Acetilcolina \\ ACN Acetonitrila \\ AF Ácido Fórmico \\ BEHGEEC Banco de Encéfalos Humanos do Grupo de Estudos em \\ Envelhecimento Cerebral \\ CDR Questinário para Avaliação Clínica da Demência \\ CG Cromatografia Gasosa \\ $\mathrm{CL} \quad$ Cromatografia Líquida \\ $\mathrm{cm} \quad$ Centímetros \\ CPM Centro de Proteômica Médica \\ DA Doença de Alzheimer \\ DP Doença de Parkinson \\ ESI Electrospray lonization \\ FMUSP Faculdade de Medicina da Universidade de São Paulo \\ GABA Ácido Gama-Aminobutírico \\ Glu Glutamato \\ GPe Globo Pálido externo \\ GPi Globo Pálido interno \\ HC Hospital das Clínicas \\ $\mathrm{HCl}$ Ácido Clorídrico \\ HE Hematoxilina e Eosina \\ HPLC High Performance Liquide Chromatography \\ IBGE Instituto Brasileiro de Geografia e Estatística \\ IT Ion Trap \\ LC-MS/MS Liquid Chromatography - Mass Spectrometry/Mass \\ Spectrometry
}




\begin{tabular}{ll} 
MALDI & Matrix-Assisted Laser Desorption/lonization \\
MCL & Microdissecção e Captura a Laser \\
mm & Milímetro \\
Min & Minuto \\
MS & Mass Spectrometry \\
ms & Milissegundos \\
m/z & Massa/carga \\
NA & Noradrenalina \\
ng & Nanogramas \\
NINDS & National Institute of Neurological Disorders and Stroke \\
NIH & National Institutes of Health \\
NL & Neuritos de Lewy \\
nm & Nanômetros \\
ONU & Organização das Nações Unidas \\
pH & Potencial Hidrogênionico \\
pmol & Picomol \\
RP & Reversed Phase \\
sec & Segundos \\
SIM & Selected-lon Monitoring \\
SVOC & Serviço de Verificação de Óbitos da Capital \\
SN & Substância Negra \\
SNpc & Substância Negra pars compacta \\
SNpd & Substância Negra pars diffusa \\
SNpr & Substância Negra pars reticulata \\
TA & Temperatura Ambiente \\
TOF & Time Of Flight \\
UPLC- & Ultra Performance Liquid Chromatography - Tunable UV \\
TUV & Detector \\
& \\
\hline
\end{tabular}




\section{LISTA DE GRÁFICOS}

Gráfico 01 - Projeções da população brasileira 4 


\section{LISTA DE FIGURAS}

Figura 01 - Porcentagem da população com 60 anos ou mais, estimada para

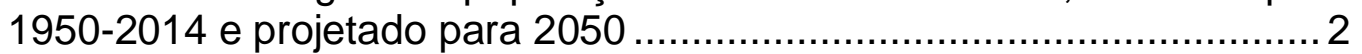

Figura 02 - População de idosos estimada em 2014 e projetada para 2015

Figura 03 - Fotografia da substância negra ............................................. 6

Figura 04 - Localização da substância negra ............................................ 7

Figura 05 - Diagrama dos tipos neuronais na substância negra.................... 8

Figura 06 - Modelo esquemático das conexões sinápticas dos neurônios da substância negra pars compacta ....................................................... 9

Figura 07 - Representação do mesencéfalo através de um plano de corte horizontal................................................................................. 11

Figura 08 - Regiões encefálicas contendo células produtoras de neuromelanina

Figura 09 - Exemplo do sistema de HPCL acoplado ao espectrômetro de massas e diagrama de espectrometria de massas em tandem ............ 16

Figura 10 - Procedimento do corte do tronco encefálico para a

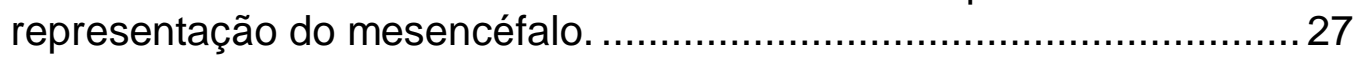

Figura 11 - Procedimento de corte no criostato ………….........................29

Figura 12 - Imagem representativa do sistema PALM MicroBeam...............30

Figura 13 - Seleção da área para realizar a MCL.......................................35

Figura 14 - Diferença neuroanatômica dos neurônios da substância negra

Figura 15 - Comparação da otimização do procedimento de congelamento para MCL

Figura 16 - Otimização da espessura ideal para o isolamento de neurônios da substância negra

Figura 17 - Análise por espectrometria de massas da substância negra ....42 


\section{LISTA DE TABELAS}

Tabela 01 - Regiões amostradas pelo protocolo do BEHGEEC

Tabela 02 - Áreas imunocoradas e anticorpos rotineiramente utilizados no BEHGEEC......

Tabela 03 - Visão geral dos procedimentos de congelação 28

Tabela 04 - Procedimento de coloração violeta de cresila 30 


\section{RESUMO}

Molina M. Abordagem para análise proteômica de neurônios contendo neuromelanina na substância negra, isolados por microdissecção a laser. [dissertação]. São Paulo: Faculdade de Medicina, Universidade de São Paulo; 2015.

Atualmente observa-se que a proporção de pessoas com 60 anos ou mais está crescendo mais rápido do que a de outras faixas etárias. Um dos resultados desta transição epidemiológica é o aumento das doenças cujo fator de risco é o envelhecimento, entre elas, a doença de Parkinson. Embora muitas regiões exibam os sinais neuropatológicos da doença de Parkinson, a degeneração dos neurônios, contendo neuromelanina, da substância negra é considerada como sendo uma característica importante, representando o critério cardinal para o diagnóstico. No entanto, ainda não está claro por que certas regiões do cérebro, como a substância negra, são vulneráveis em algumas doenças neurodegenerativas e alguns neurônios vizinhos, às vezes morfologicamente indistinguíveis, permanecem preservados. Análises moleculares de populações de neurônios podem conduzir a uma melhor compreensão sobre a fisiologia dos mesmos, bem como os mecanismos envolvidos nos processos de doença. $\mathrm{Na}$ era pós genômica, realizar análises proteômicas são de grande interesse científico, pois permitem avanços no conhecimento dos processos biológicos. A técnica de microdissecção e captura a laser tem sido uma ferramenta importante e cada vez mais utilizada para aquisição de populações puras de células a partir de secções histológicas, evitando que áreas não pertencentes ao tecido alvo sejam dissecadas. A união destes métodos pode contribuir de maneira relevante para o entendimento fisiopatológico dos neurônios contendo neuromelanina da substância negra. No entanto, para que a microdissecção e captura a laser e as análises proteômicas sejam eficazes, é imprescindível a aplicação de um protocolo bem estruturado. Dentro desse contexto, o presente trabalho tem como objetivo criar um protocolo de microdissecção a laser de neurônios contendo neuromelanina em indivíduos cognitivamente normais, para subsequente análise proteômica. Os casos utilizados neste estudo são provenientes do Banco de Encéfalos Humanos do Grupo de Estudos em Envelhecimento Cerebral. Para o desenvolvimento da nossa proposta, contamos com a colaboração do Centro de Proteômica Médica da Universidade de Bochum, Alemanha. O protocolo foi desenvolvido baseado em outros previamente descritos na literatura e otimizado de acordo com objetivos pretendidos. Analisamos o plano anatômico de amostragem do tecido, 0 método de congelamento, a espessura do corte para a microdissecção, a solução utilizada para a coleta do tecido durante a microdissecção e o método de digestão proteolítica para posteriores análises proteômicas. Através de ensaios comparativos, alcançamos os resultados desejados e os mesmos foram validados através de análises por espectrometria de massas. Consequentemente, também fomos capazes de reconhecer fatores técnicos que possivelmente impossibilitariam um efetivo estudo do proteoma.

Descritores: neurônios, substância negra, neuromelanina, microdissecção e captura a laser, proteômica 


\section{SUMMARY}

Molina M. An approach to proteomics analysis of neurons containing neuromelanin in the substantia nigra, isolated by laser microdissection [dissertation]. São Paulo: "Faculdade de Medicina, Universidade de São Paulo"; 2015.

Currently the worldwide proportion of people aged 60 years and over is growing faster than any other age group. This strikingly epidemiological transition results in an increase of aging related diseases, including Parkinson's disease (PD). Although many brain areas exhibit the neuropathological signs of Parkinson's disease, the degeneration of neuromelanin containing cells in the substantia nigra is considered a hallmark feature, representing cardinal diagnostic criteria for PD. However, why certain brain regions -- such as the substantia nigra -- are vulnerable in some neurodegenerative diseases, while some neighboring morphologically indistinguishable neurons remain preserved, is still unclear. Molecular analysis of specific neuronal populations can lead us to a better understanding about the physiological role played by these neurons and mechanisms involved in disease's processes. In a post-genomic era, proteomic analyses are of great scientific interest since they allow a better understanding of the biological processes. The laser capture microdissection technique has also became an important tool in biological research, being increasingly used for acquisition of pure populations of cells from histological sections, preventing the dissection of areas outside the target tissue. The combination of these methods can significantly contribute to understand the pathophysiological role of the containing neuromelanin neurons of the substantia nigra. However, for an effective application of both techniques, laser capture microdissection and proteomic analysis, it is essential the application of an efficient protocol. In this context, this study aims to establish a protocol for laser microdissection of containing neuromelanin neurons in cognitively normal individuals for subsequent proteomic analyses. We selected cases from the Brain Bank of the Brazilian Aging Brain Study. A collaboration with the Medical Proteome Center, University of Bochum, Germany took part during the development of our proposal. Our protocol was developed based on previous published protocols and optimized according the intended aims. We analyzed anatomical planes for neuronal collection, freezing methods, thickness of tissue for microdissection sections, solution for tissue collection during laser microdissection and the proteolytic digestion methods. Through our comparative tests, we have achieved the desired results and validated them by mass spectrometry analyses. Consequently, we were also able to exclude technical factors that could possibly preclude one effective proteome analysis.

Descriptors: neurons, substantia nigra, neuromelanin, laser capture microdissection, proteomics. 


\subsection{Envelhecimento populacional}

Em todo o mundo, observa-se que a proporção de pessoas com 60 anos ou mais está crescendo mais rápido que a de qualquer outra faixa etária. Este processo que se iniciou no final do século XIX em alguns países da Europa, estendeu-se pelos países desenvolvidos e nas últimas décadas, pelos países em desenvolvimento (Carvalho e Garcia, 2003; Organização das Nações Unidas (ONU), 2014) (Figura 01).

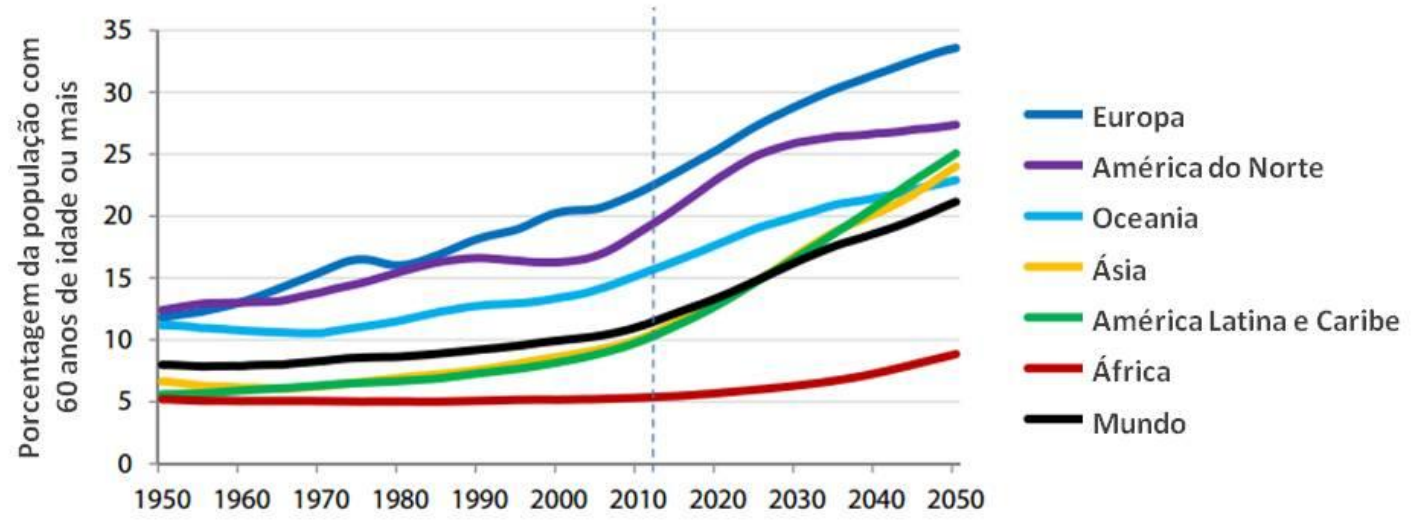

Figura 01. Porcentagem da população com 60 anos ou mais, estimada para 1950-2014 e projetado para 2050. Modificado de Organização das Nações Unidas, 2014.

Em 1950, estimava-se cerca de 205 milhões de idosos no mundo, sendo que apenas três países possuíam mais do que 10 milhões de indivíduos idosos: China (42 milhões), Índia (20 milhões) e Estados Unidos (20 milhões) (ONU, 2002). Em 2014, o número de pessoas com 60 anos ou mais aumentou cerca de quatro vezes, um crescimento de quase 13 milhões de idosos por ano e projeções realizadas pelo Departamento das Nações Unidas para Assuntos Econômicos e Sociais indicam que até 2100 a população mundial deverá triplicar, aumentando para aproximadamente três bilhões (ONU, 2014). 
Atualmente o processo de envelhecimento populacional tem ocorrido de maneira mais acentuada em regiões menos desenvolvidas. Até 2050, é estimado que a população de idosos na África triplique, podendo atingir 212 milhões, na América Latina e Caribe deverá alcançar o número de 196 milhões e na Ásia essa população poderá ser de 1,2 bilhões (ONU, 2014). Além disso, observa-se um aumento expressivo na população com 80 anos ou mais. Em 2014, entre a população idosa, cerca de 14\% dos indivíduos tinham 80 anos ou mais. Em 2050, espera-se que essa população seja de aproximadamente 392 milhões de pessoas, totalizando 19\% da população idosa (ONU, 2014) (Figura 02).

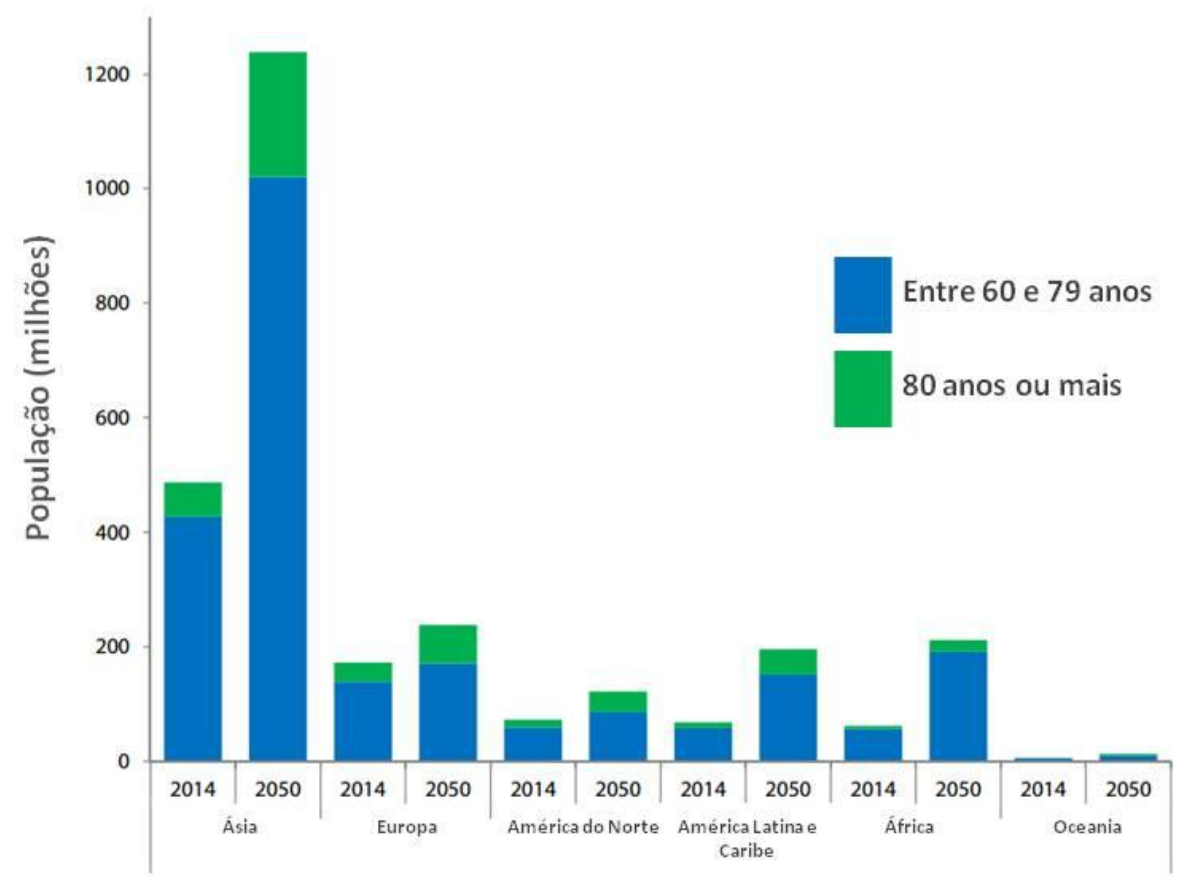

Figura 02. População de idosos, estimada em 2014 e projetada para 2050. Modificado de ONU, 2014.

Entre os países mais populosos, o Brasil apresenta um dos processos mais agudos de envelhecimento populacional (Giatti, 2003). Segundo o Instituto Brasileiro de Geografia e Estatística (IBGE), em 2002, a população com 60 anos ou mais era de aproximadamente 14 milhões de pessoas. Em 2013, a população idosa brasileira alcançou o número de 22 milhões e as estimativas são de que até 2050 a população idosa poderá ser superior a 66 
milhões, representando quase $30 \%$ da população brasileira total (Gráfico 01) (IBGE, 2013).

\section{Projeções da População Brasileira (2000-2050)}

180.000 .000

160.000 .000

140.000 .000

120.000 .000

100.000 .000

80.000 .000

60.000 .000

40.000 .000

20.000 .000

0

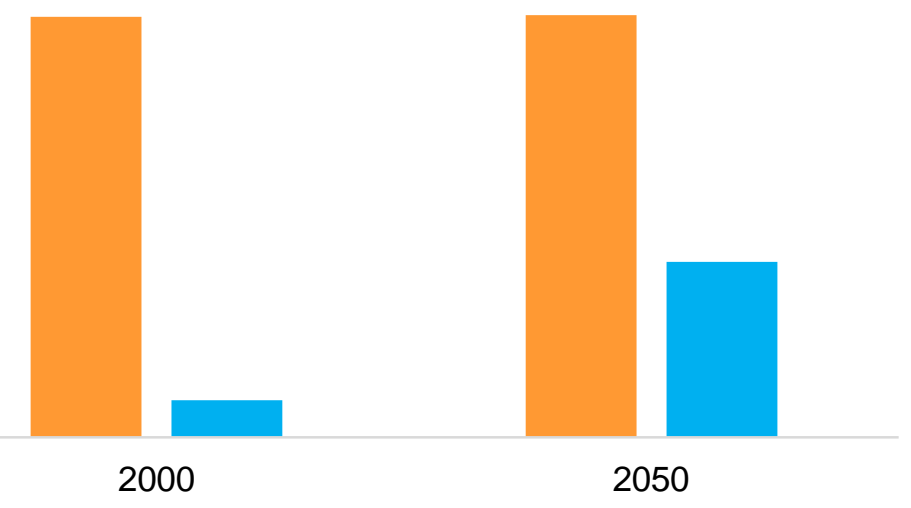

$=0-59 \square 60-90+$

Gráfico 01. Projeções da população brasileira (2000-2050). Arquivo pessoal. Fonte dos dados: IBGE (2013).

O processo de envelhecimento populacional conhecido como "transição epidemiológica" deve-se, principalmente, ao declínio da fecundidade e ao aumento na expectativa de vida (Leme, 1997; ONU 2002) duas tendências que, normalmente estão associadas ao desenvolvimento social e econômico (Ramos et al., 1987; ONU, 2013).

Em relação ao declínio da fecundidade, nos países desenvolvidos a média da taxa de fecundidade, entre 1950-1955 era de 2,8 filhos por mulher e entre 2000 a 2005 esta média diminuiu para 1,5 filhos por mulher (ONU, 2002). Já nos países menos desenvolvidos o declínio da fecundidade começou mais tarde e assim como o processo de envelhecimento populacional, ocorreu mais rápido. A maior redução do nível de fecundidade ocorreu, em geral, durante as últimas três décadas do século XX. Nos últimos 50 anos, a taxa de fecundidade total média nessas regiões caiu mais de $60 \%$, de 6,2 filhos por mulher em 1950-1955 para 2,9 em 2000-2005 (ONU, 2002).

O aumento da longevidade também contribui para o envelhecimento da população. Globalmente, a expectativa de vida ao nascer deverá aumentar de 
69 anos, para 76 anos em 2045-2050 e para 82 anos entre 2095-2100 (ONU, 2013). De acordo com recentes análises realizadas pelo IBGE, no Brasil a expectativa de vida em 1940 não atingia os 50 anos de idade. Já em 2004 a expectativa de vida ao nascer alcançava cerca de 71,2 anos, e em 2040 estima-se que a expectativa alcance a média de 80 anos (IBGE, 2008).

Um dos resultados dessa transição epidemiológica é aumento na incidência e prevalência de doenças relacionadas ao envelhecimento, entre elas as doenças neurodegenerativas. É importante ressaltar que, embora as doenças neurodegenerativas afetem principalmente pessoas idosas, elas não são parte do envelhecimento normal (Nelson et al., 2011). O caráter progressivo e irreversível de tais doenças associado à ausência de tratamentos eficazes e ao grande impacto social e econômico, têm atraído muita atenção.

\subsection{0 envelhecimento e a doença de Parkinson}

A idade é um fator de risco bem definido para diversas doenças neurodegenerativas (Brown et al., 2005; Mariani et al., 2005; Qiu, 2007; Farooqui e Farooqui, 2009; Muangpaisan et al., 2011). Tais doenças afetam a qualidade de vida dos idosos e causam sofrimento físico e psicológico diante da perda da capacidade funcional (Weintraub e Stern, 2005; Kato-Narita et al., 2011; Schenkman et al., 2011). As doenças neurodegenerativas são consideradas a principal causa de incapacidade na população idosa (Jorgensen et al., 2007; Snijders et al., 2007).

Segundo um relatório realizado em 2015 pelo National Institute of Neurological Disorders and Stroke (NINDS) do National Institutes of Healthy $(\mathrm{NIH})$, milhões de pessoas em todo o mundo são afetadas por algum tipo de doença neurodegenerativa, sendo a Doença de Parkinson (DP) uma das mais prevalentes. A DP afeta aproximadamente 1-2\% das pessoas com 65 anos ou mais (Healy et al., 2008; Bekris et al., 2010). As estimativas do NIH (2015) sugerem que cerca de 50.000 americanos são diagnosticados com DP cada ano, embora algumas estimativas relatem prevalências maiores. Obter uma 
estimativa precisa do número de casos é difícil, porque nos estágios iniciais da doença muitas pessoas atribuem os seus sintomas ao envelhecimento normal e não procuram atendimento médico (Mittel, 2003; NIH, 2015).

Neuropatologicamente a DP é caracterizada pela progressão anatômica não randômica associada à perda neuronal, por depósitos de agregados proteicos anormais intracelulares e por um padrão de vulnerabilidade seletiva característico (Dickson 2007; Double et al., 2010; Grinberg et al., 2011). Até o momento, pouco se sabe sobre a associação entre a deposição de proteínas e a perda neuronal.

Embora muitas regiões do encéfalo exibam os sinais neuropatológicos da DP, a perda de células na substância negra é, frequentemente, considerada como sendo a característica neuropatológica mais importante (Gibb, 1991; Gibb e Lees, 1991; Damier et al. 1999b; Zecca et al., 2002; Braak et al., 2004; Double, 2012), representando um critério cardinal para o diagnóstico da DP (Figura 03). No entanto, até o momento, não se sabe por que certas regiões, como a substância negra, são vulneráveis enquanto outras populações neuronais vizinhas e, às vezes, morfologicamente indistinguíveis podem permanecer preservadas por anos e até décadas (Double et al., 2010).
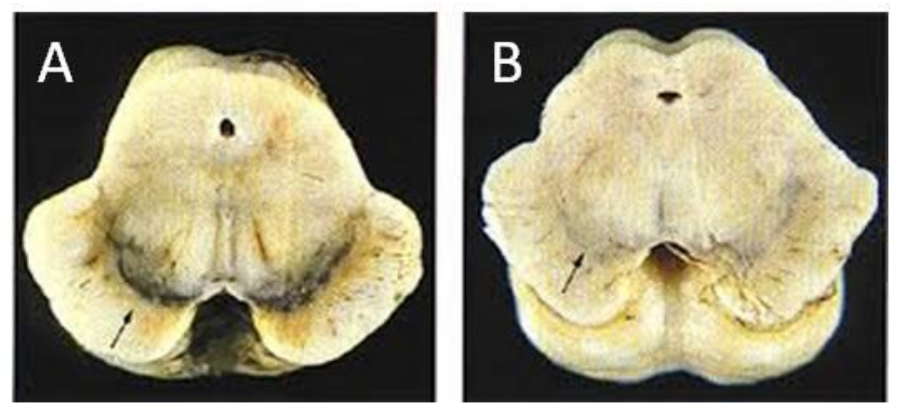

Figura 03. Fotografia da substância negra em indivíduos normais (A) e portadores de doença de Parkinson onde se observa a perda de coloração da substância negra (B). Modificado de Winkler, 2014.

\subsection{Substância Negra}


A Substância Negra (SN) é uma estrutura mesencefálica em formato oval achatada localizada no aspecto dorsal do pedúnculo cerebral que pode ser identificada anatomicamente através de um plano de corte sagital e/ou horizontal (Figura 04), devido à presença de um pigmento escuro.
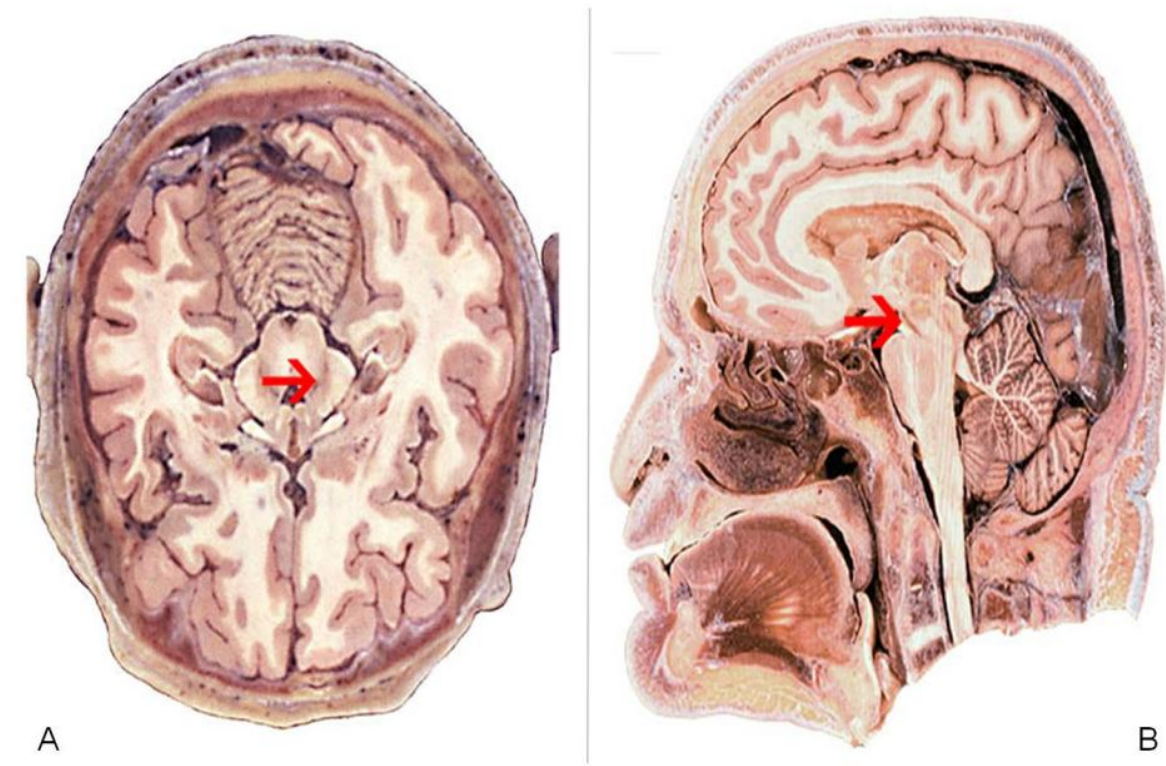

Figura 04. Localização da substância negra em um plano de corte horizontal (A) e sagital (B). Retirado de: www.thehumanbrain

Braak e Braak em 1986 identificaram três territórios na SN: pars compacta (SNpc), pars reticulata (SNpr) e pars diffusa (SNpd) e definiram três tipos de neurônios (Figura 05), baseados na forma, grau de pigmentação, tipos de processos celulares e tamanho:

Neurônios do tipo I: encontrados principalmente na pars compacta. Esses neurônios têm aproximadamente $50 \mu \mathrm{m}$ de diâmetro, são fusiformes ou poligonais, com 2 a 6 dendritos finos e esparsos que ocasionalmente se ramificam. Eles contêm um grande número de grânulos de neuromelanina e corpúsculos de Nissl na porção periférica que se estendem para a região proximal dos dendritos.

Neurônios do tipo II: encontrados principalmente na pars reticulata. Eles variam em tamanho e forma, embora sejam menores quando comparados aos neurônios do tipo I. Células bipolares e bastante alongadas são 
frequentemente verificadas, mas multipolares também podem ser encontradas. O número de dendritos primários depende do formato do corpo celular e o diâmetro desta célula é de aproximadamente $34 \mu \mathrm{m}$. Este tipo celular não apresenta depósitos de neuromelanina, porém um considerável número destes neurônios possuem grânulos de lipofucsina.

Neurônios do tipo III: são geralmente pequenos, com aproximadamente $16 \mu \mathrm{m}$ de diâmetro. Alguns finos dendritos se originam da superfície do neurônio e irradiam em várias direções. Os dendritos não possuem espinhas, e dão origem a alguns prolongamentos. Contêm grânulos de lipofucsina que são menores quando comparados aos grânulos de neuromelanina dos neurônios do tipo I e aos grânulos de lipofucsina dos neurônios do tipo II.

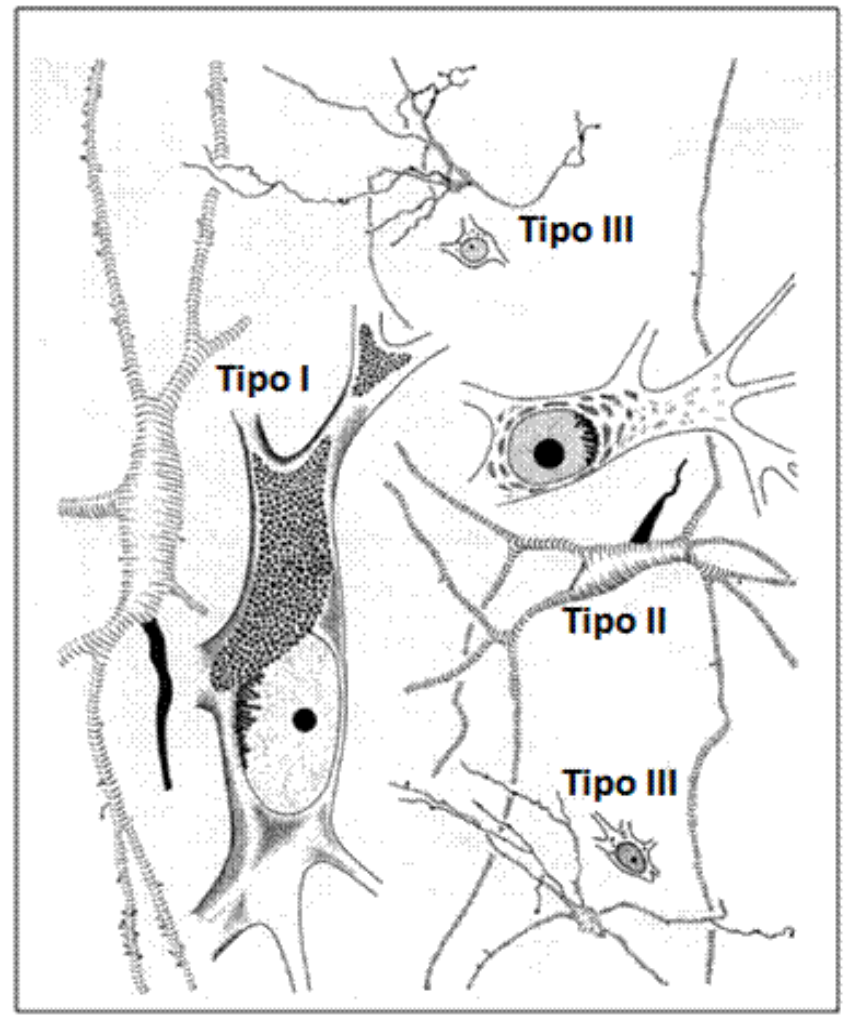

Figura 05. Diagrama dos tipos neuronais na substância negra. Modificado de Braak e Braak, 1986

Adicionalmente, a SN é composta por populações distintas de neurônios dopaminérgicos e GABAérgicos. As populações de neurônios GABAérgicos e dopaminérgicos são encontrados na pars reticulata (SNpr) e na pars compacta da SN (SNpc) respectivamente (Double et al., 2010). 
As células dopaminérgicas da pars compacta projetam-se principalmente para o estriado, bem como para o núcleo subtalâmico, globo pálido e para a pars reticulata (Cossette et al., 1999; Tepper e Lee, 2007). A SNpc recebe projeções de diferentes regiões encefálicas, como estriado, globo pálido (Tepper e Lee, 2007), pars reticulata (Tepper et al., 1995), entre outros. Um resumo esquemático dessas conexões bem como seus neurotransmissores, pode ser consultado na Figura 06.

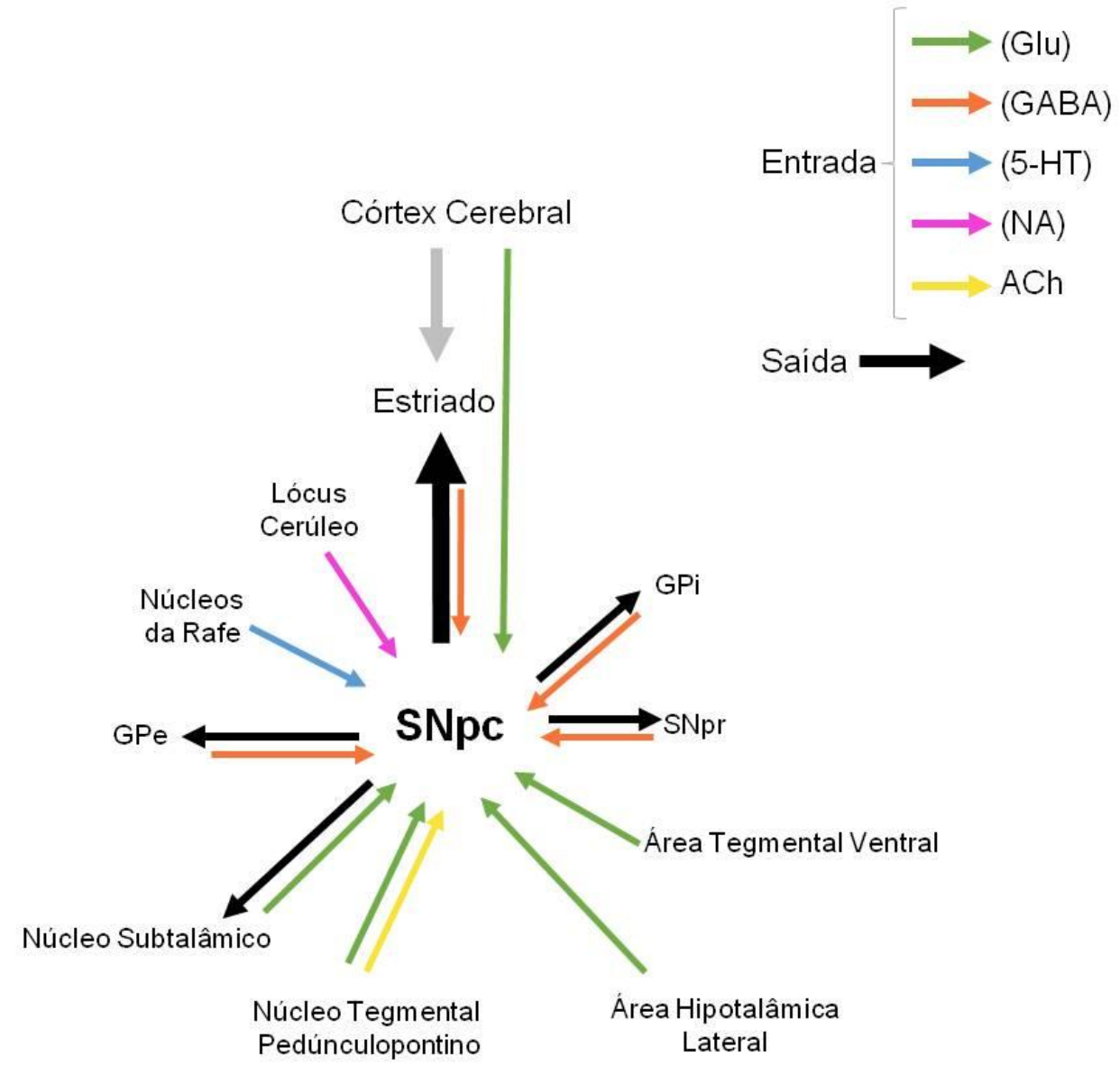

Figura 06: Modelo esquemático das conexões sinápticas dos neurônios da substância negra pars compacta (SNpc). Os neurotransmissores envolvidos Glu (Glutamato), GABA (Ácido Gama-Aminobutírico), 5-HT (5hidroxitriptamina), NA (Noradrenalina), Ach (Acetilcolina) estão indicados por diferentes cores de setas. Abreviações: SNpr (Substância Negra pars reticulata), GPe (Globo Pálido externo), GPi (Globo Pálido interno). Adaptado de Guatteo et al., 2009. 
No mesencéfalo, além da SNpc, outras duas regiões possuem neurônios dopaminérgicos: a área tegmental ventral e o campo retrorubral. Essas três regiões constituem o grupo mais proeminente de células dopaminérgicas cerebrais, aproximadamente $90 \%$ do total, sendo considerada a maior fonte de dopamina no sistema nervoso central dos mamíferos (Chinta, 2005; Gardaneh, 2010). Outras regiões onde se encontram neurônios dopaminérgicos são 0 diencéfalo e o bulbo olfatório. Apesar de possuírem 0 mesmo neurotransmissor, essas regiões são anatômica e funcionalmente heterogêneas (Chinta, 2005).

A SNpc pode ser dividida em uma série de sub-regiões, sendo que a definição e terminologia destas sub-regiões variam de autor para autor. Utilizando uma combinação de fatores anatômicos e neuroquímicos, alguns autores definiram quatro regiões: parte medial (também referido como o grupo ventromedial), parte lateral (também conhecida como nigrosomes 3), dorsal (também referida como nigrosomes 4, 5 e a matriz) e ventral (também referida como nigrosomes 1 e 2) (McRitchie et al., 1996; Damier et al., 1999a).

A degeneração dos neurônios dopaminérgicos é responsável pelos sintomas clássicos da DP e surgem quando houve aproximadamente $60-70 \%$ de perda neuronal (Hodge e Butcher, 1980; Marié e Defer, 2003; McAauley, 2003; Obeso et al., 2014). Em condições fisiológicas, indiretamente esses neurônios tem uma função importante no controle do movimento voluntário (Chinta e Andersen, 2005).

Alguns autores sugerem que a degeneração encontrada na DP afeta, principalmente, a camada ventral (aproximadamente $70-90 \%$ de perda neuronal) em comparação com o dorsal (25-70\% de perda neuronal) (Fearnley e Lees, 1991; Hirsch et al., 1997; Damier et al., 1999b; Obeso et al., 2014) (Figura 07). 


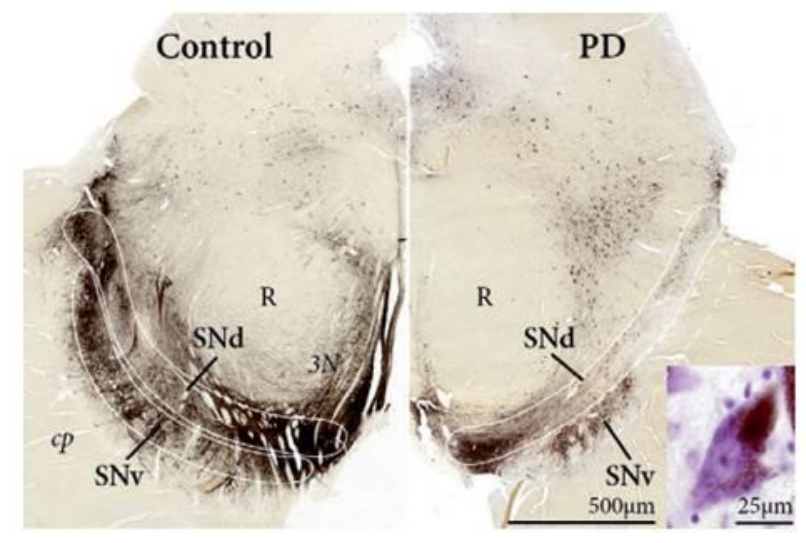

Figura 07. Representação do mesencéfalo através de um plano de corte horizontal. Do lado esquerdo a substância negra saudável, e do lado direito a substância negra na DP. Nota-se o diferente padrão de vulnerabilidade entre as camadas da substância negra. Modificado de Double, 2012.

Uma característica importante dos neurônios dopaminérgicos da substância negra humana é a presença do polímero neuromelanina. A neuromelanina começa a acumular-se dentro dos neurônios a partir dos 3 anos de idade (Cowen, 1986) e esse processo continua ao longo da vida (Zucca et al., 2014). Alguns estudos mostraram que o número de neurônios pigmentados diminui com a idade (McGeer et al., 1977; Fearnley e Lees, 1991) enquanto outros afirmam não haver perda dependente da idade (Muthane et al., 1998; Kubis et al., 2000).

A neuromelanina é produzida por neurônios catecolaminérgicos em três regiões do encéfalo humano: substância negra, lócus cerúleo e formação reticular (Fedorow, et al., 2005) (Figura 08). 


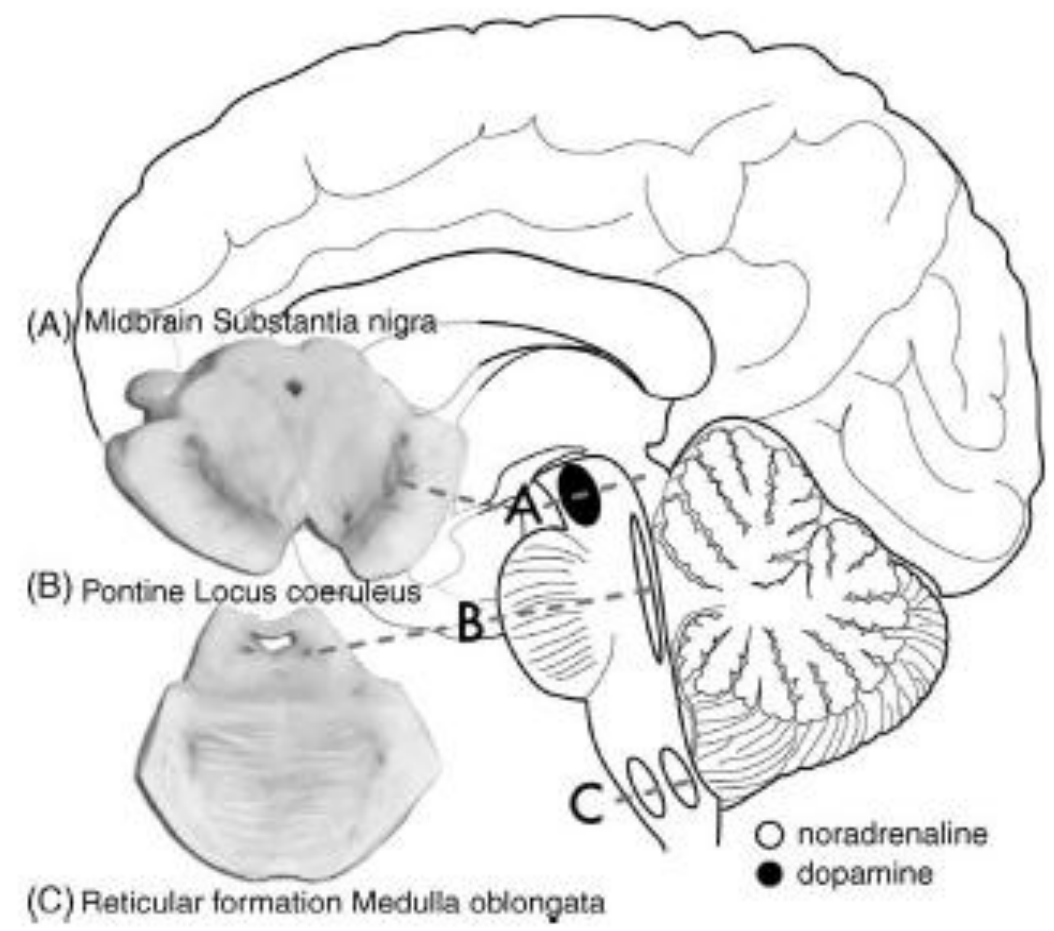

Figura 08. Regiões encefálicas contendo células produtoras de neuromelanina: (A) substância negra - mesencéfalo (B) locus coeruleus - ponte (C) formação reticular - bulbo. Modificado de Fedorow et al., 2005

Vários estudos têm sido realizados com o objetivo de compreender melhor o papel da neuromelanina no envelhecimento normal e no processo neurodegenerativo (Lindquist et al., 1987; Fasano et al., 2006; Bisaglia et al., 2009; Zhang et al., 2013). Uma hipótese é a de que a neuromelanina desempenhe um papel protetor, evitando danos de substâncias nocivas como, íons metálicos redox-ativos, toxinas e excesso de catecolaminas citosólicas às células (Zucca et al., 2004; Zucca et al., 2014). No entanto, também tem sido demonstrado um potencial tóxico para neuromelanina atuando como ativadora da micróglia endógena e, por consequente, causando inflamação (Zhang et al., 2013). Outra hipótese seria de que a neuromelanina em excesso poderia inibir a função do proteassoma (Shamoto-Nagai et al., 2004).

Segundo Karlsson e Lindquist (2013) a ligação de tóxicos a neuromelanina, inicialmente protege as células, mas como tal ligação é reversível, ela poderia provocar o acúmulo e consequente liberação do produto tóxico gradualmente no citosol. Apesar de inúmeras e diferentes hipóteses 
terem sido propostas, até então, não está clara a sua função no encéfalo humano.

Para preencher esta lacuna no conhecimento sobre a etiologia, os mecanismos da DP e a função da neuromelanina no encéfalo humano é de grande relevância o desenvolvimento de estudos topográficos mais focalizados - que permitam isolar populações específicas de neurônios, ao invés da análise de grandes estruturas e homogenados - preferencialmente associados à análises bioquímicas de ponta. Uma maneira eficiente de fazer isto é aplicar as ferramentas da dissecção a laser e proteômica em amostras bem caracterizadas de tecido humano cerebral.

\subsection{Microdissecção e captura a laser e a proteômica}

A técnica de Microdissecção e Captura a Laser (MCL) foi desenvolvida em 1996, por pesquisadores do National Cancer Institute dos EUA (EmmertBuck et al., 1996) e tornou-se amplamente utilizada como uma ferramenta na pesquisa biomédica, potencializando o uso de técnicas já existentes.

A MCL permite a aquisição de populações puras de células ou tecidos de determinadas regiões microscópicas. Atualmente, existem dois tipos de laser para realizar a MCL: infravermelho (IV) e ultravioleta (UV). Eles compartilham princípios fundamentais comuns: visualização e seleção da área a ser microdissecada através de um microscópio, transmissão de laser para excisar as células selecionadas, mecanismo que permite a catapultagem, ou seja, o lançamento da amostra e a presença de um tubo que capta a região alvo (Chung e Shen, 2015).

A MCL tem a vantagem de poder ser adaptada a uma diversidade de tipos celulares e métodos de coloração, tais como violeta de cresila (Bevilacqua et al., 2010), hematoxilina e eosina (Xu et al., 2002), imuno-histoquímica (He et al., 2013), imunofluorescência (Murakami et al., 2000), entre outros que facilitam a visualização histológica (Chung e Shen, 2015). O tecido a ser microdissecado pode ser fixado em formalina e embebido em parafina, pode 
ser espécimes congelados, cultura de células e preparações citológicas, como, esfregaços ou células citocentrifugadas (Curran e Murray, 2002; Guo et al., 2007; Rodriguez et al., 2008; Chowdhuri et al., 2012; Mustafa et al., 2012; Mukherjee et al., 2013; Chung e Shen, 2015).

Tal técnica reduz a probabilidade de contaminação, possui baixo contato de manipulação e evita problemas relacionados à heterogeneidade do tecido (Emmert-Buck et al., 1996; Murray e Curran, 2005; Murray, 2007; Vogel, 2007; Pietersen et al., 2011). Este fato é particularmente relevante para o tecido encefálico, que consiste em vários tipos celulares morfologicamente e/ou neuroquimicamente distintos cercados por vários tipos de células, como por exemplo, células gliais (oligodendrócitos, microglia e astrócitos). Portanto, a capacidade de isolar populações de células específicas, como por exemplo, neurônios surgiu recentemente como uma alternativa promissora (Banks et al., 1999; Craven e Banks, 2001; Moulédous et al., 2003; Caudle et al., 2008; Boone et al., 2013; Kumar et al., 2013) e unido a técnicas moleculares, pode acentuadamente melhorar a compreensão de diversos processos biológicos (Kummari et al., 2015).

A MCL tem sido cada vez mais utilizada em diversas áreas de pesquisa biomédica e suas aplicações nestas áreas são baseadas principalmente em biologia molecular, como a genética e proteômica (Kerk et al., 2003; Chung e Shen, 2015; Sethi et al., 2015). A combinação da MCL e técnicas proteômicas podem fornecem uma visão valiosa sobre possíveis caminhos e mecanismos envolvidos na patogênese de diversas doenças neurodegenerativas (Standaert, 2005; Chung e Shen, 2015; Sethi et al., 2015). No entanto, apesar das inúmeras vantagens oferecidas pela $\mathrm{MCL}$, este método ainda não foi amplamente incorporado no campo da neurociência.

A proteômica baseada em espectrometria de massas fundamentalmente modificou o modo como os sistemas biológicos são estudados. Essa técnica permite a análise de milhares de proteínas, incluindo os diversos processos relacionados à sua função (Farley e Link, 2009) tais como, a localização específica, as interações proteína-proteína, o "turnover" e as modificações póstraducionais (PTMs) (Aebersold e Mann, 2003; Altelaar et al., 2013). 
A técnica de espectrometria de massas identifica analitos que foram purificados e/ou fracionados por cromatografia. A cromatografia pode estar acoplada ao espectrômetro de massas e o uso desta alternativa vem crescendo de forma exponencial. Vários tipos podem ser utilizados, como por exemplo, Cromatografia Gasosa (CG) ou Cromatografia Líquida (CL). A cromatografia líquida de alta eficiência, do inglês High Performance/Pressure Liquide Chromatography (HPLC) é o método de CL mais comum de separação. Neste tipo, o analito passa por dois processos: I) fase líquida, onde a amostra é dissolvida e II) fase estacionária, geralmente constituída de uma ou várias colunas com diferentes fases estacionárias compostas de materiais porosos e filtros (Wuhrer, 2009).

A espectrometria de massas, do inglês Mass Spectrometry (MS) consiste basicamente na ionização de um composto e na avaliação da razão de massa/carga (m/z) dos íons (Hoffmann, 1996; Ho et al., 2003). O equipamento é composto de uma fonte de ionização, um ou mais analisadores de massas e um detector, conectado a um computador contendo softwares específicos para as análises dos dados.

Existem dois principais métodos de ionização, o MALDI (Matrix-Assisted Laser Desoption/Ionization) usado para amostras em estado sólido e o ESI (Electrospray lonization) utilizado para amostras em estado líquido. As fontes de ionização são utilizadas para gerar íons peptídicos ou proteicos, através de transferência de prótons $\left(\mathrm{H}_{+}\right)$para as moléculas, sem alterar sua estrutura química (Ho et al., 2003; Hommerson et al., 2011).

No analisador, o íon é acelerado em campo elétrico, separado pela razão $\mathrm{m} / \mathrm{z}$. O íon pode ainda ser selecionado de acordo com a m/z previamente determinada e fragmentado através de um processo chamado MassSpectrometry/Mass-Spectrometry (MS/MS) ou espectrometria de massas em tandem. Os analisadores de massa podem ser do tipo: Time Of Flight (TOF); quadrupolo ou Ion Trap (IT) (Louris et al., 1987; Adahchour, 2005; Chen et al., 2010). Independentemente do tipo, nos analisadores a massa molecular dos íons é avaliada. 
O exemplo do HPLC acoplada ao espectrômetro de massas bem como, o diagrama de espectrometria de massas em tandem (MS/MS) pode ser consultado na Figura 09.

A
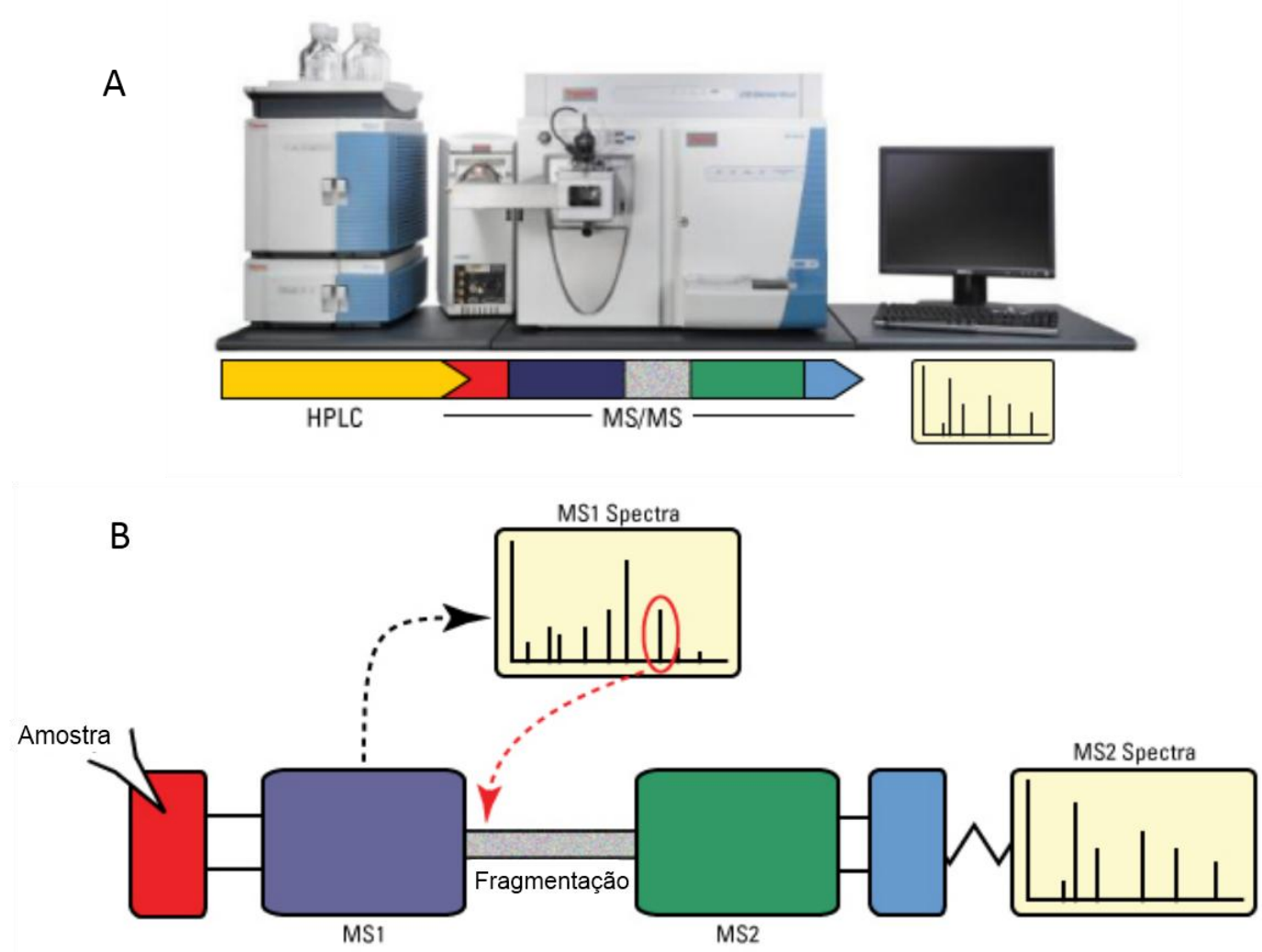

Figura 09. (A) exemplo do sistema de HPCL acoplado ao espectrômetro de massas (B) diagrama de espectrometria de massas em tandem. A amostra é injetada no espectrômetro de massas, ionizado e acelerado. Em seguida, são analisados (MS1). Os íons dos espectros MS1 são seletivamente fragmentados e novamente analisados por espectrometria de massas (MS2). Modificado de Thermo Scientific, 2014.

Enquanto a identificação de proteínas é importante para entender os processos biológicos, a análise direta das proteínas em amostras obtidas a partir da técnica de microdissecção a laser é de grande relevância, pois reduz a complexidade do cérebro ao permitir a obtenção de áreas ou células específicas.

A literatura, ainda carece de descrições sobre metodologias e padronizações utilizando eficientemente essas duas técnicas. Diante deste e 
de outros questionamentos, nós propomos e testamos um protocolo para a realização da MCL baseado em outros trabalhos publicados previamente (Emmert-Buck et al., 1996; Fend e Raffeld, 2000; De Souza et al., 2004; Cummings et al., 2011; Sturm, et al., 2012). Nosso foco foram os neurônios da pars compacta da substância negra de encéfalos humanos para posteriores análises proteômicas. Foram utilizados utilizando casos clinica e neuropatologicamente normais provenientes da casuística do Banco de Encéfalos Humanos do Grupo de Estudos em Envelhecimento Cerebral da Faculdade de Medicina da Universidade de São Paulo (BEHGEEC-FMUSP), criado em 2003 com o objetivo de contribuir com o estudo do envelhecimento cerebral e melhor entendimento dos processos relacionados à senescência e à senilidade cerebral (Ferretti et al., 2009). Nós optamos por utilizar casos cognitivamente normais, pois a criação de uma base normativa é extremamente importante antes que se queira compreender o processo patológico. As investigações ao nível proteico têm contribuído para ajudar a identificar, caracterizar e entender essas diferenças e tem sido cada vez mais utilizadas (Urquhart et al., 1997; Watarai et al., 2000; Zhou et al., 2002; Tribl et al., 2005; Alberio et al., 2010). Além disso, podem permitir a identificação de alvos para o diagnóstico precoce e tratamento da doença (Liao et al., 2004; Kitsou et al., 2008).

Os resultados desse trabalho podem ser aplicados em outras propostas de estudo utilizando tecido encefálico, já que o estabelecimento de um protocolo padronizado é crucial para o sucesso de qualquer experimento no campo da proteômica (González-Fernández et al., 2010). 
2. OBJETIVOS 
I. Estabelecer um protocolo para a realização da MCL em tecido cerebral humano e subsequente análise proteômica;

II. Validar este protocolo por meio da $\mathrm{MCL}$ e análise proteômica em neurônios contendo neuromelanina na substância negra de indivíduos sem alterações clínicas e neuropatológicas. 
3. MATERIAIS E MÉTODOS 


\subsection{Procedência dos casos}

A Comissão de Ética em Pesquisa da Faculdade de Medicina da Universidade de São Paulo (FMUSP) aprovou o protocolo de pesquisa do presente estudo (no 361/10), apresentado pelo Departamento de Patologia. O termo de aprovação está apresentado no Anexo $(\mathrm{A})$.

Este projeto conta com a colaboração do Centro de Proteômica Médica da Universidade de Bochum, Alemanha, aprovado pelo Comitê Nacional de Ética em Pesquisa - CONEP sob o registro № 16380 conforme o Anexo (B).

Os casos selecionados para o presente estudo são pertencentes a casuística do BEHGEEC.

\subsection{Procedimentos do BEHGEEC}

Os casos incluídos no BEHGEEC são provenientes de autópsias realizadas no Serviço de Verificação de Óbitos da Capital (SVOC). O SVOC realiza as autópsias em indivíduos que tenham falecido de morte natural ou indivíduos em que, a causa de morte não foi definida em vida. No Brasil, o serviço de autópsia é mandatório para os casos de óbitos de causa mal definida.

Na chegada do cadáver ao SVOC, as famílias devem comparecer ao serviço para reclamação do corpo e sua liberação para que então, sejam iniciados os procedimentos de autópsia. Os procedimentos de autópsia e a liberação dos documentos duram em média 3 horas (Grinberg et al., 2007).

Caso o indivíduo atenda aos critérios de seleção do BEHGEEC, os familiares, presentes no SVOC, são convidados a participar do estudo. Nesse momento, são explicados os objetivos do estudo, sua relevância e todos os procedimentos de pesquisa pretendidos. Após consentimento informado, um 
membro da família assina, voluntariamente, o Termo de Consentimento Livre e Esclarecido e o caso é então incluído no estudo. Os procedimentos do estudo são realizados apenas após a autorização do responsável, mediante a assinatura do Termo de Consentimento Livre e Esclarecido (Ferreti et al., 2009).

\subsubsection{Critérios de seleção do BEHGEEC}

- Ter idade, na data do falecimento, igual ou maior a 50 anos;

- Possuir um familiar responsável ou cuidador, com contato mínimo semanal durante os seis meses anteriores ao óbito;

- Possuir um informante (familiar responsável ou cuidador) capaz de prestar informações consistentes a respeito do histórico de saúde do sujeito;

- Não ser portador de doenças cerebrais que impossibilitem a avaliação macroscópica cerebral, como acidente vascular encefálico hemorrágico;

- Não ser portador de doença avançada no período de três meses anteriores à morte, responsáveis por causar hipóxia ou hipofluxo cerebral;

- Não possuir história de parada cardiorespiratória prolongada nos três meses anteriores ao óbito;

- Não possuir pH do líquido cefalorraquidiano menor que 6,5 indicando acidose grave devido ao estado agonal.

\subsubsection{Avaliação Clínica}

Durante o procedimento de autópsia, a avaliação clínico-funcional do indivíduo é realizada através de uma entrevista clínica semiestruturada. 0 responsável indicado por relatar as informações pode ser um familiar, um cuidador, ou alguém que tenha tido um contato próximo com o sujeito por pelo 
menos seis meses anteriores ao óbito, de modo que, as informações possam ser confiáveis.

Os indivíduos são entrevistados de segunda a sexta-feira, em uma sala privada, por uma equipe de entrevistadores treinados e supervisionados por um enfermeiro gerontólogo (Grinberg et al., 2007). Durante a entrevista, o entrevistador julga se as informações obtidas são confiáveis com o objetivo de decidir se o caso será ou não incluído no estudo. O gerontólogo é responsável por revisar a entrevista após o término para avaliar a consistência dos dados coletados. Posteriormente essas entrevevistas são discutidas em uma reunião de consenso diagnóstico por uma equipe de médicos (especialistas em neurologia e geriatria) e enfermeiros gerontólogos (Ferretti et al., 2009).

O protocolo de coleta de dados consiste em uma série de escalas e questionários validados, cuja função é avaliar os aspectos cognitivos, comportamentais, funcionais e socioeconômicos, bem descritos e utilizados mundialmente (Grinberg et al., 2007; Ferretti et al., 2009). Para a avaliação global do domínio cognitivo é utilizado o questionário Clinical Dementia Rating (CDR) descrito por Morris (1993). O protocolo de entrevista completo pode ser consultado no Anexo C.

\subsubsection{Processamento do encéfalo}

Após a abertura da calota craniana durante o procedimento de autópsia são realizados os seguintes procedimentos: I) coleta do líquido cefalorraquidiano, para posterior aferição do $\mathrm{pH}$; II) coleta de sangue para estudos bioquímicos e genéticos; III) aferição do volume do encéfalo pelo método de Arquimedes; IV) aferição da massa do encéfalo em balança digital.

Em seguida o encéfalo é levado para a sala de procedimentos no laboratório do BEHGEEC dentro de um saco zip imerso em uma cuba com gelo e água refrigerada para conservação do tecido. Um conjunto de 17 regiões é representado e congelado a temperatura de $-80^{\circ} \mathrm{C}$. Essas amostras eventualmente serão utilizadas para procedimentos bioquímicos e genéticos. 
O hemisfério contralateral é fixado em formol a $4 \%$ tamponado com fosfato de potássio $(\mathrm{pH}=7,4)$ por no máximo 15 dias. Durante 0 processamento, também é verificado se há presença de lesões vasculares. Após esse período, o material encefálico é seccionado em intervalos de $1 \mathrm{~cm}$ e um conjunto mínimo de 19 áreas são amostradas, sendo posteriormente embebidas em blocos de parafina para o diagnóstico neuropatológico.

As regiões amostradas e os respectivos procedimentos abordados pelo protocolo do BEHGEEC estão descritas na Tabela 01.

\begin{tabular}{|c|c|c|}
\hline Áreas Encefálicas Amostradas & $\begin{array}{l}\text { Embebidos } \\
\text { em parafina }\end{array}$ & $\begin{array}{c}\text { Armazenados } \\
\text { a }-80^{\circ} \mathrm{C} \\
\end{array}$ \\
\hline Amígdala e córtex entorrinal & $x$ & $\mathrm{x}$ \\
\hline Bulbo olfatório & $x$ & $\mathrm{X}$ \\
\hline Cerebelo incluindo o núcleo denteado & $x$ & $\mathrm{X}$ \\
\hline Centro semi oval & $x$ & \\
\hline Formação hipocampal anterior & $x$ & \\
\hline $\begin{array}{l}\text { Hipocampo na altura do corpo geniculado lateral e } \\
\text { giro temporal inferior }\end{array}$ & $x$ & $\mathrm{X}$ \\
\hline Hipocampo contra lateral & $x$ & \\
\hline $\begin{array}{l}\text { Núcleo basal incluindo o núcleo basal de Meynert, na } \\
\text { altura da comissura anterior }\end{array}$ & $\mathrm{X}$ & \\
\hline Giro do cíngulo & & $x$ \\
\hline Giro frontal médio & $x$ & $x$ \\
\hline Giro frontal superior e giro do cíngulo & $x$ & \\
\hline Giro orbitofrontal & & $x$ \\
\hline Giro parahipocampal & & $\mathrm{X}$ \\
\hline Giro temporal médio e superior & $\mathrm{x}$ & $\mathrm{X}$ \\
\hline Lóbulo parietal inferior e superior & $x$ & $\mathrm{x}$ \\
\hline Medula Oblonga & $\mathrm{x}$ & \\
\hline Mesencéfalo incluindo substância negra & $\mathrm{x}$ & \\
\hline Plexo coróide & $x$ & $\mathrm{x}$ \\
\hline Ponte incluindo o lócus cerúleo & $x$ & \\
\hline Sulco calcarino (área visual primária) & $\mathrm{x}$ & $\mathrm{x}$ \\
\hline Tálamo & $x$ & \\
\hline $\begin{array}{l}\text { Território de transição entre as artérias cerebrais } \\
\text { anterior e média }\end{array}$ & $\mathrm{X}$ & \\
\hline $\begin{array}{l}\text { Território de transição entre as artérias cerebrais } \\
\text { média e posterior }\end{array}$ & $x$ & \\
\hline
\end{tabular}

Tabela 01. Regiões amostradas pelo protocolo do BEHGEEC.

Adaptado de Grinberg et al., 2007 


\subsubsection{Diagnóstico neuropatológico}

Os fragmentos encefálicos embebidos em parafina são seccionados em espessura de $5 \mu \mathrm{m}$ e colocados em lâminas silanizadas (3-Aminopropil-trietoxisilano) para a coloração de Hematoxilina e Eosina (HE) e aplicação do protocolo de imuno-histoquímica.

A imuno-histoquímica de rotina é realizada usando anticorpos contra os seguintes peptídeos ou proteínas: $\beta$-amilóide, tau hiperfosforilada, $\alpha$-sinucleína e TDP-43. O método utilizado é avidina-biotina por imunoperoxidase, a revelação é feita através do cromógeno 3,3'-diaminobenzidina e a contracoloração através de hematoxilina de Harris. As áreas imunocoradas e respectivos anticorpos estão demonstrados na Tabela 02.

\begin{tabular}{|c|c|c|c|c|}
\hline Região do encéfalo & $\begin{array}{c}\text { Contra } \\
\text { Proteína } \\
\text { Amilóide }\end{array}$ & $\begin{array}{c}\text { Contra } \\
\text { Proteína } \\
\text { Tau }\end{array}$ & $\begin{array}{l}\text { Contra } \\
\text { Proteína } \alpha- \\
\text { sinucleína }\end{array}$ & $\begin{array}{c}\text { Contra } \\
\text { Proteína TDP } \\
43\end{array}$ \\
\hline $\begin{array}{l}\text { Giros frontais médio e } \\
\text { inferior }\end{array}$ & $x$ & $\mathrm{x}$ & & \\
\hline $\begin{array}{l}\text { Giros temporais superior e } \\
\text { médio }\end{array}$ & $x$ & $\mathrm{x}$ & & $x$ \\
\hline $\begin{array}{l}\text { Hipocampo, na altura do } \\
\text { corpo geniculado lateral e } \\
\text { giro parahipocampal } \\
\text { adjacente }\end{array}$ & $x$ & $\mathrm{x}$ & $\mathrm{x}$ & $x$ \\
\hline Amigdala e córtex adjacente & $x$ & $x$ & $x$ & $x$ \\
\hline $\begin{array}{l}\text { Mesencéfalo com substância } \\
\text { negra }\end{array}$ & $\mathrm{x}$ & $x$ & $x$ & \\
\hline $\begin{array}{l}\text { Núcleos da base, na altura } \\
\text { da comissura anterior }\end{array}$ & $x$ & & & \\
\hline Ponte com locus ceruleus & & & $x$ & \\
\hline Bulbo na altura da oliva & $x$ & & $x$ & \\
\hline Cerebelo & $x$ & & & \\
\hline Bulbo olfatório & & & $x$ & \\
\hline
\end{tabular}

Tabela 02. Áreas imunocoradas e anticorpos rotineiramente utilizados no BEHGEEC. Adaptado de Grinberg et al., 2007 
O exame anatomopatológico é realizado por neuropatologista cego a todos os dados clínicos obtidos. São utilizados critérios mundialmente aceitos para o diagnóstico de doenças neurodegenerativas (Braak e Braak 1991; Mirra 1996; Mckeith et al., 1997) e já descritos por trabalhos publicados pelo nosso grupo (Grinberg et al., 2007; Farfel et al., 2013).

\subsection{Critérios de seleção de casos para o presente estudo}

Além dos critérios de inclusão estabelecidos e descritos do BEHGEEC, para este trabalho, foram adotados os seguintes critérios:

- Não possuir declínio cognitivo de acordo com o questionário CDR;

- Não ser portador de nenhuma doença neurodegenerativa;

- Apresentar o tronco encefálico morfologicamente intacto.

Para este estudo, 8 casos foram selecionados. Destes, um foi excluído, visto que não apresentava o tronco encefálico morfologicamente intacto.

\subsection{Estabelecimento do protocolo para a realização da técnica de microdissecção e captura a laser}

Durante o processamento encefálico de rotina do BEHGEEC, descrito no item 3.2.3, o tronco encefálico foi separado do encéfalo na altura do tálamo (acima dos colículos superiores), seccionado sagitalmente, tendo como base 0 sulco mediano dorsal, e congelado.

A representação do mesencéfalo foi realizada com o tronco encefálico congelado. Na porção rostral, o tronco encefálico foi seccionado na altura dos colículos superiores. Na porção caudal, o tronco encefálico foi seccionado na altura da ponte (Figura 10). 


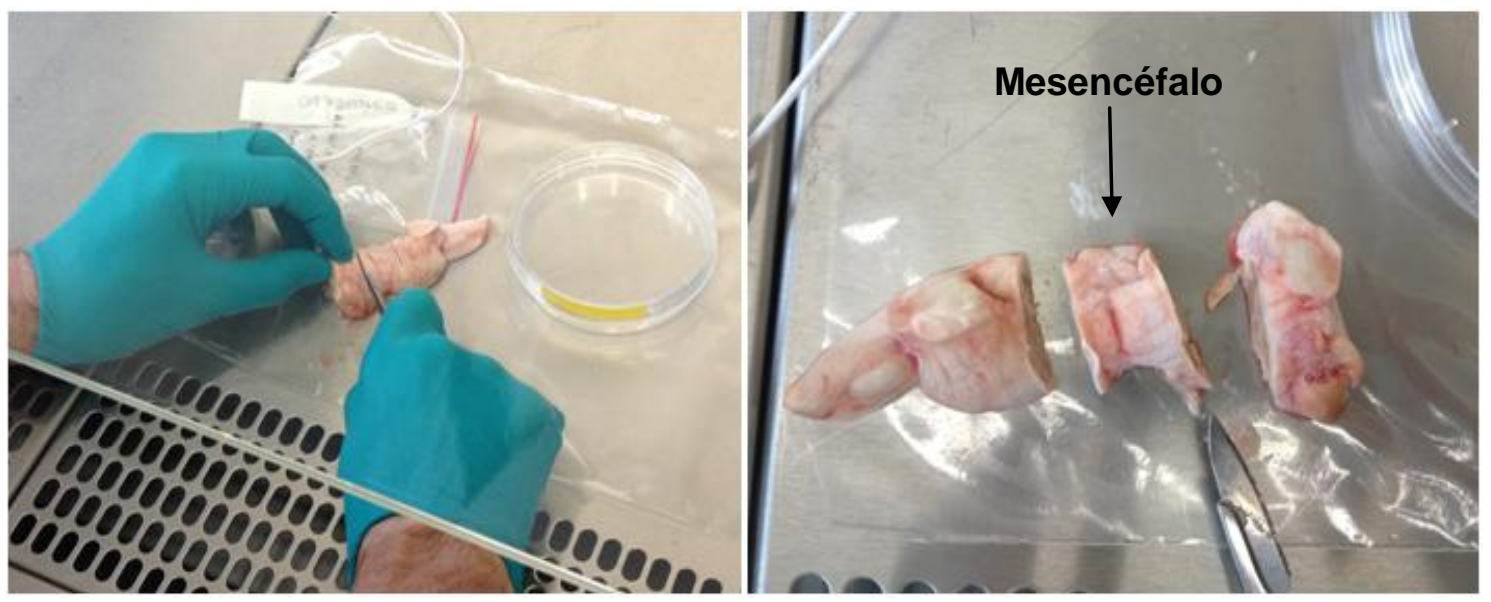

Figura 10. Procedimento do corte do tronco encefálico para a representação do mesencéfalo. Arquivo pessoal.

3.4.1 Definição do plano anatômico ideal para a coleta dos neurônios

Diferente do processamento encefálico abordado rotineiramente no protocolo do BEHGEEC, esta abordagem exigiu que o tronco encefálico de dois indivíduos cognitivamente normais fossem fixados por imersão em formalina a 10\% durante 4 semanas. Após esse período, o material foi desidratado em uma série graduada de soluções de etanol, embebidos em celoidina usando um método modificado, desenvolvido por Heinsen et al. (2000) e seccionados com uma espessura $350 \mu \mathrm{m}$.

Foram testados os planos horizontal e sagital. As lâminas foram coradas com galocianina (coloração de Nissl) e montadas com resina como previamente descrito por Heinsen e colaboradores em 1991. O arranjo e a densidade de células por fatia foram comparados na substância negra segundo o plano de corte em cada secção.

3.4.2 Definição do método de congelamento para MCL 
Para este tópico, mesencéfalos de três indivíduos diferentes foram selecionados e seccionados sagitalmente. Para essa abordagem, ambos os lados foram utilizados (direito e esquerdo) diferindo do protocolo proposto pelo BEHGEEC, resultando em 6 amostras. Três protocolos de com diferentes combinações de passos de congelação foram testados: I) congelação em freezer a $-20 \circ \mathrm{C}$ durante $30 \mathrm{~min}$, seguido de armazenamento a $-80^{\circ} \mathrm{C}$; II) congelamento e armazenamento a $-80^{\circ} \mathrm{C}$; e III) congelamento por inserção em nitrogênio líquido, seguido de armazenamento $-80^{\circ} \mathrm{C}$ (Tabela 03). Os casos foram cortados e corados com violeta de cresila. Três investigadores independentes e cegos para o método de congelação analisaram qualitativamente as fatias com base na morfologia dos neurônios e a qualidade do tecido.

\begin{tabular}{ccc}
\hline Caso & Lado & Procedimento \\
\hline \multirow{2}{*}{$\mathbf{1}$} & Esquerdo & $-20^{\circ} \mathrm{C} /-80^{\circ} \mathrm{C}$ \\
& Direito & $-80^{\circ} \mathrm{C}$ \\
2 & Esquerdo & $-20^{\circ} \mathrm{C} /-80^{\circ} \mathrm{C}$ \\
& Direito & Nitrogênio líquido $/-80^{\circ} \mathrm{C}$ \\
3 & Esquerdo & $-80^{\circ} \mathrm{C}$ \\
& Direito & Nitrogênio líquido $/-80^{\circ} \mathrm{C}$
\end{tabular}

Tabela 03. Visão geral dos procedimentos de congelação

3.4.3 Definição da espessura do corte, coloração do tecido e microdissecção a laser

O mesencéfalo de um indivíduo foi seccionado de acordo com o tópico 3.4. O tecido foi fixado por meio de resina do tipo Tissue-Tek (O.C.T - Optimal Cutting Temperature) em suporte de criostato. Posteriormente, foram realizadas secções em criostato (Modelo CM 1850 UV, Nußloch GmbH, Nußloch, Alemanha) a $-20^{\circ} \mathrm{C}$ de temperatura dentro da câmara (Figura 11). 

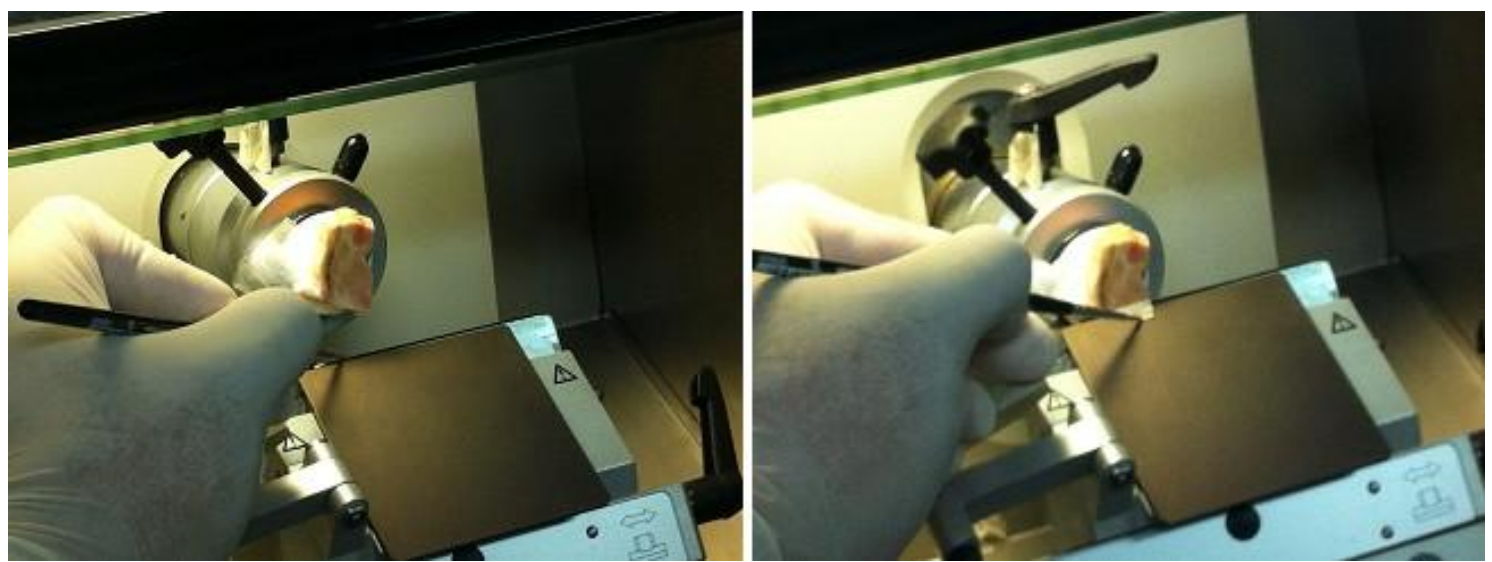

Figura 11. Procedimento de corte no criostato. Arquivo pessoal.

Antes do corte, o tecido foi mantido por 15 minutos dentro do criostato para estabilizar a temperatura. As secções foram colocadas em lâminas com membrana própria para MCL (PALM MembraneSlides $1 \mathrm{~mm}$ PEN, Carl Zeiss Microscopia $\mathrm{GmbH}$, Gottingen, Alemanha). Para distinguir as células, os cortes foram corados com violeta de cresila a $1 \%$ de acordo com o protocolo estabelecido pela Carl Zeiss Microscopy GmbH (Carl Zeiss Microlmaging, LCM Protocols - Protein Handling for LC/MS), com pequenas modificações. $O$ violeta de cresila é um corante básico, utilizado para evidenciar núcleos. Esta técnica de coloração é recomendada para microdissecção a laser destinada a subsequentes abordagens proteômicas (Chaurand et al. 2004; Caldwell e Caprioli, 2005). Para preparar a solução, 1 grama de violeta de cresila (Cresyl violet acetate, Sigma Life Sciences, St. Louis, EUA) foi diluída em $100 \mathrm{ml}$ de etanol a 50\% e agitada por 12 horas através de uma placa de agitação. No dia seguinte, a solução foi filtrada para remover possíveis partículas não dissolvidas. A solução foi mantida a $4^{\circ} \mathrm{C}$ até a sua utilização. O resumo do protocolo de coloração pode ser consultado na Tabela 04. 


\begin{tabular}{ccccc}
\hline Etapa & Solução & Procedimento & Duração & Temperatura \\
\hline 1. & Etanol $70 \%$ & Incubação & 2 min & $\mathbf{4}^{\circ} \mathbf{C}$ \\
2. & Violeta de Cresila & Incubação & $30 \mathrm{~s}$ & TA \\
3. & --- & Descartar excesso de & & \\
4. & Etanol $70 \%$ & corante & & \\
5. & Etanol $100 \%$ & Mergulhar & $3-5 \times 1 \mathrm{~s}$ & $\mathbf{4}^{\circ} \mathbf{C}$ \\
6. & --- & Mergulhar & $1 \times \mathrm{s}$ & $\mathbf{4}^{\circ} \mathbf{C}$ \\
\hline
\end{tabular}

$\mathrm{TA}=$ Temperatura Ambiente

Tabela 04. Procedimento de coloração com violeta de cresila

$\mathrm{Na}$ sequência foi realizada a MCL. O sistema de microdissecção a laser é composto por (1) um microscópio invertido; (2) uma fonte de raios laser, acoplada a porção posterior do microscópio cujo feixe atravessa 0 microscópio através da objetiva e atinge a lâmina; (3) um computador alimentado com um programa próprio, para controle das diversas funções do microscópio e do laser (Figura 12). O sistema informatizado permite controle direto de quase todas as atividades por computador, desde a observação dos cortes histológicos até a microdissecção em si. O software também possibilita calcular as áreas dos campos escolhidos.
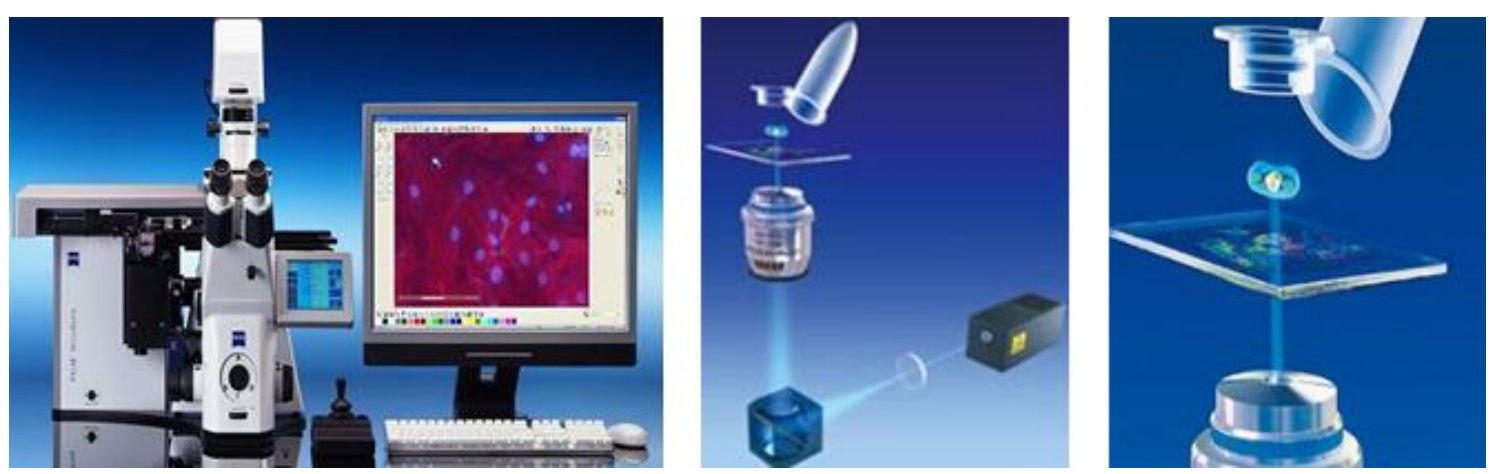

Figura 12. Imagem representativa do sistema PALM MicroBeam. Modificado de PALM MicroBeam Microdissection System to Research Platform - The New Standard in Modern Life Science Research. 
O pulso de laser transporta a amostra selecionada da lâmina para um dispositivo de coleta (geralmente a tampa de um microtubo, que deve conter um adesivo ou estar preenchido com uma solução).

Nesta abordagem, nós testamos duas soluções diferentes para a coleta do material: I) água ultrapura (TKA-Gene PURE, Thermo Scientific, Baltimore, USA) e II) solução a $50 \%$ de acetonitrila (Biosolve BV, Valkenswaard, Holanda) diluída em água.

A MCL foi realizada com o instrumento PALM MicroBeam (LCM PALMSystem, Carl Zeiss Microscopy, $\mathrm{GmbH}$ ). Para a padronização, a tampa do microtubo foi preenchido com $50 \mu \mathrm{l}$ de uma das soluções. Uma vez que o estabelecimento do protocolo incluiu a subsequente análise por espectrometria de massas, logo após de terminar a MCL, 2,5 $\mu$ l RapiGest ${ }^{\mathrm{TM}}$ Surfactante a $2 \%$ $(\mathrm{m} / \mathrm{v}$ ) (Waters $\mathrm{GmbH}$, Milford, MA, EUA) foi cuidadosamente adicionada na tampa do tubo de modo que a concentração final fosse de $0,1 \%(\mathrm{~m} / \mathrm{v})$ e que 0 processo de desnaturação das proteínas fosse iniciada. O tubo foi fechado e armazenado de cabeça para baixo a $-80^{\circ} \mathrm{C}$.

Durante o procedimento de microdissecção se não fosse possível a coleta de toda a amostra desejada em uma única lâmina a lâmina seguinte também era utilizada com intuito de evitar a evaporação desnecessária da solução presente na tampa do tubo.

Foram testadas 4 espessuras para o isolamento dos neurônios e regiões da SN: $5 \mu \mathrm{m} ; 10 \mu \mathrm{m} ; 20 \mu \mathrm{m}$ e $30 \mu \mathrm{m}$. A seleção da espessura ideal foi baseada na capacidade de catapultar a região/células e na capacidade de estabelecer os parâmetros do laser necessários para um processo de catapultagem eficaz dentro de um curto espaço de tempo.

\subsection{Otimização do protocolo de preparação das amostras para espectrometria de massas}

3.5.1 Preparação e digestão das amostras para análise por espectrometria de massas 
A digestão é necessária para que todas as partes da proteína fiquem uniformemente expostas à dissociação e ionização, bem como, para aumentar a eficiência desses processos. As proteases normalmente utilizadas são: quimotripsina, pepsina, carboxipeptidases, aminopeptidases, tripsina. A tripsina por exemplo, cliva resíduos de arginina ou lisina.

Para a digestão das amostras, os tubos com o tecido coletado foram incubados ainda de cabeça para baixo em banhos de ultrassons durante 1 minuto, em seguida as amostras foram centrifugadas brevemente. Esta etapa foi repetida. Posteriormente, as amostras foram incubadas a $95^{\circ} \mathrm{C}$ durante 5 min em um termomisturador e centrifugadas novamente. Um microlitro de 250 mM de 1,4-ditiotreitol (DTT, AppliChem GmbH, Darmstadt, Alemanha) foi adicionado em cada amostra e essa mistura foi incubada durante $30 \mathrm{~min}$ a $60^{\circ} \mathrm{C}$. Subsequentemente, as amostras foram novamente incubadas com $1,4 \mu \mathrm{l}$ de iodoacetamida a 0,55 M (AppliChem) em temperatura ambiente durante 30 min em câmara escura. A digestão foi iniciada por adição de 1:4 de tripsina diluída em água (Promega, Mannheim, Alemanha) durante 4 horas a $37^{\circ} \mathrm{C}$ e paralisadas com adição de 3,25 $\mu \mathrm{l}$ de ácido trifluoacético (TFA) a 10\% durante $30 \mathrm{~min}$ a $37^{\circ} \mathrm{C}$. As amostras novamente foram centrifugadas durante $15 \mathrm{~min}$ a $14.000 \mathrm{rpm}$ a $4^{\circ} \mathrm{C}$. O sobrenadante resultante foi transferido para uma nova tampa e seco com auxílio do SpeedDry (RVC 2-25 CDplus, Martin Christ Gefriertrocknungsanlagen $\mathrm{GmbH}$, Osterode, Alemanha). Finalmente, $30 \mu \mathrm{l}$ de TFA a $0,1 \%$ foram adicionados a cada amostra.

3.5.2 Determinação da concentração de proteína, com a análise de aminoácidos

Depois da digestão da amostra, as concentrações de proteína foram determinadas por análise de aminoácidos, como descrito por Plum et al. (2013). Para este processo, $5 \mu \mathrm{l}$ de cada amostra foi completamente seco em 
um tubo de vidro. Em seguida, as amostras foram dissolvidas pela adição de $10 \mu \mathrm{l}$ de de ácido clorídrico $(\mathrm{HCl})$ a $20 \mathrm{mM}$. A análise de aminoácidos foi realizada através de HPLC. De acordo com as instruções do fabricante, utilizando o HPLC Acquity e AccQ-Tag (Waters $\mathrm{GmbH}$ ). Para a derivação e para permitir a conversão de aminas primárias e secundárias em derivados estáveis, as amostras foram incubadas com $10 \mu \mathrm{l}$ de AccQ-Tag e $30 \mu \mathrm{l}$ norvalina padrão (concentração final: $10 \mathrm{pmol} / \mu \mathrm{l}$ ) durante $10 \mathrm{~min}$. Derivados de aminoácidos foram separados sobre uma coluna AccQ-Tag ultra RP (Reversed Phase) e detectado pelo Acquity UPLC-TUV (Ultra Performance Liquid Chromatography - Tunable UV Detector) (Waters $\mathrm{GmbH}$ ). Os aminoácidos foram quantificados utilizando padrões de aminoácidos $10 \mathrm{pmol} / \mu \mathrm{l}$.

\subsubsection{Análise por espectrometria de massas}

A análise por Liquid Chromatography - Mass Spectrometry/Mass Spectrometry (LC-MS/MS) foi realizada utilizando o sistema UltiMate 3000 RSLC nano LC (Dionex, Idstein, Germany) acoplado ao sistema Q Exactive (Thermo Fisher Scientific, Bremen, Alemanha). O carregamento da amostra na coluna $(100 \mu \mathrm{m} \times 2 \mathrm{~cm}$, tamanho de partícula $5 \mu \mathrm{m}$, tamanho do poro $100 \AA$, C18, Thermo Scientific) foi realizada automaticamente a uma vazão de 30 $\mu \mathrm{l} / \mathrm{min}$ a $60^{\circ} \mathrm{C}$ com TFA a $0,1 \%$ ). A ligação entre o sistema de HPLC e $Q$ Exactive é realizada online, e a ionização foi realizada por electrospray. A tensão de vaporização dos íons foi ajustada para 1,600 V (+) e a temperatura do capilar para $250^{\circ} \mathrm{C}$. O alcance de leitura foi definido como $350-1400 \mathrm{~m} / \mathrm{z}$ para o modo de leitura completa, e para as verificações do tipo SIM (Selectedlon Monitoring), uma resolução de 70.000 (a 200 m/z) foi criado.

Os fragmentos para análise de MS/MS foram gerados utilizando a dissociação induzida por colisão de alta energia (High-Energy Collision-Induced Dissociation - HCD). Para a dissociação dos íons, uma energia de colisão normalizada (Normalized Collision Energy - NCE) foi feita a $27 \%$, a seguinte análise dos fragmentos foi realizada em um analisador do tipo Orbitrap. 
Os dados primários resultantes da análise LC-MS/MS foram interpretados usando Proteome Discoverer (versão 1.4.0.288), com base no banco de dados UniProt (UniProt/SwissProt-Release 2013_05 of 01.05.2013; 541,561 (with decoys) (http://www.uniprot.org)) como referências de sequências de proteínas. A taxonomia foi definida como homo sapiens. O banco de dados utilizado foi randomizado a fim de identificar o nível de falso positivo, ou, o conhecido, False Discovery Rate (FDR) foi ajustado para $0,01 \%$. Além disso, as seguintes modificações dinâmicas foram assumidas: oxidação e carbamidometil. Os arquivos em formato MGF resultantes foram analisados com software Ingenuity ${ }^{\circledR}$ Pathway Analysis (IPA; versão 18488943) (http://www.ingenuity.com/products/ipa), utilizando a ferramenta de análise de núcleo.

\subsection{Isolamento das amostras através da técnica de microdissecção a laser}

Neste tópico, o tronco encefálico de um indivíduo foi selecionado. A região toda da substância negra pars compacta do hemitronco esquerdo foi isolada. No hemitronco direito, apenas neurônios da substância negra pars compacta foram isolados (vide figura 13 para exemplo do isolamento da região (A) e apenas de neurônios (B)). 

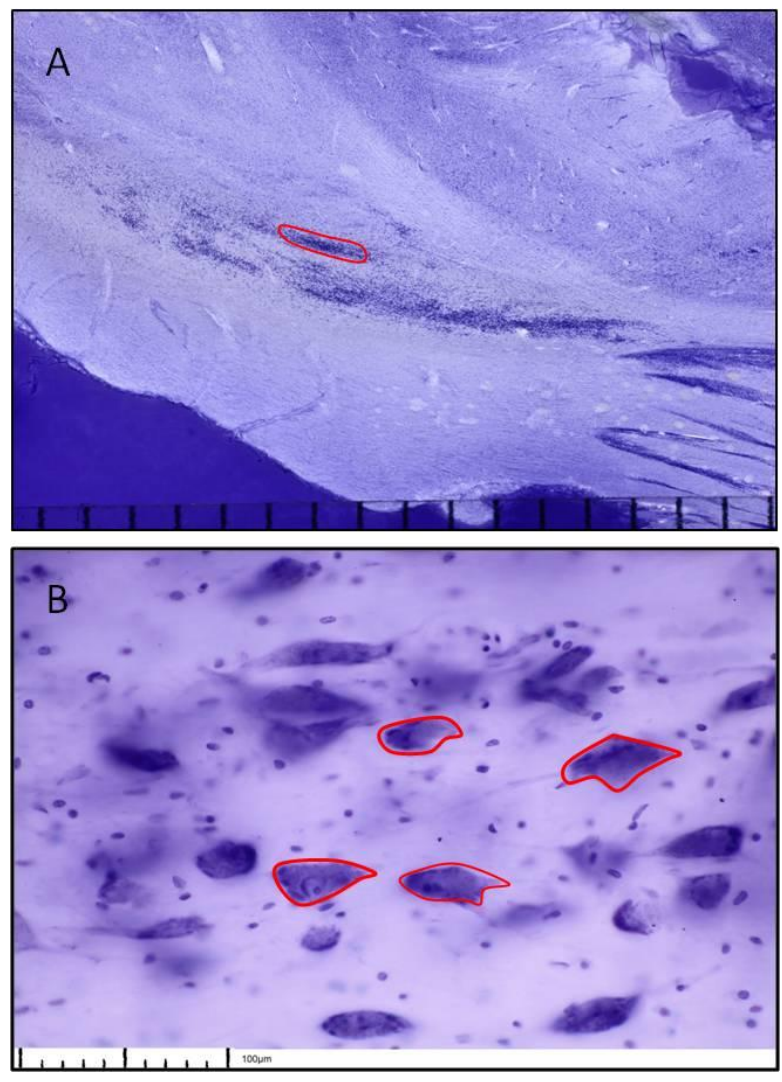

Figura 13. Seleção da área para realizar a MCL.

$\mathrm{O}$ isolamento de ambos foi realizado seguindo os melhores resultados do protocolo de MCL, descrito nos itens: 3.4 .2 e 3.4.3. As análises proteômicas foram realizadas também de acordo com o protocolo mais adequado, apresentado na sessão: 3.5 . 
4. RESULTADOS 


\subsection{Protocolo para a realização da técnica de MCL}

\subsubsection{Definição do plano ideal para a MCL da substância negra}

Fundamentado na neuroanatomia da região analisada, o plano sagital foi o escolhido, por propiciar o reconhecimento mais fácil da camada da pars compacta e dos neurônios. Além disso, as fibras neuronais se encontram dispostas de maneira que contribuem com o reconhecimento dos neurônios (Figura 14).
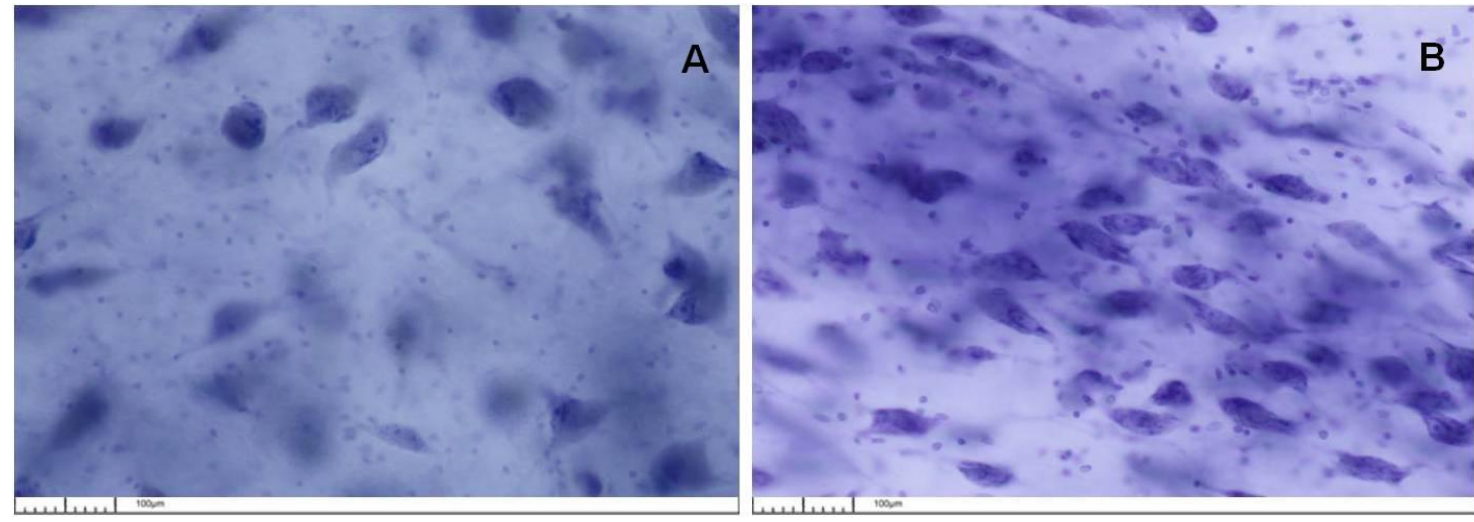

Figura 14. Diferença neuroanatômica dos neurônios da substância negra visualizados através de $(A)$ plano horizontal $(B)$ plano sagital. Magnitude: 20x. Cedido por Helmut Heinsen.

\subsubsection{Método de congelamento para MCL}

A análise qualitativa das lâminas demostrou que há maior preservação, integridade e melhor qualidade do material nas amostras congelados primeiramente em nitrogênio líquido e em seguida armazenadas em freezer $80^{\circ} \mathrm{C}$. As fotos das lâminas analisadas estão apresentadas na Figura 15. 

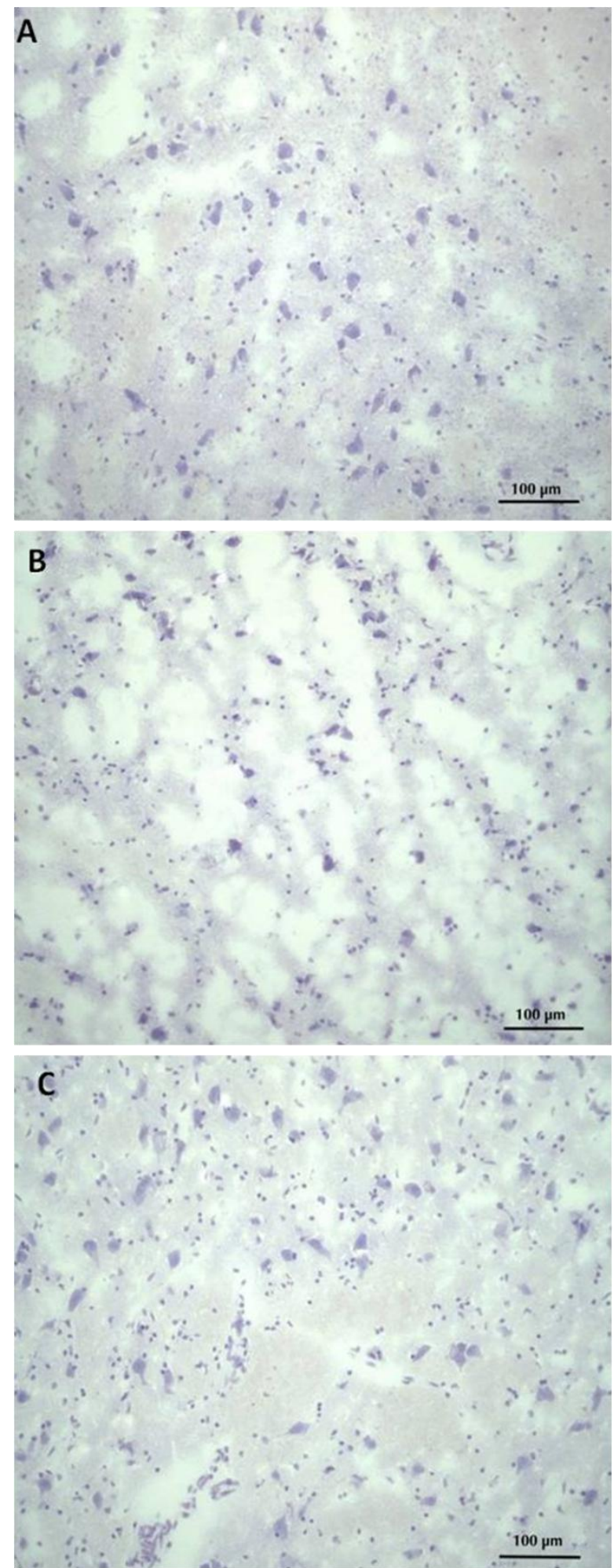

Figura 15. Comparação da otimização do procedimento de congelamento para MCL. Na figura A o tecido foi congelado em freezer $-20^{\circ} \mathrm{C}$ e armazenado a $80^{\circ} \mathrm{C}$. Figura $\mathrm{B}$ o tecido foi congelado diretamente a $-80^{\circ} \mathrm{C}$. Na figura $\mathrm{C}$ o tecido foi congelado por imersão em nitrogênio líquido e armazenado em $-80^{\circ} \mathrm{C}$. Arquivo pessoal 
4.1.3 Espessura do corte para MCL

Ensaios de quatro espessuras diferentes $(5 \mu \mathrm{m}, 10 \mu \mathrm{m}, 20 \mu \mathrm{m}$ e $30 \mu \mathrm{m})$ revelaram que a precisão de corte a laser diminui com o aumento da espessura. Nós utilizamos 5-10 $\mu \mathrm{m}$ para isolar apenas neurônios e 10-20 $\mu \mathrm{m}$ para dissecar regiões da substância negra. Essas definições possibilitaram melhor delimitação e exigiram apenas um único tiro de laser para área microdissecada ser ejetada (Figura 16).
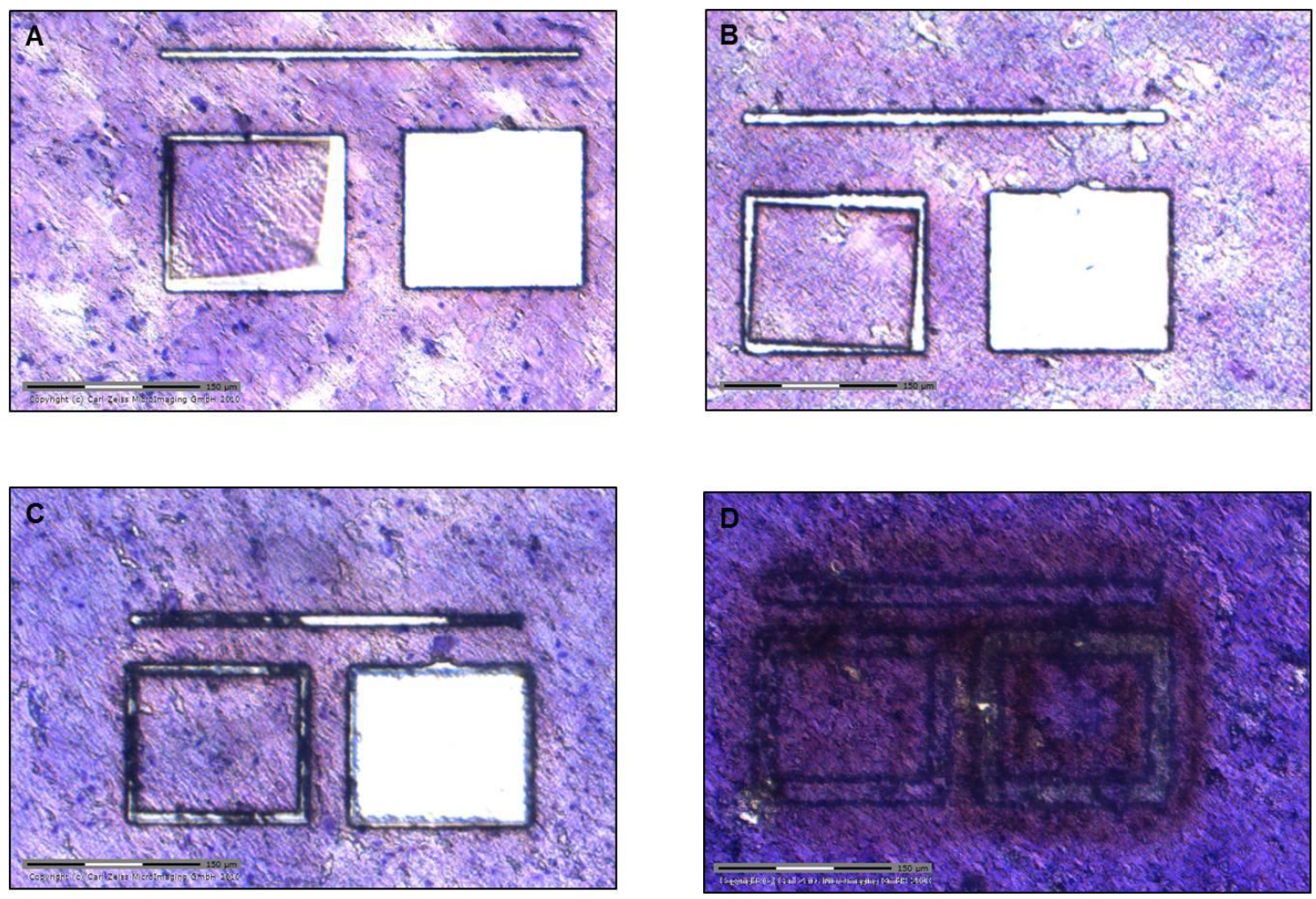

Figura 16. Otimização da espessura ideal para o isolamento de neurônios da substância negra. Quatro espessuras diferentes foram testadas: $5 \mu \mathrm{m}(\mathrm{A})$, de $10 \mu \mathrm{m}(\mathrm{B}), 20 \mu \mathrm{m}(\mathrm{C})$ e $30 \mu \mathrm{m}(\mathrm{D})$. Arquivo pessoal. 
A utilização do violeta de cresila como corante minimizou a coloração de fundo, proporcionou que as células fossem facilmente reconhecidas e não interferiu nas análises proteômicas.

\subsection{Otimização do protocolo de preparação das amostras para espectrometria de massas}

4.2.1 Otimização da solução de coleta das amostras microdissecadas

As células para análises proteômicas devem ser isoladas em solução otimizada. Foram testadas duas soluções diferentes (água e $50 \%$ de acetonitrila) utilizando toda região da substância negra pars compacta. A análise por espectrometria de massa revelou quantidades iguais de proteínas identificadas, após isolamento em água ou acetonitrila. Por não observamos diferenças relevantes, a água foi à solução de coleta selecionada para realizar a MCL pela facilidade de utilização.

\subsubsection{Ajustes na MCL para análises por espectrometria de massas}

Avaliamos a área que deve ser isolada para uma adequada análise por espectrometria de massas. A área necessária depende diretamente do tipo de tecido e da espessura do mesmo. Pelo menos, 100ng de proteínas devem ser coletados para uma análise eficaz por espectrometria de massas. Assim, verificamos que, 25.000 .000 de $\mu \mathrm{m}^{2}$ de área foi necessário para analisar toda a região da substância negra em fatias cortadas a $20 \mu \mathrm{m}$ de espessura. Em relação ao isolamento de apenas neurônios, um total de aproximadamente 2.500 neurônios $\left(1.500 .000 \mu^{2}\right.$ ) foram isolados cortados a $10 \mu \mathrm{m}$ de espessura. 
4.2.3 Preparação das amostras e análise por espectrometria de massas

Neste trabalho, um protocolo padrão de digestão com tripsina foi realizado para estudar a substância negra. Foram analisados os números de proteínas identificadas, as suas localizações e os tipos. Utilizando este protocolo foi possível identificar 1.144 proteínas da substância negra.

Analisando a região toda da substância negra pars compacta a maior parte das proteínas estavam localizadas no citoplasma (66\%). As proteínas que foram associadas com a membrana plasmática somaram $15 \%$ do total dos grupos de proteínas identificadas. Também foi avaliada a distribuição dos tipos de proteínas. No total, $13 \%$ das proteínas foram identificadas como transportadoras (11\%) e como proteínas de canal iônico (2\%).

Em relação às análises de apenas neurônios encontramos padrão semelhante de distribuição. Do total de 303 proteínas identificadas, 71\% estavam localizadas no citoplasma. Com relação às proteínas associadas com a membrana plasmática, o resultado foi de $14 \%$. No total, $12 \%$ foram associadas a proteínas transportadoras e $1 \%$ a proteínas de canal, compondo $13 \%$ das proteínas identificadas. Estes resultados indicam que o protocolo de digestão com tripsina pode ser utilizado para investigações proteômicas do encéfalo humano. Na Figura 17, os resultados desta análise estão resumidos, de modo proporcionar uma visão do proteoma da substância negra. 


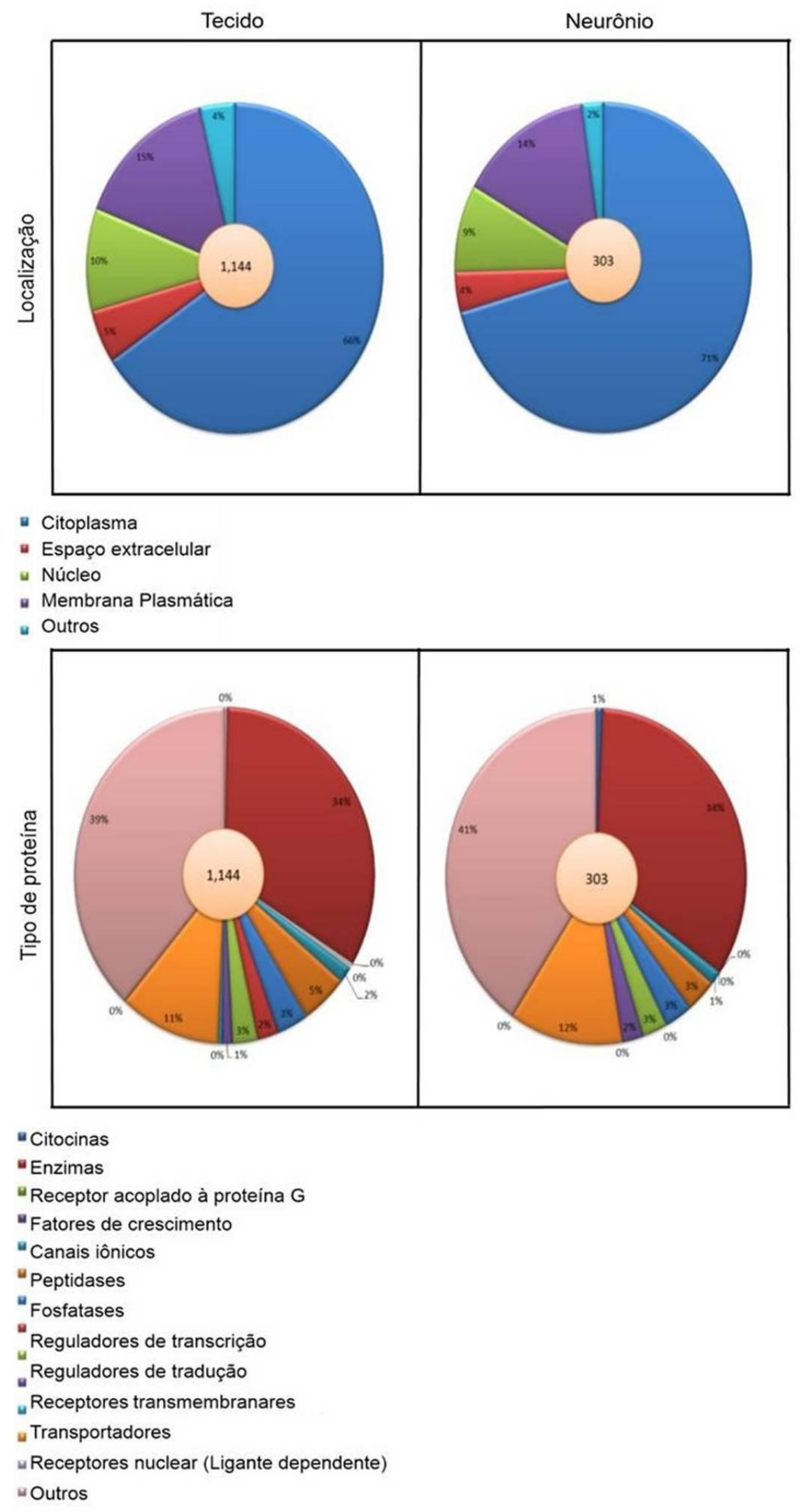

Figura 17. Análise por espectrometria de massas da substância negra. Um total de 1.144 proteínas foram identificadas em todo o tecido da substância negra (parte esquerda da figura), na parte superior da figura as análises de acordo com a sua localização e tipo (parte inferior da figura). Arquivo pessoal. 
5. DISCUSSÃO 
Neste trabalho, descrevemos e validamos uma abordagem para estudar populações de neurônios da substância negra utilizando a técnica de microdissecção e captura a laser. Esta abordagem foi eficaz para aplicação proteômica e embora nosso enfoque tenha compreendido apenas os neurônios com neuromelanina da substância negra de humanos, este protocolo pode ser adequado para outros tipos de células em seres humanos, bem como em modelos animais.

A combinação de técnicas que permitem a dissecção precisa de células individuais de um determinado tecido e posterior análise molecular é de grande interesse na área cientifica, pois permite uma compreensão mais profunda sobre os sistemas biológicos, bem como os mecanismos que desencadeiam doenças. Em nosso meio sua contribuição é promissora, pois pode colaborar de forma relevante com entendimento do tecido cerebral, das doenças relacionadas ao envelhecimento, sobretudo as doenças neurodegenerativas, incluindo a doença de Parkinson.

Mudanças nas populações neuronais específicas são comumente mascarados em análises globais, onde os encéfalos inteiros ou partes dele ao invés de grupos de células específicas são homogeneizados para posteriores análises. O mesmo ocorre em outros órgãos. Em 2015, Datta e colaboradores exemplificaram que miócitos e fibroblastos possuem respostas diferentes diante ao infarto do miocárdio, portanto avaliações coletivas destes tipos celulares podem não colaborar com a compreensão da doença.

$\mathrm{Na}$ pesquisa biomédica, muitas estratégias surgiram e têm sido aplicadas, visando entender o que é fisiológico, patológico e o limite entre ambos. Entre estas técnicas, se destaca a microdissecção e captura a laser, desenvolvida em 1996 e que permite o isolamento de células específicas dentro de um tecido (Emmert-Buck et al., 1996). Em combinação com métodos que permitem a análise de pequenos volumes de amostras, novos insights sobre cascatas patológicas, opções de terapia, neuroproteção e biomarcadores pré-clínicos podem se tornar possíveis. No entanto, a combinação destas técnicas recentes apresentam limitações, dependendo dos objetivos do estudo. 
No presente estudo, ao focar em neurônios da substância negra de idosos cognitivamente e neuropatologicamente normais, nosso objetivo foi superar alguns obstáculos técnicos e adequar o protocolo de modo que ele possa ser usado em outras abordagens.

\subsection{Plano anatômico ideal para a MCL da substância negra}

Em 1865, o psiquiatra e neuroanatomista francês Jules-Bernard Luys, contribuiu significativamente com o entendimento da anatomia do cérebro humano. Em seu livro, Luys desvendou a organização celular de vários componentes dos núcleos da base e apresentou as primeiras imagens dos neurônios da substância negra. Ele também observou que os neurônios da substância negra eram intensamente corados porque continham pigmentos escuros (Luys, $1865^{1}$ apud Parent e Parent, 2010). Após o trabalho pioneiro de Luys, outros pesquisadores forneceram descrições detalhadas sobre a substância negra humana. Em 1910, Torata Sano subdividiu a substância negra em pars compacta, no qual abrigava uma população de neurônios densamente pigmentados, e pars reticulata, que continha um número menor de neurônios pigmentados (Sano, $1910^{2}$ apud Parent e Parent, 2010).

Desde então, diversos autores tem caracterizado a substância negra, as definições e terminologias que incluem divisões e sub-regiões variam de autor para autor (Braak e Braak, 1986; Fearnley e Lees, 1991; Gibb e Lees, 1991; van Domburg e ten Donkelaar, 1991; McRitchie et al., 1995; McRitchie et al., 1996; Damier et al., 1999a;).

No entanto, até o momento, na literatura não há um consenso sobre a organização interna da substância negra humana, há falta de dados normativos

\footnotetext{
${ }^{1}$ Luys JB. Recherches sur le système nerveux cérébro-spinal text. Baillière. 1865.

${ }^{2}$ Sano D. Beitrag zur vergleichenden Anatomie der Substantia nigra, des Corpus Luysii und der Zona incerta.(Fortsetzung). European Neurology.1910;27(3);274-283.
} 
validados especialmente para os indivíduos mais idosos. Por esta razão, nós utilizamos o método de inclusão em celoidina (Cabello et al., 2002) para analisar a morfologia e determinar o melhor plano para a coleta dos neurônios.

A técnica histológica foi escolhida por ainda ser considerada o padrãoouro para a descrição precisa da neuroanatomia e para a caracterização do tecido cerebral (Dauguet et al., 2007).

\subsection{Processo de congelamento para MCL}

A microdissecção e captura a laser revolucionou a análise molecular de tecidos complexos, porque combina a precisão topográfica da microscopia com o poder da genômica, proteômica, entre outros. No entanto, o sucesso das análises moleculares ainda depende do desenho experimental e exige a compreensão de cada etapa técnica envolvida na preparação das amostras.

Ao realizar buscas de dados literários, é notório que tecidos embebidos em parafina e tecidos congelados são os métodos de preparo mais comumente utilizados para realizar a MCL. Na neurociência, ambos são recursos inestimáveis para estudos moleculares das doenças que afetam o sistema nervoso central, especialmente os distúrbios neurodegenerativos (Wang et al., 2013).

Em nosso trabalho, optamos por realizar análises proteômicas utilizando tecido fresco congelado, fundamentados pelo fato de que, o tecido fresco preserva a integridade do RNA e proteínas (Goldsworthy et al., 1999) e amostras de tecidos congelados são considerados padrão-ouro para análises moleculares (Perlmutter et al., 2004) e imperioso para análises proteômicas.

Wang e colaboradores, em 2013, identificaram que o método ideal para extração de DNA do tecido encefálico humano é obtido a partir do tecido congelado. Eles descreveram que embora o DNA possa ser extraído de ambas amostras, eles alcançaram $100 \%$ na taxa de sucesso de extração de DNA do tecido congelado, comparado a $76 \%$ em tecido parafinizado. 
Através da técnica de cromatografia líquida, Scicchitano e colegas (2009) compararam amostras embebidas em parafina e amostras congeladas e verificaram que o rendimento de proteínas foi menor nas amostras fixadas em formalina. Eles ainda ressaltaram que são necessários métodos fiáveis para a obtenção de perfis proteômicos em amostras fixadas e embebidas em parafina, já que as análises proteômicas de suas amostras foram confundidas, induzidas pelo processo conhecido como "cross-linking" ou ligações cruzadas.

Além disso, a parafina não tem se mostrado compatível com LC-MS/MS porque requer um passo de desparafinização, resultando na perda de proteínas (Hood et al., 2005; Hood et al., 2006).

Ainda buscando o método ideal para preservar a integridade e a morfologia do tecido em estudo, e para minimizar possíveis erros em nossas análises, testamos diferentes protocolos de congelamento. De acordo com os resultados obtidos neste trabalho, podemos afirmar que o melhor método de congelamento é a imersão do tecido em nitrogênio líquido e o imediato armazenamento em freezer a $-80^{\circ} \mathrm{C}$. A congelação lenta promove a formação de cristais de gelo no interior do tecido, que se expande e promove 0 rompimento das células e tecidos. Destacamos a importância de congelar o tecido rapidamente evitando assim a cristalização da água. A utilização de nitrogênio líquido permite que a água se transforme em estado vítreo, que não se expande.

Em relação à conservação do material, Ferrer et al. (2007) e Kretzschmar (2008) relataram que amostras armazenadas em freezer a $-80^{\circ} \mathrm{C}$ permanecem adequados para estudos moleculares por anos.

\subsection{Espessura do corte para MCL}

A MCL é um processo que depende de vários parâmetros, cada um dos quais deve ser otimizado para cada tipo de amostra. As configurações são influenciados pelo tipo de tecido a ser isolado. Portanto, é essencial investigar essas configurações para cada coleta. 
Para avaliar a capacidade de precisão do corte a laser, foram analisados neste trabalho diferentes espessuras de corte. Muitos autores (Kerk, 2003; Rodriguez et al., 2008) defendem que esta determinação é um passo crucial para estudos utilizando MCL. Em particular, a espessura de corte é essencial para o bom processamento da microdissecção a laser.

Nossos achados revelaram que a precisão do corte a laser diminui com o aumento da espessura e esses resultados vão de acordo com os de Curran et al., 2000; Wang et al., 2009; De Carlo et al., 2011. Estes autores descreveram que são necessárias energias mais elevadas para secções de 20 $\mu \mathrm{m}$ de espessura quando comparados a secções de $10 \mu \mathrm{m}$. Além disso, em cortes mais espessos são necessárias duas ou três emissões de laser para cortar e catapultar o tecido.

Para Wang et al. (2009) a precisão do corte de $5 \mu \mathrm{m}$ e $10 \mu \mathrm{m}$ de espessura possibilitou que até mesmo células muito pequenas fossem isoladas, sem danificar o tecido adjacente.

Embora nosso achado de realizar os cortes a $10 \mu \mathrm{m}$ concorde com outros trabalhos (Györkey et al., 1967; Dembinsky et al., 2007; Reidel et al., 2011) muitos estudos (Mikulowska-Mennis et al., 2002; Hommel et al., 2003; Park e Cunningham, 2007; Stephenson et al., 2007; St Martin et al., 2007; Gründemann et al., 2008) são realizados utilizando diferentes espessuras, indicando que, para diferentes objetivos e tecidos, diferentes espessuras devem ser testadas.

\subsection{Coloração para MCL}

Desde a invenção original da MCL na década de 1990, esta tecnologia continua a avançar e evoluiu consideravelmente em vários aspectos. (Tangrea et al., 2011; Jensen, 2013). No entanto, a resolução óptica ainda é limitada.

Se tem demonstrado na literatura, um grande número de procedimentos de coloração para a MCL, entretanto, o uso lamínulas é incompatível (Fend et al., 2000), pois impossibilita a microdissecção e captura das amostras. A 
ausência de lamínulas induz uma cor mais escura do tecido e produz uma imagem pouco nítida da amostra. Para obter um melhor background, ou seja, um fundo que não interfira na identificação das células, a amostra pode ser incubada com uma concentração mais elevada de solução de coloração, no entanto, este procedimento pode afetar negativamente a análise proteômica (Gutstein e Morris 2007).

A coloração é um método muito útil para reconhecer detalhes histológicos, distinguir diferentes padrões de tecidos/células e tem importante papel nas experiências com a técnica de MCL (Fend et al., 2000; Wang et al., 2006). No entanto, a especificidade do processo de coloração e o seu efeito sobre a amostra, devem ser considerados (Standaert, 2005). A literatura contém inúmeros diferentes protocolos de coloração adequados para a técnica de MCL. Colorações comuns incluem: Hematoxilina e Eosina (HE) (De Souza et al., 2004; Dos Santos et al., 2007.); azul de toluidina (Lawrie et al., 2001; Kirana et al., 2009; Sridharan e Shankar 2012; Kulkarni et al., 2013) e violeta de cresila (Aaltonen et al., 2011; Boone et al., 2013). A técnica de imunohistoquímica também é utilizada para realizar a MCL (Fend et al., 1999) e permite distinguir tipos de células individuais, como neurônios (Pietersen et al., 2009).

A escolha do procedimento de coloração depende não só da amostra, mas também, dos procedimentos adicionais de processamento da amostra e dos objetivos do estudo. Técnicas de coloração têm um impacto significativo sobre as propriedades do tecido e pode influenciar amplamente a análise do proteoma. Portanto, em nosso estudo era essencial que a técnica de coloração não interfirisse com as proteínas, que fosse compatível com MCL e com análise por espectrometria de massas. Por exemplo, investigações anteriores demonstraram que a coloração de HE não é compatível com a análise de proteômica (Ahram et al., 2003; Gutstein e Morris, 2007). Vários outros grupos confirmaram a influência da coloração HE em análises proteômicas (Craven e Banks, 2001; Craven et al., 2002; Sitek et al., 2005). No entanto, para Burgemeister e colegas (2003) essa coloração não mostrou nenhum efeito sobre estudos de amostras de RNA e DNA. O azul de toluidina é frequentemente utilizado para as análises de DNA e RNA utilizando a MCL 
para coletar as amostras (Kulkarni et al., 2013) e também pode ser utilizado para análises proteômicas (Lawrie et al., 2001). Em contraste, um grupo de pesquisadores investigaram amostras de rim corados com azul de toluidina e notaram efeitos prejudiciais, identificados na recuperação de proteína na análise de gel 2D (Craven et al., 2002).

Alguns grupos de pesquisa tem adaptado técnicas de coloração imunohistoquímica para MCL (Fend e Raffeld, 2000; Murakami et al., 2000; He et al., 2013). Este processo auxilia os investigadores a determinar as moléculas de interesse em tecidos heterogêneos (Murakami et al., 2000;. Buckanovich et al., 2006), porém, uma das limitações da imuno-histoquímica para a MCL é que a amostra não se torna adequada para estudos da dinâmica da proteína devido a ligação do anticorpo a proteína de interesse (Jensen, 2013).

A técnica utilizando violeta de cresila é especialmente comum para a coloração de neurônios. Trata-se de uma solução catiônica (Mouledous et al., 2003) e se liga aos componentes ácidos do núcleo e do citoplasma neuronal, especialmente ribossomos, que estão presentes em grandes números nos neurônios (Eltoum et al., 2002; Burnet et al., 2004). Clément-Ziza e colaboradores adaptaram o procedimento de coloração utilizando violeta de cresila para análise de RNA, substituindo todos os solventes com etanol, o que impede a degradação da amostra (Clément-Ziza et al., 2008). Para Ginsberg e Che (2004) em comparação com outras colorações comuns, o violeta de cresila proporciona um bom contraste no tecido.

Em nosso estudo, não observamos qualquer interferência da coloração com violeta de cresila na análise por espectrometria de massas, inclusive esta observação tem sido apoiada na literatura e muito utilizada em abordagens proteômicas (Boggio et al., 2011; Andersson et al., 2008; Caudle et al., 2008; Seeley e Caprioli, 2011; Reyze e Caprioli, 2005).

\subsection{Microdissecção e captura a laser}


Nos últimos anos, o campo da patologia molecular tem evoluido consideravelmente com a integração de sistemas de microdissecção a laser e uma variedade de ensaios biológicos (Emmert-Buck et al., 1996; Bonner et al., 1997; Vrana et al., 2009) A MCL é igualmente uma técnica promissora para estudos do proteoma do encéfalo (Uhlén et al., 2005; Begcevic et al., 2013).

No entanto, para cada tipo de tecido, parâmetros específicos são necessários, porque o desempenho da MCL depende de várias condições, cada um dos quais, devem ser aprimorados. As definições são influenciadas pelo tipo de tecido, células ou regiões que serão isoladas, pela espessura do corte, pela energia do feixe do laser aplicada e pelo tampão utilizado na amostra. Além disso, a MCL pode ser interferida pela temperatura e umidade (Ordway et al., 2009). Essas condições afetam as configurações de energia necessárias para a microdissecção e este processo deve ter ajuste diário. Por isso, é especialmente importante otimizar os parâmetros listados anteriormente. Cortes mais finos são aconselháveis para a microdissecção de células individuais ou de pequenas áreas, a fim de garantir que nenhum tecido adjacente seja coletado (Wang et al., 2009).

Para coletar as amostras, tampas adesivas podem ser utilizadas (Spee et al., 2010), como uma alternativa de coletar em soluções tampão (Cermelli et al., 2003). Tampas adesivas contém material adesivo para recolher as amostras e dispensam o uso de tampão. Nós não usamos estas tampas adesivas para evitar a possível contaminação e limitar a exposição de substâncias que podem perturbar a análise por espectrometria de massas.

Embora a MCL tenha inúmeras vantagens, as suas desvantagens devem ser consideradas. O equipamento, bem como seus consumíveis são caros, o aparelho pode custar mais de um milhão de dólares (Chung e Shen, 2015). Existe um risco admissível de que a qualidade dos tecidos microdissecados podem não satisfazer a qualidade padrão para análises posteriores devido à exposição a agentes fixadores, reagentes de coloração ou até a desidratação dos tecidos causada pela ausência de lamínulas (Chung e Shen, 2015).

Além desses fatores, há necessidade de uma quantidade relativamente grande de biomoléculas para algumas plataformas de análises (Jensen, 2013). 
Altelaar e Heck (2012), em seu trabalho, mostraram que independente da amostra, pelo menos, $100 \mathrm{ng}$ de tecido devem estar presentes para garantir uma adequada análise por espectrometria de massas.

Acredita-se que o desenvolvimento de sistemas e a integração de softwares sofisticados de análises de imagens poderão permitir a microdissecção de células automaticamente, desde que a região de interesse seja previamente definida. Jensen (2013), defende que esse avanço deverá aumentar consideravelmente a precisão e a velocidade de se obter as células, bem como, auxiliar na coleta de um volume significativo de amostras e consequentemente análises moleculares em maior escala.

\subsection{Preparação das amostras para espectrometria de massas}

Pelo menos $100 \mathrm{ng}$ de tecido devem ser coletados para garantir uma análise por espectrometria de massa de alto desempenho (Altelaar e Heck, 2012). Em nosso estudo atingimos uma adequada análise por espectrometria de massas utilizando $500.000 .000 \mu \mathrm{m}^{3}$ de tecido da substância negra e 15.000.000 $\mu^{3}$ de neurônios da substância negra. No entanto, se a área necessária depende do tipo de tecido e de células, ela deve ser examinada, para cada tipo de tecido individualmente. Por exemplo, o número de proteínas identificadas apenas em neurônios isolados poderá ser reforçada se mais neurônios forem isolados.

Além disso, para alcançar análises proteômicas comparativas, é importante estabelecer um protocolo específico e reproduzível de preparação da amostra e a etapa de digestão é crucial. Digestão com tripsina é comumente usada em pesquisa proteômica (López-Ferrer et al., 2008; Gupta et al., 2010; Hao et al., 2011; Sun et al., 2014), esta técnica produziu bons resultados nas amostras isoladas a partir da MCL. No entanto, a utilização de tripsina deve ser considerada, principalmente trabalhos que estudam o encéfalo, já que, proteínas associadas à membrana, são de grande interesse. 
As proteínas de membrana, que estão presentes na membrana plasmática e em compartimentos subcelulares, impactam diretamente nos processos de sinalização, essas proteínas garantem a homeostase celular e função cerebral. Por isso, são altamente relevantes na pesquisa proteômica, especialmente as proteínas transportadoras, receptoras e proteínas de canais iônicos.

A importância de tais proteínas é especialmente perceptível em doenças neurodegenerativas. Por exemplo, na doença de Parkinson, a proteína $\alpha-$ sinucleína é bem conhecida por interagir com a membrana plasmática. Alterações nesta proteína parecem afetar a liberação de neurotransmissores (Jenco et al., 1998; Lotharius e Brundin, 2002; Sidhu et al., 2004).

As proteínas localizadas na membrana são frequentemente de caráter hidrofóbico, o que torna a realização de análises proteômicas um desafio (Helling et al., 2012), ou seja, para analisar as proteínas de membrana, os protocolos estabelecidos para as proteínas citosólicas, geralmente solúveis devem ser modificados. Existem várias técnicas de preparação de amostra para o enriquecimento de proteínas de membrana, como por exemplo, o uso do brometo de cianogênio. Helling e colaboradores utilizaram este tipo de preparação da amostra para a análise fosfoproteômica do complexo da proteína de membrana citocromo c oxidase e encontraram uma melhora na análise por espectrometria de massas (Helling et al. 2012). $\mathrm{O}$ uso de brometo de cianogênio pode identificar seis novos locais de fosforilação que não foram encontrados quando as amostras foram digeridas com tripsina. As proteínas da membrana são mais hidrofóbicas do que as proteínas citosólicas, indicando que a protease tripsina convencionalmente utilizada deve ser combinada com digestão com brometo de cianogênio ou métodos semelhantes (Lee et al., 2011).

Quimotripsina é outra protease utilizada. Fisher e colaboradores em 2006 testaram diferentes protocolos de digestão para investigar o proteoma de membrana de Corynebacterium glutamicum. Uma mistura de digestão contendo tripsina e quimotripsina aumentou a identificação de proteínas que continham grandes domínios hidrófobos. Além disso, a pré-digestão da amostra com tripsina diminuiu a quantidade de proteínas solúveis que 
poderiam mascarar algumas proteínas de membrana (Fischer et al., 2006). No entanto, os solventes podem também ter impacto na digestão e a otimização pode ser um fator chave para melhorar o protocolo (Russell et al., 2001). 
6. CONCLUSÕES 
I. O protocolo desenvolvido permitiu congelar, seccionar e corar o tecido de forma eficiente para microdissecção a laser;

II. A microdissecção a laser e subsequente análise proteômica foram eficazes. A caracterização preliminar do conteúdo proteico da substância negra evidenciou diferenças significativas em relação à quantidade de proteínas quando comparamos $\mathrm{o}$ isolamento realizado em toda a substância negra pars compacta e 0 isolamento apenas dos neurônios. Porém, não encontramos diferenças significativas no padrão de distribuição destas proteínas. 
Este projeto é possível graças à interação do Grupo de Estudos em Envelhecimento Cerebral da Faculdade de Medicina da Universidade de São Paulo com o Centro de Proteômica Médica da Universidade de Bochum, Alemanha.

Para o estabelecimento dos protocolos, bem como, desenvolvimento deste trabalho, durante os meses de maio de 2013 e maio de 2014 tive a oportunidade de conhecer e trabalhar no Centro de Proteômica Médica da Universidade de Bochum, coordenado pela Dra. Katrin Marcus. Neste período, além de desenvolver o protocolo, estive em contato com as técnicas preliminares necessárias para realização das análises proteômicas e aprendi a interpretar os resultados obtidos na espectrometria de massas.

Ademais, a aluna Simone Kutschki da Universidade de Bochum esteve nos meses de outubro e novembro de 2013 na FMUSP, conviveu com a rotina do Grupo de Estudos em Envelhecimento Cerebral e pudemos dar continuidade a otimização dos protocolos.

Além disso, durante o período que estive na Alemanha (Maio de 2013) junto à minha co-orientadora Dra. Renata Elaine Paraizo Leite pude conhecer o Laboratório de Pesquisa em Morfologia Cerebral da Clínica de Psiquiatria da Universidade de Würzburg, coordenado pelo Prof. Helmut Heinsen. Esta visita contribuiu com o aprendizado sobre a morfologia da substância negra e a determinação do plano anatômico utilizado neste estudo.

Acredito que as experiências adquiridas durante estes intercâmbios tiveram grande importância científico-acadêmica para com a minha formação e somaram de maneira grandiosa com a elaboração deste trabalho.

É importante ressaltar que, no momento em que desenhamos este estudo, além da validação proteômica subsequente à microdissecção a laser, nosso objetivo era também caracterizar o conteúdo proteico dos neurônios contendo neuromelanina na substância negra de 5 indivíduos do gênero masculino, sem alterações clínicas e neuropatológicas. No entanto, após o estabelecimento do protocolo, dois fatos relevantes atrasaram 0 desenvolvimento do trabalho: I) Cinco casos enviados à Alemanha em maio de 
2014, sofreram atraso alfandegário e sanitário, que foge ao nosso controle. Esses casos sofreram descongelação, o que nos levou a excluí-los e realizar novas coletas para preencher a casuística desejada. II) o equipamento multiusuário a ser utilizado para dissecção a laser precisou de reparos de agosto de 2014 a julho de 2015, o que impossibilitou sua utilização no período. Este aparelho está localizado nas dependências da Faculdade de Medicina da Universidade de São Paulo (FMUSP), no Laboratório de Patologia Molecular, coordenado pelo Prof. Dr. Chin Jia Lin e possui o sistema PALM Microbeam (Zeiss, LCM PALM-System, Carl Zeiss Microscopy, GmbH).

Dessa forma, optamos por publicar o protocolo desenvolvido enquanto novos casos do gênero masculino foram coletados, processados e corados para caracterização neuropatológica. Estes novos 5 casos já estão caracterizados e serão analisados em breve. O protocolo foi publicado na revista Journal of Neural Transmission, com fator de impacto 2.402.

Este projeto teve apoio financeiro do Conselho Nacional de Desenvolvimento Cientifico e Tecnológico (CNPq), sob a proposta de Acordo de Cooperação Bilateral, número do processo: 490709/2013-3 do Edital Alemanha DLR. 
8. ANEXOS 


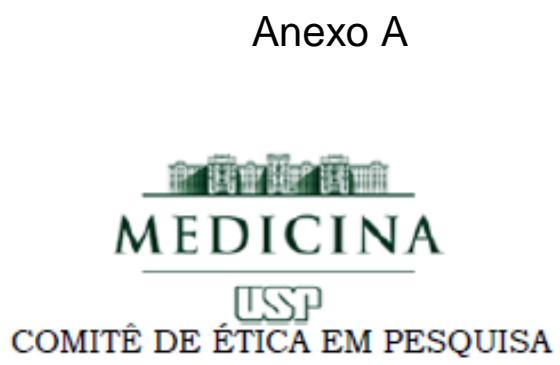

O Comitê de Ética em Pesquisa da Faculdade de Medicina da Universidade de São Paulo, em sessão de o9.o2.11 APROVOU o Protocolo de Pesquisa n ${ }^{0}$ 61/10 intitulado: "ANÁLISE PROTEÔNICA DOS GRÂNULOS DE NEUROMELANINA NO ENVELHECIMENTO NORMAL E NA DOENÇA DE PARKINSON", e seus anexos, apresentado pelo Departamento de Patologia da FMUSP" tendo como pesquisadora responsável Dra. Lea Tenenholz Grinberg e pesquisadora executante Renata Elaine Paraizo Leite

Cabe ao pesquisador elaborar e apresentar ao CEP-FMUSP, os relatórios parciais e final sobre a pesquisa .

o pesquisador deverá aguardar a aprovação da CONEP para iniciar a pesquisa.

CEP-FMUSP, o9 de fevereiro de 2011.

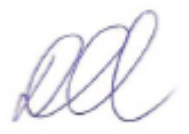

Prof. Dr. Daniel Romero Muñoz Vice-Coordenador Comitê de Ética em Pesquisa 


\section{Anexo B}

\section{A.1. A:1 \\ MEDICINA \\ Comitê de Ética em Pesquisa}

CEP-040/11

São Paulo, 27 de maio de 2011

Ima. Sra.

Dra. Lea Grinberg

Departamento de Patologia

Por determinação do Senhor Coordenador, encaminhamos para conhecimento cópia do Parecer CONEP 271/11 datado de 25.04.11 referente a APROVACÃO do projeto de pesquisa CEP $361 / 10$, Registro CONEP 16380 intitulado "Análise proteômica dos grânulos de neuromelanina no envelhecimento normal e na doença de Parkinson.", sob sua responsabilidade.

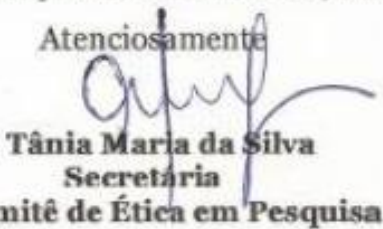




\section{Anexo C}

Data Óbito: H. Óbito: H. Necro: $\Delta \mathrm{T}$ Morte: H Início Entrev:

Nome: Idade: DN:

Sexo: N P A Natural:

Proced: Estado Civil: Escolaridade: anos (

Profissão: do lar doméstica outros

Situação: Ainda trabalhava Aposentado Dextro

$S$

D Filhos:

Informante

Parentesco:

Freq com o pcte: D S M a Outro

Escolaridade do informante: Com quem residia:

Causa do Óbito:
Causas básicas/ achados clínicos:
Como correu o óbito: em casa logradouro público no hospital/ transferência/ APH:

$\longrightarrow$

HPMA:

AP: Nega ou desconhece qualquer antecedente patológico

HAS DM DAC ICC (TF, Arritmia MP IVP/OAC IRC DLP TCE

AVCi // h prévio? Há _ a - sem seqüela com seqüela: cognitiva motora

AIDS Sífilis $\overline{\mathrm{AO} / \mathrm{OP}}$ Dist Tireóide Bronquite/ Asma DPOC

Down Depressão Esquizofrenia Mania TOC D Parkinson Neoplasia

Internação Psiquiátrica

TTOs anteriores: Clínicos:

Cirúrgicos:

Não fazia tto ou acompanhamento médico atualmente Nunca foi ao médico: recusa/ sem acesso

Sd demencial diagnosticada em vida: não sim Há a Etiologia:

História compatível com Síndrome demencial: não $\overline{\operatorname{sim}}$

Início dos sintomas: lento súbito memória comportamento outro

Curso: lento e progressivo rápido evolução em degraus curso flutuante

\section{Função anterior à morte}

Acuidades visual e auditiva preservadas \acuidade visual óculos hipoacusia prótese

Dentição preservada falhas dent/ anodontia uso de prótese dentária disfagia SNG/SNE/GTS

Sedentário Atividade física: doméstica caminhada trabalho outra Freq /sem

Andava: s/ auxílio d/ auxílio: pessoas parede/móveis equipamentos auxiliares

Acamado___ Amputações___ Lesões cutâneas (úlceras)

Independente Dependente Tomava decisões sozinho Não tomava decisões

Em que situações convivia com muitas pessoas 
FR: Obesidade (P__ A__ IMC_________ Reposição hormonal

Tabagismo: não sim anos/maço parou Etilismo: não social alcoolismo parou

Medicaçōes que usava: Não usa: não foi prescrito controle inadequado NREF NMED Medicações:

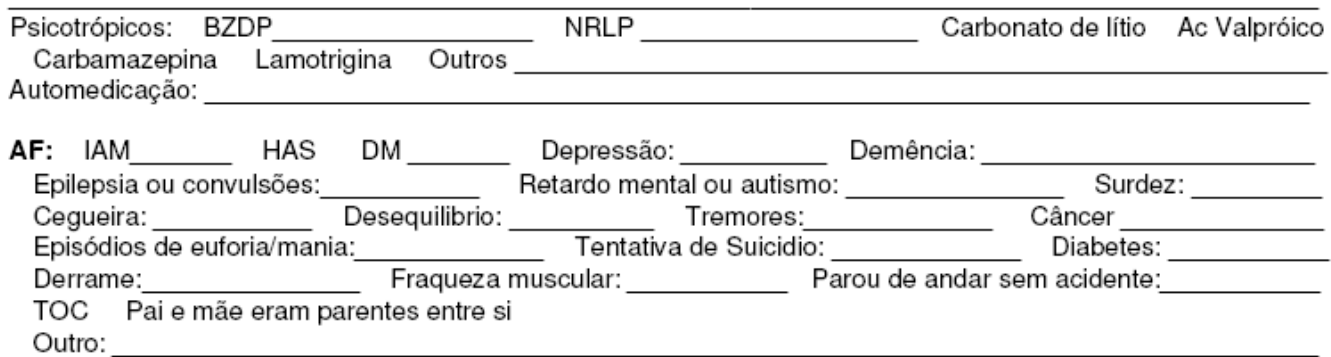

\section{Outras Informaçōes relevantes:}

\section{ESCORES DAS ESCALAS:}

IQCODE: CDR SB ABIPEME NPI: KATZ: IADL: PARK: SCID D:

\section{CONSENSO DIAGNÓSTICO}

Data: Presentes:

Diagnóstico Principal: sem comprometimento cognitivo CDR 0,5 M+ CDR 0,5 MD M+ CDR 0,5 MD MDA DV $\mathrm{DCL}$ Outras:

Outros Diagnósticos: AVE Depressão DP/ Parkinsonismo Outros:

RCV: sem RCV $\uparrow \uparrow \uparrow R C V$ 
Informant questionnaire on cognitive decline in the elderly

\section{(IQCODE - Versão retrospectiva)}

Gostaríamos que você se lembrasse de como era seu amigo ou familiar há 10 anos atrás e compare com o estado em que ele estava há 3 meses antes de sua morte.

Comparada com há 10 anos atrás, como estava a pessoa antes de sua morte:

\begin{tabular}{|c|c|c|c|c|c|}
\hline & $\begin{array}{c}\text { Muito } \\
\text { melhor } \\
\text { (1) }\end{array}$ & $\begin{array}{l}\text { Um } \\
\text { pouco } \\
\text { melhor } \\
\text { (2) }\end{array}$ & \begin{tabular}{c|} 
Não \\
muito \\
alterado \\
(3)
\end{tabular} & $\begin{array}{l}\text { Um } \\
\text { pouco } \\
\text { pior } \\
(4)\end{array}$ & $\begin{array}{l}\text { Muito } \\
\text { pior } \\
\text { (5) }\end{array}$ \\
\hline \multicolumn{6}{|l|}{ 1. Reconhecer a face das pessoas amigas e da família } \\
\hline \multicolumn{6}{|l|}{ 2. Lembrar do nome de parentes e amigos } \\
\hline \multicolumn{6}{|l|}{$\begin{array}{l}\text { 3. Lembrar de coisas sobre a família e amigos (aniversários, } \\
\text { ocupaçôes, endereços...) }\end{array}$} \\
\hline \multicolumn{6}{|l|}{ 4. Lembrar de coisas que aconteceram recentemente } \\
\hline \multicolumn{6}{|l|}{ 5. Lembrar de conversas que teve nos últimos dias } \\
\hline \multicolumn{6}{|l|}{ 6. Esquecia o que queria dizer no meio de uma conversa } \\
\hline \multicolumn{6}{|l|}{ 7. lembrar-se de seu próprio endereço e telefone } \\
\hline \multicolumn{6}{|l|}{ 8. lembrar (saber) que dia e mês era } \\
\hline \multicolumn{6}{|l|}{ 9. Lembrar onde as coisas são usualmente guardadas } \\
\hline \multicolumn{6}{|l|}{$\begin{array}{l}\text { 10. Lembrar-se de onde encontrar as coisas que foram } \\
\text { colocadas em lugares fora do comum }\end{array}$} \\
\hline \multicolumn{6}{|l|}{ 11. Adaptar-se a qualquer mudança na sua rotina diária } \\
\hline \multicolumn{6}{|l|}{ 12. Saber como funcionam os eletrodomésticos } \\
\hline \multicolumn{6}{|l|}{$\begin{array}{l}\text { 13. Aprender a usar novos eletrodomésticos/ utensílios } \\
\text { domésticos }\end{array}$} \\
\hline \multicolumn{6}{|l|}{ 14. Aprender coisas novas em geral } \\
\hline \multicolumn{6}{|l|}{$\begin{array}{l}\text { 15. Lembrar-se de coisas que aconteceram em sua vida quando } \\
\text { era jovem }\end{array}$} \\
\hline \multicolumn{6}{|l|}{ 16. Lembrar-se de coisas que aprendeu quando era jovem } \\
\hline \multicolumn{6}{|l|}{ 17. Entender o significado de palavras não comuns } \\
\hline \multicolumn{6}{|l|}{$\begin{array}{l}\text { 18. Entender o significado do que está escrito em jornais e } \\
\text { revistas }\end{array}$} \\
\hline \multicolumn{6}{|l|}{ 19. Acompanhar uma estória em um livro ou pela TV } \\
\hline \multicolumn{6}{|l|}{ 20. Escrever uma carta para um amigo ou com fins de trabalho } \\
\hline \multicolumn{6}{|l|}{ 21. Saber sobre eventos históricos importantes do passado } \\
\hline \multicolumn{6}{|l|}{ 22. Tomar decisões com problemas do dia a dia } \\
\hline \multicolumn{6}{|l|}{ 23. Manusear dinheiro para compras } \\
\hline \multicolumn{6}{|l|}{$\begin{array}{l}\text { 24. Lidar com problemas financeiros (ex: pensão, conta } \\
\text { bancária) }\end{array}$} \\
\hline \multicolumn{6}{|l|}{$\begin{array}{l}\text { 25. Lidar com outros problemas matemáticos, por exemplo: } \\
\text { saber quanto comprar de comida, saber quanto tempo se } \\
\text { passou entre as visitas dos familiares/ amigos. }\end{array}$} \\
\hline $\begin{array}{l}\text { 26. Usar sua inteligência para entender o que está acontecendo } \\
\text { e o motivo pelo qual está acontecendo. }\end{array}$ & & & & & \\
\hline
\end{tabular}

Total: 


\section{ESCORE CLÍNICO DE DEMÊNCIA - FOLHA DE REGISTRO}

Esta é uma entrevista semi-estruturada. Por favor, faça todas estas perguntas. Faça quaisquer questöes adicionais que sejam necessárias para determinar o CDR do sujeito. Por favor, tome nota das informaçōes das perguntas adicionais.

\section{QUESTÕES SOBRE MEMÓRIA PARA O INFORMANTE}

1. Ele/ela tem algum problema com sua memória ou seu pensamento (raciocínio)? SIM NÃO

1a - Se sim, é um problema constante? (em oposição a eventual, raro)

SIM NÄO

2. Ele/ela pode se lembrar de eventos recentes?

Frequentemente Às vezes Raramente

3. Ele/ela pode se lembrar de uma lista curta de itens (compras)?

Frequentemente Às vezes Raramente

4. Houve algum declínio na memória durante o último ano?

SIM NÄO

5. Sua memória está comprometida a tal ponto que teria interferido em suas atividades de vida diária de alguns anos atrás?

(ou atividades pré-aposentadoria) (opinião de outros informantes)

SIM NÃO

6. Ele/ela se esquece completamente de um evento importante (ex. viagem, festa, casamento em familia) algumas semanas depois do evento?

Frequentemente Às vezes Raramente

7. Ele/ela se esquece de detalhes pertinentes de um evento importante?

Frequentemente Às vezes Raramente

Ele/ela se esquece completamente de informaçöes importantes do passado distante (ex. data de nascimento, data de casamento, local do emprego)?

Frequentemente Às vezes Raramente

9. OBS - Questăo removida por năo ser aplicável.

\section{QUESTÕES SOBRE ORIENTAÇÃO PARA O INFORMANTE}

Com que frequência ele/ela sabe o exato:

1. Dia do Mês?

Frequentemente Às vezes Raramente Não sabe

2. Mês?

Frequentemente Às vezes Raramente Não sabe

3. Ano?

Frequentemente Às vezes Raramente Năo sabe

4. Dia da semana?

Frequentemente Às vezes Raramente Năo sabe

5. Ele/ela tem dificuldades com relacöes temporais (quando os eventos ocorreram em relaçăo uns com os outros)?

Frequentemente Às vezes Raramente Năo sabe


6. Ele/ ela pode achar seu caminho em ruas conhecidas?

Frequentemente Às vezes Raramente Năo sabe

7. Com que frequência ele/ela sabe como ir de um lugar para o outro fora de sua vizinhanca?

Frequentemente Às vezes Raramente Năo sabe

8. Com que frequência ele/ela pode encontrar seu caminho dentro de casa?

Frequentemente Às vezes Raramente Năo sabe

\section{QUESTÕES SOBRE JULGAMENTO E RESOLUÇÃO DE PROBLEMAS PARA O INFORMANTE}

1. Em geral, se você tivesse que avaliar as habilidades dele/dela para resolver problemas atualmente, você consideraria que elas são:

Tăo boas quanto sempre foram.

Regulares.
Ruins.
Boas, mas não tão boas quanto antes.

Năo há nenhuma habilidade.

2. Avalie sua habilidade em lidar com pequenas quantias de dinheiro (ex.: trocar dinheiro, dar gorjeta):
Năo há perda.
Alguma perda.
Perda grave

3. Avalie sua habilidade em lidar com transaçöes financeiras complicadas (ex.: pagar contas, controle de conta bancária):
Năo há perda.
Alguma perda.
Perda grave.

4. Ele/ela pode lidar com uma emergência doméstica (ex. vazamento nos encanamentos, pequenos incêndios):

Tåo bem quanto antes.

Pior do que antes por causa da dificuldade de pensamento (raciocínio).

Pior do que antes, por outra razăo. (qual)

5. Ele/ela pode entender situaçōes ou explicaçōes?

Frequentemente Às vezes Raramente Năo sabe

6. Ele/ela se comporta de modo apropriado* [isto é, em sua maneira usual (pré-doença)]em situaçöes sociais e em interaçăo com outras pessoas?

Frequantemente Às vezes Raramente Năo sabe

*Este item avalia comportamento, nào aparência. 


\section{QUESTÕES SOBRE ASSUNTOS COMUNITÁRIOS PARA O INFORMANTE}

\section{Ocupacional}

1. O sujeito ainda está trabalhando?

SIM NÄO NA

Se năo aplicável - vá para o item número 4

Se sim - vá para o item número 3

Se não - vá para o item número 2

2. Os problemas de memória ou de pensamento (raciocinio) contribuíram para a decisão do sujeito de se aposentar? (A questăo 4 é a próxima)

SIM NÄO NA

3. O sujeito tem dificuldade significante em seu trabalho por causa de problemas com memória ou pensamento (raciocínio)? Raramente ou nunca Às vezes Freqüentemente Năo sabe

\section{Socia}

4. Ele/ela alguma vez dirigiu carro?

5. Ele/ela dirige carros atualmente?

6. Se năo, é devido a problemas de memória ou pensamento (raciocínio)?

7. Se ele/ela ainda está dirigindo, há problemas ou riscos devido ao pensamento (raciocínio) pobre?
SIM NÄO

SIM NÄO

SIM NĀO

SIM NÄO

8. Ele/ela é capaz de fazer compras para suas próprias necessidades independentemente?

(precisa ser acompanhado (Pode comprar um número

em qualquer compra) limitado de itens, compra itens duplicados

ou esquece itens necessárice)

9. Ele/ela é capaz de fazer atividades independentemente fora de sua casa? Raramente ou nunca

Às vezes

Frequentemente

Năo sabe

(Freqüentemente incapaz de

(Atividades limitadas ou de rotina,

Participação significativa

realizar atividades sem ajuda) por exemplo,perticipaçăo superficia

em ativicades, por exemplo, votar na igreja ou reuniōes,ichas a
salăo de beleza).

10. Ele/ela é levado a eventos sociais fora da casa de familiares? Se năo, por que năo?

SIM NÄO

1. Um observador casual do comportamento do sujeito pensaria que ele está doente?

SIM NÃO

12. Se institucionalizado, ele/ela participa bem de atividades sociais?

SIM NÄO

IMPORTANTE:

As informaçōes coletadas são suficientes para classificar o nivel de comprometimento do sujeito em assuntos comunitários?

Se não, por favor, investique mais.

Atividades na comunidade: tais como ir à igreja, visitar amigos ou família, atividades políticas, organizaçöes profissionais tais como associaçöes, outros grupos profissionais, clubes sociais, organizaçăo de serviços, programas educacionais).

* Por favor, adicione notas se necessário para esclarecer o nivel de funcionamento do sujeito nesta área. 


\section{QUESTÕES SOBRE O LAR E ATIVIDADES DE LAZER PARA O INFORMANTE}

1a) Que mudanças ocorreram em suas habilidades de realizar tarefas domésticas?

1b) O que ele/ela ainda pode fazer bem?

2a) Que mudanças ocorreram em suas habilidades para realizar seus passatempos (hobbies)?

2b) $O$ que ele/ela ainda pode fazer bem?

3) Se institucionalizado, o que ele/ela năo pode mais fazer bem (Casa e Hobbies)

Atividades da vida diária (Blessed):

Nenhuma perda

4. Habilidade para realizar tarefas domésticas

Por favor, descreva
0

0,5

Perda grave

1

5. Ele/ela é capaz de realizar tarefas domésticas até o nivel de: (Escolha uma, o informante năo precisa ser perguntado diretamente)

\section{Sem funcăo significativa}

(Realiza atividades simples, tais como fazer a cama, somente com muita supervisăo)

Funciona somente em atividades limitadas

(Com alguma supervisăo, lava a louça com limpeza aceitável, coloca a mesa)

\section{Funciona independentemente em algumas atividades}

(Opera equipamentos, tal como aspirador de pó, prepara refeiçöes simples)

Funciona em atividades usuais mas não no nivel usual

Funciona normalmente em atividades usuais

\section{IMPORTANTE:}

As informaçōes coletadas são suficientes para classificar o nivel de comprometimento do sujeito em CASA \& HOBBIES?

\section{Se não, por favor investique mais.}

Tarefas Domésticas: Tais como cozinhar, lavar, limpar, fazer compras, levar o lixo para fora, limpar o quintal, manutençăo de cuidados básicos e reparos básicos na casa

Hobbies: Costurar, pintar, artesanato, leitura, entretenimento, fotografia, jardinagem, ir ao teatro ou concerto, trabalho em madeira, participaçăo em esportes. 
ESCORE CLÍNICO DE DEMÊNCIA (CDR)

\begin{tabular}{|l|l|l|l|l|l|}
\hline Escore Clínico de Demência (CDR) & 0 & 0,5 & 1 & 2 & 3 \\
\hline
\end{tabular}

\begin{tabular}{|c|c|c|c|c|c|}
\hline & \multicolumn{5}{|c|}{ Comprometimento } \\
\hline & $\begin{array}{c}\text { Normal } \\
0\end{array}$ & $\begin{array}{c}\text { Questionável } \\
0,5\end{array}$ & $\begin{array}{c}\text { Leve } \\
1\end{array}$ & $\begin{array}{c}\text { Moderada } \\
2\end{array}$ & $\begin{array}{c}\text { Grave } \\
3\end{array}$ \\
\hline Memória & $\begin{array}{l}\text { Sem perda de } \\
\text { memória ou } \\
\text { esquecimento leve e } \\
\text { inconstante. }\end{array}$ & $\begin{array}{l}\text { Esquecimento leve e } \\
\text { constante (em } \\
\text { oposiçăo a eventual); } \\
\text { recordaçăo parcial de } \\
\text { eventos; } \\
\text { esquecimento } \\
\text { "benigno". } \\
\end{array}$ & $\begin{array}{l}\text { Moderada perda de } \\
\text { memória; mais marcada } \\
\text { para eventos recentes; } \\
\text { déficit interfere nas } \\
\text { atividades cotidianas. }\end{array}$ & $\begin{array}{c}\text { Perda de memória } \\
\text { grave; somente retém } \\
\text { material intensamente } \\
\text { aprendido; material } \\
\text { novo rapidamente } \\
\text { perdido. }\end{array}$ & $\begin{array}{l}\text { Perda de memória } \\
\text { grave; restam } \\
\text { apenas fragmentos. }\end{array}$ \\
\hline Orientação & $\begin{array}{l}\text { Plenamente } \\
\text { orientado. }\end{array}$ & $\begin{array}{l}\text { Plenamente orientado, } \\
\text { exceto por leve } \\
\text { dificuldade nas } \\
\text { relaçöes temporais. }\end{array}$ & $\begin{array}{c}\text { Dificuldade moderada } \\
\text { com relaçöes } \\
\text { temporais; orientado } \\
\text { para lugar do exame; } \\
\text { pode ter desorientaçăo } \\
\text { geográfica em outros } \\
\text { lugares. } \\
\end{array}$ & \begin{tabular}{|c|} 
Dificuldade grave com \\
relaçöes temporais; \\
usualmente \\
desorientado para o \\
tempo, \\
frequentemente para o \\
espaço. \\
\end{tabular} & $\begin{array}{l}\text { Orientado apenas } \\
\text { para pessoa. }\end{array}$ \\
\hline $\begin{array}{l}\text { Julgamento } \\
\text { e resolução } \\
\text { de } \\
\text { problemas }\end{array}$ & $\begin{array}{c}\text { Resolve bem } \\
\text { problemas diários e } \\
\text { administra bem } \\
\text { negócios e finanças; } \\
\text { bom julgamento em } \\
\text { relaçăo ao } \\
\text { desempenho prévio. }\end{array}$ & $\begin{array}{l}\text { Leve dificuldade em } \\
\text { resolver problemas, } \\
\text { similaridades e } \\
\text { diferenças. }\end{array}$ & $\begin{array}{c}\text { Dificuldade moderada } \\
\text { para administrar } \\
\text { problemas, } \\
\text { similaridades e } \\
\text { diferenças; julgamento } \\
\text { social usualmente } \\
\text { mantido. } \\
\end{array}$ & $\begin{array}{l}\text { Grave dificuldade em } \\
\text { administrar problemas, } \\
\text { similaridades } e \\
\text { diferenças; julgamento } \\
\text { social usualmente } \\
\text { comprometido. }\end{array}$ & $\begin{array}{l}\text { Incapaz de fazer } \\
\text { julgamentos ou de } \\
\text { resolver problemas. }\end{array}$ \\
\hline $\begin{array}{l}\text { Assuntos } \\
\text { Comunitários }\end{array}$ & $\begin{array}{l}\text { Função } \\
\text { independente no } \\
\text { nível usual no } \\
\text { trabalho, em } \\
\text { compras, grupos } \\
\text { sociais ou de } \\
\text { voluntários. }\end{array}$ & $\begin{array}{l}\text { Leve dificuldade } \\
\text { nessas atividades }\end{array}$ & $\begin{array}{l}\text { Incapaz de funcionar } \\
\text { independentemente } \\
\text { nessas atividades, } \\
\text { embora ainda possa } \\
\text { engajar-se em algumas; } \\
\text { parece normal à } \\
\text { inspeçăo casual. }\end{array}$ & $\begin{array}{c}\text { Nenhuma referência a } \\
\text { funcionamento } \\
\text { independente fora de } \\
\text { casa. Parece estar } \\
\text { bem para ser levado a } \\
\text { atividades fora de } \\
\text { ambiente familiar. }\end{array}$ & $\begin{array}{l}\text { Nenhuma referência } \\
\text { a funcionamento } \\
\text { independente fora } \\
\text { de casa. Parece } \\
\text { estar muito doente } \\
\text { para ser levado a } \\
\text { atividades fora de } \\
\text { ambiente familiar } \\
\end{array}$ \\
\hline $\begin{array}{l}\text { Tarefas do } \\
\text { Lare } \\
\text { Atividades } \\
\text { de Lazer }\end{array}$ & $\begin{array}{l}\text { Vida no lar, } \\
\text { passatempos e } \\
\text { interesses } \\
\text { intelectuais bem } \\
\text { mantidos. }\end{array}$ & $\begin{array}{c}\text { Vida no lar, } \\
\text { passatempos e } \\
\text { atividades intelectuais } \\
\text { levemente } \\
\text { comprometidos. }\end{array}$ & $\begin{array}{c}\text { Dificuldade leve mas } \\
\text { evidente nas funçōes } \\
\text { do lar; tarefas mais } \\
\text { dificeis abandonadas; } \\
\text { passatempos e } \\
\text { interesses mais } \\
\text { complexos } \\
\text { abandonados. } \\
\end{array}$ & $\begin{array}{l}\text { Somente tarefas } \\
\text { simples preservadas, } \\
\text { interesses muito } \\
\text { restritos e mal } \\
\text { sustentados. }\end{array}$ & $\begin{array}{l}\text { Sem função } \\
\text { significativa em } \\
\text { casa. }\end{array}$ \\
\hline Autocuidado & Plenamente capaz & para o autocuidado. & Necessita estímulo. & $\begin{array}{c}\text { Requer ajuda para } \\
\text { vestir-se, higiene } e \\
\text { cuidado com objetos } \\
\text { pessoais. }\end{array}$ & $\begin{array}{c}\text { Requer muita ajuda } \\
\text { para o cuidado } \\
\text { pessoal, } \\
\text { incontinência } \\
\text { frequente. } \\
\end{array}$ \\
\hline
\end{tabular}


Inventário Neuropsiquiátrico

(Cummungs et al - 1994)

- Responder baseando-se nas mudanças que ocorreram desde que o paciente começou a ter problemas de memória

- Marcar sim apenas quando o sintoma estiver presente. Do contrário, marcar não.

- Responda honestamente e meticulosamente às questões

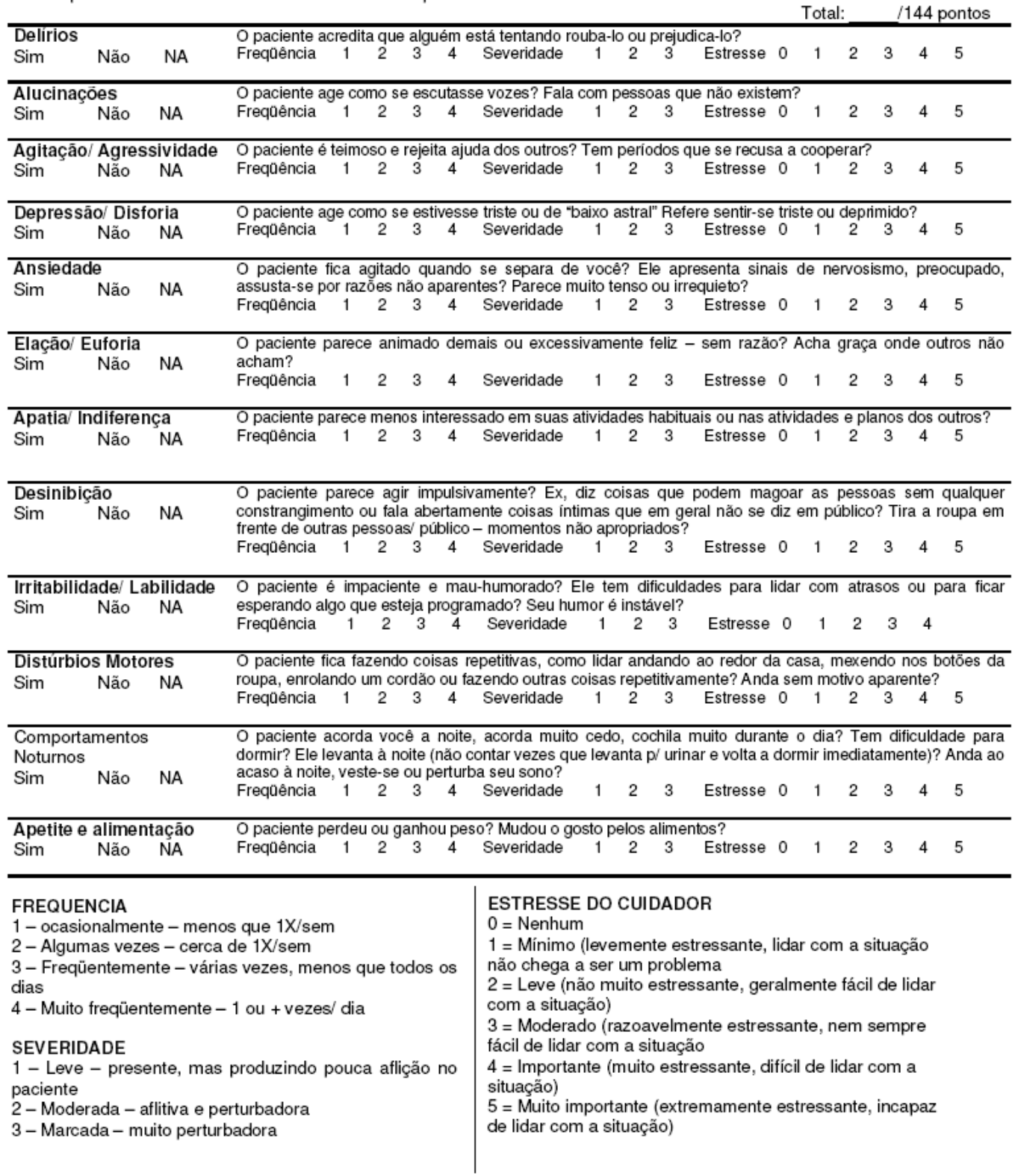


Índice de Katz para Atividades de Vida Diária

(Katz, S; Down, TD; Cash, HR et al - 1970)

\begin{tabular}{|l|l|}
\hline Banho & I - Independente - não necessita de auxílio \\
& A - Auxílio - recebe assistência para banhar uma parte do corpo (dorso/pernas) \\
D - Dependente - necessita que alguém o banhe
\end{tabular}

$\mathrm{I}=1$ ponto; $\mathrm{A}=0,5$ e $\mathrm{D}=0$ ponto

TOTAL: 16

Avaliação de Parkinsonismo (Adaptado de Tanner et al, 1990)

\begin{tabular}{|l|l|l|}
\hline & SIM & NÁO \\
\hline 1. Tinha dificuldade para se levantar de uma cadeira? & & \\
\hline 2. Notou se a letra (escrita) ficou pequena, se reduziu de tamanho? & & \\
\hline $\begin{array}{l}\text { 3. Notou ou alguém comentou se a sua voz estava mais baixa ou mais fraca } \\
\text { que era antes? }\end{array}$ & & \\
\hline 4. Tinha alterações do equilíbrio ao caminhar? & & \\
\hline 5. Os pés ficavam presos ou agarrados no chão ao atravessar portas? & & \\
\hline 6. Acha o seu rosto ficou mais "parado", menos expressivo do que era antes? & & \\
\hline 7. Tinha tremores nos braços ou nas pernas? & & \\
\hline 8. Tinha dificuldades de abotoar as roupas? & & \\
\hline 9. Arrastava os pés ou dava passos curtos ao caminhar? & \\
\hline
\end{tabular}

Não Aplicável Park: 
ESCALA DE ATIVIDADES INSTRUMENTAIS DA VIDA DIÁRIA (IADL)

(Lawton \& Brody)

\section{A - Habilidade para usa o telefone \\ 1. Utiliza o telefone por iniciativa própria \\ 2. Disca alguns números conhecidos \\ 3. Atende mas não faz ligaçōes \\ 4. Não usa o telefone de modo algum}

\section{B - Compras}

1. Faz compras independente/e

2. Faz pequenas compras independente/e

3. Precisa ser acompanhado nas compras

4. Incapaz de fazer compras

\section{C - Preparo de alimentos}

1. Planeja, prepara e serve adequadamente as refeiçōes independentemente

2. Prepara adequadamente as refeições se alguém Ihe fornecer os ingredientes

3. Aquece, serve e prepara refeições, mas não garante uma dieta adequada

4. Necessita que alguém prepare e sirva a refeição

\section{D - Tarefas domésticas}

1. Mantem a casa sozinho ou com auxilio ocasional (p.ex: auxílio para tarefas pesadas)

2. Realiza tarefas diárias leves, como lavar louça, fazer a cama

3. Realiza tarefas diárias leves, mas não consegue fazê-las dentro dos padrôes de limpeza

4. Necessita de auxílio com todas as tarefas domésticas

5. Não faz/ participa de nenhuma tarefa doméstica

\section{E - Lavanderia}

1. Lava completamente as roupas

2. Lava pequenas peças: meias, etc

3. Toda a roupa deve ser lavada por terceiros

\section{F - Transporte}

1. Usa independentemente transportes públicos ou dirige seu próprio carro

2. Chama de táxi, mas não usa transporte público 1

3. Usa transporte público se acompanhado

4. Locomove-se limitadamente de táxi ou carro com auxílio de outros

5. Não sai de casa/ Não usa nenhum transporte 0

\section{G - Medicação}

1. É responsável por tomar sua medicação em dose e horários corretos

2. Assume responsabilidade por tomar sua medicação se separada anteriormente por outros

3. Não é capaz de tomar sua medicação

\section{H - Finanças}

1. Controla suas finanças independentemente (conta de banco, talão de cheque, preenche cheques, paga contas)

2. Controla contas no dia a dia, mas necessita de 1 auxílio com banco, compras maiores,...

3. Incapaz de controlar finanças

Lawton,MP; Brody, EM - The instrumental activities of Daily Living Scale. Gerontologist, 1969, 9: 179 - 186

Perguntas adicionais:

Total: $/ 8$ pontos

Ele(a) esquece panela no fogo, torneira aberta ou ferro ligado?

Ele(a) pode ser deixado(a) em casa sozinho(a) de forma segura? 


\section{Episódio Maior Depressivo no Passado - SCID}

Critérios para classificar como depressão maior: Cinco (ou mais) dos seguintes critérios presentes durante período maior ou igual a duas semanas, sendo que um dos cinco deve ser ou (1) humor deprimido, ou (2) perda do interesse ou prazer.

1) Já houve, pelo menos uma vez na vida dele(a), algum momento em que se sentiu deprimido(a), ou na pior na maior parte do dia, quase todos os dias? (Como é que foi isso?)

SE SIM: Durou mais que duas semanas? SIM( ) NÃO( )

Critério: $12 \quad 3$

2) Naquele tempo ou em outro momento, ele(a) perdeu o interesse ou o prazer pelas coisas que costumava gostar? (Como é que foi isso?) Isso acontecia quase todos os dias?

SE SIM: Durou mais que duas semanas? SIM ( ) NÃO ( )

Critério: $1 \quad 2 \quad 3 \quad$ ? Quando foi isso?

3) Naquele período ele(a) perdeu ou ganhou peso? Ele(a) estava tentando perder peso?

SE NÂO: Como estava o apetite dele(a)? (Tinha que forçar para comer? Comia menos/mais que o habitual? Isso acontecia quase todos os dias?)

Critério $1 \quad 2 \quad 3 \quad$ ? Assinalar: Perda de peso ou redução do apetite___ Ganho de peso ou aumento do apetite 4) Como estava o sono dele(a)? (Dificuldade para dormir, acordando freqüentemente, dificuldades em ficar acordado, acordando muito cedo, ou, dormindo demais? Quantas horas por noite comparado com o habitual? Isso acontecia quase todas as noites?)

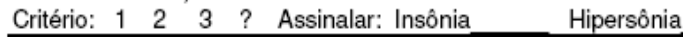

5) Ele(a) estava tão inquieto(a) ou agitado(a) que não era capaz de ficar parado(a)? (Isso acontecia todos os dias?)

SE NÃO: E o contrário: falando e se movendo mais devagar do que o normal dele(a)? (Isso acontecia todos os dias?)

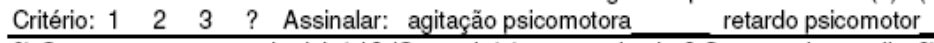

6) Como estava a energia dele(a)? (Cansado(a) o tempo inteiro? Quase todos os dias?)

Critério: $12 \quad 3 \quad$ ?

7) Como ele se sentia em relação a si mesmo? (Inútil, sem valor?) Quase todos os dias?

SE NÃO: Ele se sentia culpado por coisas que fazia ou deixava de fazer? Quase todos os dias?

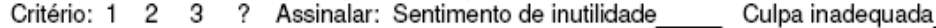

8) Ele(a) tinha dificuldade para se concentrar ou pensar? (Com que tipo de coisas isso interferia?) Quase todos os dias?

SE NĀO: Era difícil para ele(a) tomar decisöes sobre coisas do dia a dia? Quase todos os dias?

Critério: $1 \quad 2 \quad 3 \quad$ ? Assinalar: Capacidade de pensar diminuída_ Indecisão

9) As coisas estavam tão ruins que ele(a) pensava muito em morte ou que estaria em melhor situação se estivesse morto(a)? E quanto a se ferir?

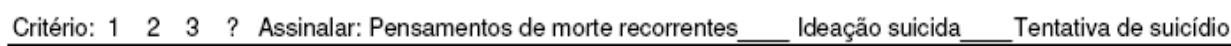

10) Durante aquele tempo ficou difícil para ele(a) trabalhar, cuidar das coisas em casa, ou se relacionar com as pessoas?

$\operatorname{SIM}() \mathrm{NA} O()$

11) Pouco antes de tudo isso começar ele estava bebendo em excesso ou usando drogas? SIM ( ) NÃO ( )

12) Pouco antes disso começar ele estava fisicamente doente? $\operatorname{SIM}($ ) NÃO ( )

13) Isso começou logo depois de alguém próximo a ele(a) morrer? SIM ( ) NÃO ( )

Durou mais que 2 meses? $\operatorname{SIM}($ ) NÃO ( )

OBS: Houve algum outro episódio de depressão na vida do paciente? ( ) SIM （ ) NÃO

Quando ocorreu (eram)?

CONSIDERAR:

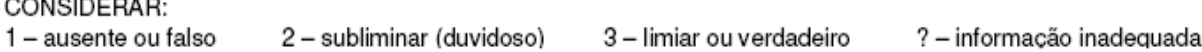




\section{Episódio Maníaco no Passado - SCID}

Critérios para classificar como mania no passado: Humor elevado e mais três dos outros sintomas, ou humor irritável e mais quatro dos outros sintomas.

HUMOR ELEVADO: Já houve algum período de tempo em ele(a) estava se sentindo tão bem, agitado(a) ou excitado(a) que vocês perceberam que ele(a) não estava no seu normal? Ou ficava tão excitado(a) que se envolvia em problemas? Critério $12{ }^{2} \quad 3$ ?

Durou pelo menos 1 semana? Ou ele(a) teve que procurar um hospital? Sim ( ) Não ( )

Quando foi isso?

HUMOR IRRITÁVEL: Houve algum período em que ele(a) estava tão irritado(a), que era pego(a) gritando com as pessoas ou começando brigas ou discussōes?

Durou mais que 1 semana? Ou ele(a) teve que procurar um hospital? Sim ( ) Não ( ) Critério: $12 \begin{array}{lll} & 2 & \end{array}$ ? Quando foi isso?

3) Naquele período como ele(a) se sentia em relação a si mesmo? (Mais confiante do que o habitual? Com algum poder ou habilidade especial?)

Critério 1253 ?

4) Naquele tempo ele(a) tinha que dormir menos que o habitual? (Mesmo assim se sentia descansado?)

Critério: 123 ?

5) Naquele tempo ele(a) estava muito mais falante que o habitual? (Vocês tinham dificuldade para interromper ou entender 0 que ele(a) estava falando?

Critério: 1203 ?

6) Naquele tempo os pensamentos passavam rapidamente pela cabeça dele(a)?

Critério: 123 ?

7) Naquele tempo ele(a) era tão facilmente distraído(a) por coisas a sua volta que tinha dificuldades para se concentrar ou continuar o que estava fazendo?

Critério: 123

8) Naquele período, como ele(a) passava o tempo? (Ele(a) se envolvia em tantas atividades a ponto de vocês ficarem preocupados?)

SE NÂO: Ele(a) estava fisicamente inquieto(a)? (Qual a intensidade disso?)

Critério: $1 \quad 2 \quad 3 \quad$ ? Assinalar: aumento na atividade $\quad$ agitação psicomotora

9) Naquele tempo, ele(a) fez alguma coisa que pudesse trazer problemas para ele(a) mesmo(a) ou para vocés (Comprando coisas que não precisava?) (Tendo comportamento sexual inadequado?)

Critério: $1 \begin{array}{llll}1 & 2 & 3 & \text { ? }\end{array}$

10) Durante aquele tempo ficou dificil para ele(a) trabalhar, cuidar das coisas em casa, ou se relacionar com as pessoas?

$\operatorname{SIM}($ ) NÄO ( )

11) Pouco antes de tudo isso começar ele(a) estava bebendo em excesso ou usando drogas?

SIM ( ) NÃO ( )

12) Pouco antes disso começar, ele(a) estava fisicamente doente?

$\operatorname{SIM}($ ) NÃO ( )

CONSIDERAR:

1 - ausente ou falso 2 -subliminar (duvidoso) 3 -limiar ou verdadeiro $\quad ?$-informação inadequada 
Transtorno Obsessivo-Compulsivo (TOC)

Seu parente alguma vez apresentou:

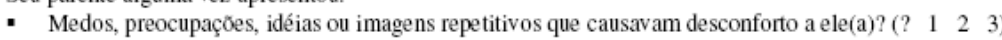

- Comportamentos repetitivos (manias) que a pessoa tinha que fazer várias vezes e não conseguia evitar, tais como (perguntar TODOS os itens de 1 a 9 ):

1) Verificar fechaduras, fogão, se não se feriu ou feriu outros, ou perguntar se foi responsável por algo terrível que tenha acontecido

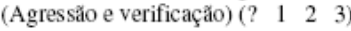

2) Lavar excessivamente mãos e objetos, tomar banhos demorados, parecer preocupado com sujeira ou micróbios, com ficar contaminado e adoecer por isso, ter nojo de secreçôes do próprio corpo (Contaminação, limpeza e lavagem) $(? l \quad 1 \quad 2 \quad 3)$

3) Guardar objetos inúteis, manter o quarto ou casa entulhados (Colecionamento) $\quad \begin{array}{llllll}\text { (? } & 1 & 2 & 3\end{array}$

4) Preocupação excessiva com: desrespeito a Deus; certo e errado; moralidade (Religião) $\quad$ (? 1 2 3 )

5) Mania de arrumação, simetria, exatidão, perfeccionismo, ter que deixar as coisas organizadas do seu jeito $\quad\left(\begin{array}{llllllllllll} & 1 & 2 & 3\end{array}\right.$

6) Preocupação excessiva com doenças sem ser por contaminação, com partes do corpo, com a aparência física: (? $1 \quad 2 \quad 3)$

7) Compulsóes de repetição, reler ou reescrever várias vezes, repetir atividades rotineiras como entrar e sair de casa, levantar-se da cadeira, vestir roupas) ( $\left.\begin{array}{llll}? & 1 & 2 & 3\end{array}\right)$

8) Compulsøes de contagem (contar telhas, tijolos, riscas do chão) (? 1 l 2 2 3)

9) Comportamentos extremamente supersticiosos (medo de passar perto de cemitérios, medo de gato preto, de números ou cores que representem azar). ( $\left(\begin{array}{llll}? & 1 & 2 & 3\end{array}\right)$

Qualquer um dos itens de 1 a 9 foi positivo? ? $13 \Rightarrow$ ? ou $1=$ pule para Transtornos de tiques;

3=continue abaixo:

Você acha que seu parente gastava muito tempo por dia com esses sintomas? $\quad\left(\begin{array}{llll}? & 1 & 2 & 3\end{array}\right)$

Quanto tempo? ______ (juntando tudo chegava a 1 hora por dia?) $\quad\left(\begin{array}{llll}? & 1 & 2 & 3\end{array}\right)$

Os sintomas interferiam na vida dele? $\left(\begin{array}{lllll}? & 1 & 2 & 3\end{array}\right)$

Causavam ansiedade, sofrimento? ( $\left.\begin{array}{lllll} & 1 & 2 & 3\end{array}\right)$ Com que idade os sintomas começaram?

\section{Transtornos de tiques}

Tiques, também chamados de sestos ou cacoetes, são movimentos involuntários (que a pessoa faz sem querer), que geralmente começam na infância. Podem ser motores ou vocais. Os principais exemplos são (mostrar exemplos): piscar os olhos, fazer caretas, colocar a língua para fora, sacudir os ombros, sacudir a cabeça, fungar, pigarrear, assoviar, estalar etc.

1) A pessoa tinha tiques motores ( $\left.\begin{array}{llll} & 1 & 2 & 3\end{array}\right)$ Idade de início:_____ Tipos de tiques:

2) Tinha tiques vocais ( $\left.\begin{array}{llll} & 1 & 2 & 3\end{array}\right)$ Idade de início: tipos de tiques:

Se Nào para as respostas 1 e 2, passe para o próximo questionário. Se Sim para alguma das respostas:

Os tiques duraram mais de um ano? (? 12 ( 23$)$

Os tiques duraram entre 3 meses e um ano? ( $\left.\begin{array}{llll}? & 1 & 2 & 3\end{array}\right)$

A pessoa tem tiques motores e vocais? (? $\left.1 l^{1} \quad 3\right)$

Outras informaçoes relevantes: 
CLASSIFICAÇÃO SÓCIO ECONÔMICA

Associação Brasileira dos Institutos de Pesquisa de Mercado

(ABIPEME)

A- Em sua casa tem?

\begin{tabular}{|l|l|l|c|c|c|c|c|c|}
\hline & \multirow{2}{*}{ NÃO } & \multirow{2}{*}{ SIM } & \multicolumn{6}{|c|}{ QUANTIDADE } \\
\cline { 4 - 9 } & & & $\mathbf{1}$ & $\mathbf{2}$ & 3 & $\mathbf{4}$ & $\mathbf{5}$ & $\mathbf{6}$ ou + \\
\hline Televisão & & & 2 & 4 & 6 & 8 & 10 & 12 \\
\hline Empregada mensalista & & & 6 & 12 & 18 & 24 & 24 & 24 \\
\hline Rádio & & & 1 & 2 & 3 & 4 & 5 & 6 \\
\hline Banheiro & & & 2 & 4 & 6 & 8 & 10 & 12 \\
\hline Aspirador de pó & & & 5 & 5 & 5 & 5 & 5 & 5 \\
\hline Máquina de lavar & & & 2 & 2 & 2 & 2 & 2 & 2 \\
\hline Automóvel de passeio & & & 4 & 8 & 16 & 16 & 16 & 16 \\
\hline
\end{tabular}

TOTAL:

B- Qual a instrução do chefe de familia? (Quem é o chefe da família:

\begin{tabular}{|l|c|}
\hline Sem Instrução/ primário incompleto & 0 \\
\hline Primário completo/ ginásio incompleto & 1 \\
\hline Ginásio completo/ colegial incompleto & 3 \\
\hline Colegial completo/superior incompleto & 5 \\
\hline Superior completo & 10 \\
\hline
\end{tabular}

TOTAL:

\begin{tabular}{|c|c|}
\hline \multicolumn{2}{|c|}{ CLASSE ABIPEME } \\
\hline CLASSE & PONTOS \\
\hline A & 35 OU + \\
\hline B & 21 a 34 \\
\hline C & 10 a 20 \\
\hline D & 05 a 09 \\
\hline E & 00 a 04 \\
\hline
\end{tabular}


9. REFERÊNCIAS 
Aaltonen KE, Ebbesson A, Wigerup C, Hedenfalk I. Laser capture microdissection (LCM) and whole genome amplification (WGA) of DNA from normal breast tissue---optimization for genome wide array analyses. BMC Res Notes. 2011;4(1):69.

Adahchour M, Brandt M, Baier HU, Vreuls RJ, Batenburg AM, Brinkman UAT. Comprehensive two-dimensional gas chromatography coupled to a rapidscanning quadrupole mass spectrometer: principles and applications. $J$ Chromatogr A. 2005;1067(1):245-254.

Aebersold R, Mann M. Mass spectrometry-based proteomics. Nature. 2003; 422(6928):198-207.

Ahram M, Flaig MJ, Gillespie JW, Duray PH, Linehan WM, Ornstein DK, et al. Evaluation of ethanol-fixed, paraffin-embedded tissues for proteomic applications. Proteomics. 2003;3(4):413-421.

Alberio T, Bossi AM, Milli A, Parma E, Gariboldi MB, Tosi G, et al. Proteomic analysis of dopamine and a-synuclein interplay in a cellular model of Parkinson's disease pathogenesis. FEBS J. 2010;277(23):4909-4919.

Altelaar, AF, Heck AJ. Trends in ultrasensitive proteomics. Curr Opin Chem Biol. 2012;16(1):206-213.

Altelaar, AF, Munoz J, Heck AJ. Next-generation proteomics: towards an integrative view of proteome dynamics. Nat Rev Genet. 2013;14(1):35-48.

Andersson M, Groseclose MR, Deutch AY, Caprioli RM. Imaging mass spectrometry of proteins and peptides: 3D volume reconstruction. Nature Methods. 2008;5(1):101-108

Banks RE, Dunn MJ, Forbes MA, Stanley A, Pappin D, Naven T, et al. The potential use of laser capture microdissection to selectively obtain distinct populations of cells for proteomic analysis-preliminary findings. Electrophoresis. 1999;20(4-5):689-700.

Begcevic I, Kosanam H, Martínez-Morillo E, Dimitromanolakis A, Diamandis P, Kuzmanov U, et al. Semiquantitative proteomic analysis of human hippocampal tissues from Alzheimer's disease and age-matched control brains. Clin Proteomics. 2013;10(1):5.

Bekris LM, Mata IF, Zabetian CP. The genetics of Parkinson disease. J Geriatr Psychiatry Neurol. 2010;23(4):228-242.

Bevilacqua C, Makhzami S, Helbling JC, Defrenaix P, Martin P. Maintaining RNA integrity in a homogeneous population of mammary epithelial cells isolated by Laser Capture Microdissection. BMC cell biology. 2010;11(1):95. 
Bisaglia M, Tessari I, Mammi S, Bubacco L. Interaction between a-synuclein and metal ions, still looking for a role in the pathogenesis of Parkinson's disease. Neuromolecular Med. 2009; 11(4):239-251.

Boggio KJ, Obasuyi E, Sugino K, Nelson SB, Agar NY, Agar JN. Recent advances in single-cell MALDI mass spectrometry imaging and potential clinical impact. Expert Rev Proteomics. 2011;8(5):591-604.

Boone DR, Sell SL, Hellmich HL. Laser capture microdissection of enriched populations of neurons or single neurons for gene expression analysis after traumatic brain injury. J Vis Exp. 2013;(74).

Bonner RF, Emmert-Buck M, Cole K, Pohida T, Chuaqui R, Goldstein S, et al. Laser capture microdissection: molecular analysis of tissue. Science. 1997;278:1481-1483.

Braak H, Braak E. Neuropathological stageing of Alzheimer-related changes. Acta Neuropathol. 1991;82(4):239-259.

Braak $\mathrm{H}$, Braak E. Nuclear configuration and neuronal types of the nucleus niger in the brain of the human adult. Human neurobiol. 1985;5(2):71-82.

Braak H, Ghebremedhin E, Rüb U, Bratzke H, Del Tredici K. Stages in the development of Parkinson's disease-related pathology. Cell Tissue Res. 2004; 318(1):121-134.

Brown RC, Lockwood AH, Sonawane BR. Neurodegenerative diseases: an overview of environmental risk factors. Environ Health Persp. 2005;1250-1256.

Buckanovich RJ, Sasaroli D, O'Brien-Jenkins A, Botbyl J, Conejo-Garcia JR, Benencia, F. Use of immuno-LCM to identify the in situ expression profile of cellular constituents of the tumor microenvironment. Cancer Biol Ther. 2006;5(6):635-642.

Burgemeister R, Gangnus R, Haar B, Schütze K, Sauer U. High quality RNA retrieved from samples obtained by using LMPC (laser microdissection and pressure catapulting) technology. Pathology Res. 2003;199(6):431-436.

Burnet PWJ, Eastwood SL, Harrison PJ. Laser-assisted microdissection: methods for the molecular analysis of psychiatric disorders at a cellular resolution. Bio psychiatry. 2004;55(2):107-111.

Cabello CR, Thune JJ, Pakkenberg H, Pakkenberg B. Ageing of substantia nigra in humans: cell loss may be compensated by hypertrophy. Neuropathol Appl Neurobiol. 2002;28(4):283-291.

Caldwell RL; Caprioli RM. Tissue profiling by mass spectrometry: A review of methodology and applications. Mol \& Cell Proteomics. 2005;4(4):394-401. 
Carvalho JAMD e Garcia RA. O envelhecimento da populaçäo brasileira: um enfoque demográfico. Cad. saúde pública. 2003;19(3):725-733.

Caudle WM, Pan S, Shi M, Quinn T, Hoekstra J, Beyer RP, et al. Proteomic identification of proteins in the human brain: Towards a more comprehensive understanding of neurodegenerative disease. Proteomics Clin Appl. 2008; 2(10-11):1484-1497.

Cermelli C, Berti R, Soldan, SS, Mayne M, James, M, Ludwin SK, et al. High frequency of human herpesvirus 6 DNA in multiple sclerosis plaques isolated by laser microdissection. J Infect Dis. 2003;187(9):1377-1387.

Chaurand P, Norris JL, Cornett DS, Mobley JA, Caprioli RM. New developments in profiling and imaging of proteins from tissue sections by MALDI mass spectrometry. J Proteome Res. 2006; 5(11):2889-2900.

Chaurand P, Schwartz SA, Billheimer D, Xu BJ, Crecelius A, Caprioli RM. Integrating histology and imaging mass spectrometry. Anal Chem. 2004;76(4):1145-1155.

Chen HW, Hu B, Zhang X. Principle and application of ambient mass spectrometry for direct analysis of complex samples. Chinese $J$ Anal Chem. 2010;38(8):1069-1088.

Chinta SJ, Andersen JK. Dopaminergic neurons. Int J Biochem Cell Biol. 2005; $37(5): 942-946$.

Chowdhuri SR, Xi L, Pham THT, Hanson J, Rodriguez-Canales J, Berman A, et al. EGFR and KRAS mutation analysis in cytologic samples of lung adenocarcinoma enabled by laser capture microdissection. Mod Pathol. 2012;25(4), 548-555.

Chung SH, Shen W. Laser capture microdissection: from its principle to applications in research on neurodegeneration. Neural Regener Res. 2015;10(6):897.

Clément-Ziza M, Munnich A, Lyonnet S, Jaubert F, Besmond C. Stabilization of RNA during laser capture microdissection by performing experiments under argon atmosphere or using ethanol as a solvent in staining solutions. Rna. 2008; 14(12):2698-2704.

Cossette $M$, Lévesque $M$, Parent $A$. Extrastriatal dopaminergic innervation of human basal ganglia. Neurosci res. 1999;34(1):51-54.

Cowen D. The melanoneurons of the human cerebellum (nucleus pigmentosus cerebellaris) and homologues in the monkey. $J$ Neuropathol Exp Neurol. 1986;45(3):205. 
Craven RA; Banks RE. Laser capture microdissection and proteomics: possibilities and limitation. Proteomics. 2001;1(10):1200-1204.

Craven RA, Totty N, Harnden P, Selby PJ, Banks RE. Laser capture microdissection and two-dimensional polyacrylamide gel electrophoresis: evaluation of tissue preparation and sample limitations. Am $J$ Pathol. $2002 ; 160(3): 815-822$.

Cummings M, McGinley CV, Wilkinson N, Field SL, Duffy SR, Orsi NM. A robust RNA integrity-preserving staining protocol for laser capture microdissection of endometrial cancer tissue. Anal Biochem. 2011;416(1):123-125.

Curran S, McKay JA, McLeod HL, Murray Gl. Laser capture microscopy. Mol Pathol. 2000; 53(2):64.

Curran S, Murray Gl. Tissue microdissection and its applications in pathology. Current Diagn Pathol. 2002;8(3):183-192.

Damier P, Hirsch EC, Agid Y, Graybiel AM. The substantia nigra of the human brain I. Nigrosomes and the nigral matrix, a compartmental organization based on calbindin D28K immunohistochemistry. Brain. 1999a;122: 1421-1436.

Damier P, Hirsch EC, Agid Y, Graybiel AM. The substantia nigra of the human brain II. Patterns of loss of dopamine-containing neurons in Parkinson's disease. Brain. 1999b;122:1437-1448.

Datta S, Malhotra L, Dickerson R, Chaffee S, Sen CK, Roy S. Laser capture microdissection: Big data from small samples. Histol Histopathol. 2015;1162211622.

Dauguet J, Delzescaux T, Condé F, Mangin JF, Ayache N, Hantraye P, Frouin $\mathrm{V}$. Three-dimensional reconstruction of stained histological slices and 3D nonlinear registration with in-vivo MRI for whole baboon brain. J Neurosci Methods. 2007;164(1):191-204.

DeCarlo K, Emley A, Dadzie OE, e Mahalingam, M. Laser capture microdissection: methods and applications. In Laser Capture Microdissection (pp. 1-15). Humana Press. 2011.

Dembinsky D, Woll K, Saleem M, Liu Y, Fu Y, Borsuk LA, et al. Transcriptomic and proteomic analyses of pericycle cells of the maize primary root. Plant physiology. 2007;145(3):575-588.

De Souza Al, McGregor E, Dunn MJ, Rose ML. Preparation of human heart for laser microdissection and proteomics. Proteomics. 2004;4(3):578-586.

Dickson DW. Linking selective vulnerability to cell death mechanisms in Parkinson's disease. Am J Pathol. 2007;170(1):16-19. 
Double KL. Neuronal vulnerability in Parkinson's disease. Parkinsonism Relat Disord. 2012;18:S52-S54.

Double KL, Reyes S, Werry EL, Halliday GM. Selective cell death in neurodegeneration: Why are some neurons spared in vulnerable regions? Prog Neurobiol. 2010; 92:316-329

Dos Santos A, Thiers V, Sar S, Derian N, Bensalem N, Yilmaz F, et al. Contribution of laser microdissection-based technology to proteomic analysis in hepatocellular carcinoma developing on cirrhosis. Proteomics Clin Appl. 2007;1(6):545-554.

Eltoum IA; Siegal GP; Frost, A. R. Microdissection of histologic sections: past, present, and future. Adv Anat Pathol. 2002;9(5):316-322.

Emmert-Buck MR, Bonner RF, Smith PD, Chuaqui RF, Zhuang Z, Goldstein S R, et al. Laser capture microdissection. Science. 1996;274(5289):998-1001.

Farfel JM, Nitrini R, Suemoto CK, Grinberg LT, Ferretti REL, Leite REP, et al. Very low levels of education and cognitive reserve. A clinicopathologic study. Neurology. 2013;81(7):650-657.

Farley AR, Link AJ. Identification and quantification of protein posttranslational modifications. Method Enzymol. 2009;463:725-763.

Farooqui T, Farooqui AA. Aging: an important factor for the pathogenesis of neurodegenerative diseases. Mech Ageing Dev. 2009;130(4):203-215.

Fasano M, Bergamasco B, Lopiano L. Is neuromelanin changed in Parkinson's disease? Investigations by magnetic spectroscopies. J Neural Transm. 2006;113(6):769-774

Fearnley JM, Lees AJ. Ageing and Parkinson's disease: substantia nigra regional selectivity. Brain. 1991;114(5):2283-2301.

Fedorow H, Tribl F, Halliday G, Gerlach M, Riederer P, Double K. Neuromelanin in human dopamine neurons: comparison with peripheral melanins and relevance to Parkinson's disease. Prog Neurobiol. 2005;75(2):109-124.

Fend F, Emmert-Buck MR, Chuaqui R, Cole K, Lee J, Liotta LA, et al. ImmunoLCM: laser capture microdissection of immunostained frozen sections for mRNA analysis. Am J Pathol. 1999;154(1):61-66.

Fend F, Kremer M, Quintanilla-Martinez L. Laser capture microdissection: methodical aspects and applications with emphasis on immuno-laser capture microdissection. Pathobiology. 2000;68(4-5):209-214. 
Fend F, Raffeld M. Laser capture microdissection in pathology. J Clin Pathol. 2000;53(9):666-672.

Ferrer I, Armstrong J, Capellari S, Parchi P, Arzberger T, Bell J, et al. Effects of formalin fixation, paraffin embedding, and time of storage on DNA preservation in brain tissue: a BrainNet Europe study. Brain pathol. 2007;17(3):297-303.

Ferretti REDL, Grinberg LT, Leite REP, Farfel JM, Pasqualucci CAG, Nitrini R, et al. Banco de encéfalos humanos: uma ferramenta importante para o estudo do envelhecimento cerebral; Banco de encéfalos humanos: una herramienta importante para el estudio del envejecimiento del cerebro. Mundo saúde. 2009;33(1):89-98.

Fischer F, Wolters D, Rögner M, Poetsch A. Toward the Complete Membrane Proteome High Coverage of Integral Membrane Proteins Through Transmembrane Peptide Detection. Mol \& Cell Proteomics. 2006;5(3):444-453.

Gardaneh M. Dopamine-synthesizing neurons: An overview of their development and application for cell therapy. Iran J Biotechnol. 2010;8(8).

Giatti L, Barreto SM. Saúde, trabalho e envelhecimento no Brasil. Cad de Saúde Pública. 2003;19(3):759-771.

Gibb WR. Neuropathology of the substantia nigra. Neurology. 1991;31(1):48-59.

Gibb WR, Lees AJ. Anatomy, pigmentation, ventral and dorsal subpopulations of the substantia nigra, and differential cell death in Parkinson's disease. $J$ Neurol Neurosurg Psychiatry. 1991;54(5):388-396.

Ginsberg SD, Che S. Combined histochemical staining, RNA amplification, regional, and single cell cDNA analysis within the hippocampus. Lab invest. 2004;84(8):952-962.

Goldsworthy SM, Stockton PS, Trempus CS, Foley JF, Maronpot RR. Effects of fixation on RNA extraction and amplification from laser capture microdissected tissue. Mol Carcinog. 1999;25(2):86-91.

González-Fernández R, Prats E, Jorrín-Novo JV. Proteomics of plant pathogenic fungi. Biomed Res Int. 2010;2010.

Grinberg LT, Ferretti RE, Farfel JM, Leite R, Pasqualucci CA, Rosemberg S, et al. Brain bank of the Brazilian aging brain study group - a milestone reached and more than 1,600 collected brains. Cell Tissue Bank. 2007;8(2):151-62.

Grinberg LT, Rueb U, Heinsen $H$. Brainstem: neglected locus in neurodegenerative diseases. Front Neurol. 2011;(2):42. 
Gründemann J, Schlaudraff F, Haeckel O, Liss B. Elevated a-synuclein mRNA levels in individual UV-laser-microdissected dopaminergic substantia nigra neurons in idiopathic Parkinson's disease. Nucleic Acids Res. 2008;36(7):38.

Guatteo E, Cucchiaroni ML, Mercuri NB. Substantia nigra control of basal ganglia nuclei. J Neural Transm Suppl. 2009;(73):91-101.

Guo T, Wang W, Rudnick PA, Song T, Li J, Zhuang Z, et al. Proteome analysis of microdissected formalin-fixed and paraffin-embedded tissue specimens. $J$ Histochem Cytochem. 2007;55(7):763-772.

Gupta N, Hixson KK, Culley DE, Smith RD, Pevzner PA. Analyzing protease specificity and detecting in vivo proteolytic events using tandem mass spectrometry. Proteomics. 2010;10(15):2833-2844.

Gutstein HB, Morris JS. Laser capture sampling and analytical issues in proteomics. Expert Rev Proteomics. 2007;4(5):627-637.

Györkey F, Min KW, Huff JA, Györkey P. Zinc and magnesium in human prostate gland: normal, hyperplastic, and neoplastic. Cancer Res. 1967;27(8) Part 1:1348-1353.

Hao P, Ren Y, Alpert AJ, e Sze SK. Detection, evaluation and minimization of nonenzymatic deamidation in proteomic sample preparation. Molecular \& Cellular Proteomics. 2011;10(10):0111-009381.

He J, Zhu J, Liu Y, Wu J, Nie S, Heth JA, et al. Immunohistochemical staining, laser capture microdissection, and filter-aided sample preparation-assisted proteomic analysis of target cell populations within tissue samples. Electrophoresis. 2013;34(11):1627-1636.

Healy DG, Falchi M, O'Sullivan SS, Bonifati V, Durr A, Bressman S, International LRRK2 Consortium. Phenotype, genotype, and worldwide genetic penetrance of LRRK2-associated Parkinson's disease: a case-control study. Lancet Neurol. 2008;7(7):583-590.

Heinsen H. Serial Thick, Frozen, Gallocyanin Stained Sections of Human Centrl Nervous System. J Histotechnol. 1991;14(3):167-173.

Heinsen $\mathrm{H}$, Arzberger T, Schmitz C. Celloidin mounting (embedding without infiltration)-a new, simple and reliable method for producing serial sections of high thickness through complete human brains and its application to stereological and immunohistochemical investigations. J Chem Neuroanat. $2000 ; 20(1): 49-59$.

Helling S, Hüttemann M, Kadenbach B, Ramzan R, Vogt S, Marcus $\mathrm{K}$. Discovering the phosphoproteome of the hydrophobic cytochrome c oxidase membrane protein complex. In: Methods in Proteomics. Humana Press. 2012. 345-358. 
Hirsch EC, Faucheux B, Damier P, Mouatt-Prigent A, Agid Y. Neuronal vulnerability in Parkinson's disease. In: Adv Res Neurodegener. Springer Vienna. 1997. 79-88.

Ho CS, Lam CWK, Chan MHM, Cheung RCK, Law LK, Lit LCW, et al. Electrospray ionisation mass spectrometry: principles and clinical applications. Clin Biochem Ver. 2003; 24(1):3.

Hodge GK, Butcher LL. Pars compacta of the substantia nigra modulates motor activity but is not involved importantly in regulating food and water intake. Naunyn Schmiedebergs Arch Pharmacol. 1980;313(1):51-67.

Hoffmann E. Mass spectrometry. John Wiley \& Sons, Inc. 1996.

Hommel JD, Sears RM, Georgescu D, Simmons DL, DiLeone RJ. Local gene knockdown in the brain using viral-mediated RNA interference. Nature. 2003;9(12):1539-1544.

Hommerson P, Khan AM, de Jong GJ, Somsen GW. Ionization techniques in capillary electrophoresis-mass spectrometry: Principles, design, and application. Mass Spectrom Rev. 2011;30(6):1096-1120.

Hood BL, Darfler MM, Guiel TG, Furusato B, Lucas DA, Ringeisen BR, et al. Proteomic analysis of formalin-fixed prostate cancer tissue. Mol \& Cell Proteomics. 2005;4(11):1741-1753.

Hood BL, Conrads TP, Veenstra TD. Mass spectrometric analysis of formalin-fixed paraffin-embedded tissue: Unlocking the proteome within. Proteomics. 2006;6(14):4106-4114.

Instituto Brasileiro de Geografia e Estatística (IBGE). Perfil dos idosos responsáveis pelo domicílio no Brasil - 2000. Estudos e Pesquisas Informação Demográfica e Socioeconômica. Rio de Janeiro: IBGE; 2002.

Instituto Brasileiro De Geografia e Estatística (IBGE). Projeção da população do Brasil por sexo e idade 1980-2050 (Revisão 2008). Estudos e Pesquisas Informação Demográfica e Socioeconômica. Rio de Janeiro: IBGE. 2008.

Instituto Brasileiro de Geografia e Estatística (IBGE). Projeção da população do brasil. por sexo e idade para o período 2000/2060. Rio de Janeiro: IBGE. 2013.

Jenco JM, Rawlingson A, Daniels B, Morris AJ. Regulation of phospholipase D2: selective inhibition of mammalian phospholipase $D$ isoenzymes by $\alpha$-and $\beta$ synucleins. Biochemistry. 1998;37(14):4901-4909.

Jensen E. Laser-Capture Microdissection. Anat Rec. 2013;296(11):1683-1687. 
Jorgensen N, Cabanas M, Oliva J, Rejas J, Leon T. [The cost of informal care associated to incapacitating neurological disease having high prevalence in Spain]. Neurologia (Barcelona, Spain). 2007;23(1):29-39.

Karlsson $\mathrm{O}$ e Lindquist NG. Melanin affinity and its possible role in neurodegeneration. J Neural Transm. 2013;120(12):1623-1630.

Kato-Narita EM, Nitrini R e Radanovic M. Assessment of balance in mild and moderate stages of Alzheimer's disease: implications on falls and functional capacity. Arq Neuropsiquiatr. 2011;69(2A):202-207.

Kerk NM, Ceserani T, Tausta SL, Sussex IM, Nelson TM. Laser capture microdissection of cells from plant tissues. Plant Physiology. 2003;132(1):27-35.

Kirana C, Ward T, Jordan TW, Rawson P, Royds J, Shi HJ, Hood K. Compatibility of toluidine blue with laser microdissection and saturation labeling DIGE. Proteomics. 2009;9(2):485-490.

Kitsou E, Pan S, Zhang J, Shi M, Zabeti A, Dickson D, et al. Identification of proteins in human substantia nigra. Proteomics Clin Appl. 2008;2(5):776-782.

Kretzschmar $\mathrm{H}$. Brain banking: opportunities, challenges and meaning for the future. Nat Rev Neurosci. 2008;10(1):70-78.

Kubis N, Faucheux BA, Ransmayr G, Damier P, Duyckaerts C, Henin D, et al. Preservation of midbrain catecholaminergic neurons in very old human subjects. Brain. 2000;123(2):366-373.

Kulkarni BB, Powe DG, Hopkinson A, Dua HS. Optimised laser microdissection of the human ocular surface epithelial regions for microarray studies. BMC Ophthalmol. 2013;13(1):62.

Kumar A, Gibbs JR, Beilina A, Dillman A, Kumaran R, Trabzuni D, et al. Ageassociated changes in gene expression in human brain and isolated neurons. Neurobiol Aging. 2013;34(4):1199-1209.

Kummari E, Guo-Ross SX, Eells JB. Laser Capture Microdissection-A Demonstration of the Isolation of Individual Dopamine Neurons and the Entire Ventral Tegmental Area. JoVE. 2015;(96):52336.

Lawrie LC, Curran S, McLeod HL, Fothergill JE, Murray GI Application of laser capture microdissection and proteomics in colon cancer. Mol. Plant Pathol. $2001 ; 54(4): 253$.

Lee JE, Kwon J, Baek MC. A combination method of chemical with enzyme reactions for identification of membrane proteins. Biochim Biophys Acta. 2011; 1814(3):397-404. 
Leme LEG. O envelhecimento. Editora Contexto. São Paulo. 1997.

Liao H, Wu J, Kuhn E, Chin W, Chang B, Jones MD, et al. Use of mass spectrometry to identify protein biomarkers of disease severity in the synovial fluid and serum of patients with rheumatoid arthritis. Arthritis Rheum. 2004;50(12):3792-3803.

Lindquist NG, Larsson BS, Lydén-Sokolowski A. Neuromelanin and its possible protective and destructive properties. Pigm Cell Res. 1987;1(3):133-136.

López-Ferrer D, Petritis K, Lourette NM, Clowers B, Hixson KK, Heibeck T, et al. Fast On-Line Digestion System for Protein Characterization. Anal Chem. 2008;80(23):8930-8936.

Lotharius J, Brundin P. Pathogenesis of Parkinson's disease: dopamine, vesicles and $\alpha$-synuclein. Nat Rev Neurosci. 2002;3(12):932-942.

Louris JN, Cooks RG, Syka JE, Kelley PE, Stafford Jr GC, Todd JF. Instrumentation, applications, and energy deposition in quadrupole ion-trap tandem mass spectrometry. Anal Chem. 1987;59(13):1677-1685.

Mariani E, Polidori MC, Cherubini A, Mecocci P. Oxidative stress in brain aging, neurodegenerative and vascular diseases: an overview. J Chromatogr $B$. 2005;827(1):65-75.

Marié, RM. Defer GL. Working memory and dopamine: clinical and experimental clues. Curr Opin Neurol. 2003;16:S29-S35.

McAuley JH. The physiological basis of clinical deficits in Parkinson's disease. Prog Neurobiol. 2003;69(1):27-48.

McGeer PL, McGeer EG, Suzuki JS. Aging and extrapyramidal function. Arch Neurol. 1977;34(1):33-35.

McKeith IG, Galasko D, Kosaka K, Perry EK, Dickson DW, Hansen LA, et al. Consensus guidelines for the clinical and pathologic diagnosis of dementia with Lewy bodies (DLB): report of the consortium on DLB international workshop. Neurology. 1996;47(5):1113-24.

McRitchie DA, Halliday GM, Cartwright $\mathrm{H}$. Quantitative analysis of the variability of substantia nigra pigmented cell clusters in the human. Neuroscience. 1995; 68(2):539-551.

McRitchie DA, Hardman CD, Halliday GM. Cytoarchitectural distribution of calcium binding proteins in midbrain dopaminergic regions of rats and humans. J Comp Neurol. 1996;364(1):121-150.

Mittel CS. Parkinson's Disease: Overview and Current Abstracts. Nova Publishers. 2003. 
Mikulowska-Mennis A, Taylor TB, Vishnu P, Michie SA, Raja R, Horner N, Kunitake ST. High-quality RNA from cells isolated by laser capture microdissection. Biotechniques. 2002;33(1):176-179.

Mirra SS, Heyman A, Mckeel D, Sumi SM, Crain BJ, Brownlee LM, et al. The Consortium to Establish a Registry for Alzheimer's Disease (CERAD). Part II. Standardization of the neuropathologic assessment of Alzheimer's disease. Neurology. 1991;41(4):479-86.

Morris JC. The Clinical Dementia Rating (CDR): current version and scoring rules. Neurology. 1993;43(11):2412-4.

Mouledous L, Hunt S, Harcourt R, Harry JL, Williams KL, Gutstein HB. Proteomic analysis of immunostained, laser-capture microdissected brain samples. Electrophoresis. 2003;24(1-2):296-302.

Muangpaisan W, Mathews A, Hori H, Seidel D. A systematic review of the worldwide prevalence and incidence of Parkinson's disease. J Med Assoc Thai. $2011 ; 94(6): 749-55$.

Mukherjee S, Rodriguez-Canales J, Hanson J, Emmert-Buck MR, Tangrea MA, Prieto DA, et al. Proteomic analysis of frozen tissue samples using laser capture microdissection. In Proteomics for Biomarker Discovery Humana Press. 2013;71-83.

Murakami H, Liotta L, Star, RA. IF-LCM: laser capture microdissection of immunofluorescently defined cells for mRNA analysis. Kidney Int. 2000;58(3):1346-1353.

Murray Gl. An overview of laser microdissection technologies. Acta Histochem. 2007;109(3):171-176.

Murray GI, Curran S. Laser Capture Microdissection. Methods Mol Biol. 2005;293.

Mustafa A, Cenayko C, Mitry RR, Quaglia A. Laser microdissection microscopy: application to cell culture. In Human Cell Culture Protocols). Humana Press. 2012;385-392.

Muthane U, Yasha TC, Shankar SK. Low numbers and no loss of melanized nigral neurons with increasing age in normal human brains from India. Ann Neurol. 1998;43(3):283-287.

National Institute of Neurological Disorders and Stroke (NINDS) of National Institutes of Health (NIH). Parkinson's Disease: Hope Through Research. 2015. 
Nelson PT, Head E, Schmitt FA, Davis PR, Neltner JH, Jicha GA, et al. Alzheimer's disease is not "brain aging": neuropathological, genetic, and epidemiological human studies. Acta neuropathologica. 2011;121(5):571-587.

Obeso JA, Rodriguez-Oroz MC, Stamelou M, Bhatia KP e Burn DJ. The expanding universe of disorders of the basal ganglia. The Lancet. 2014;384(9942):523-531.

Ordway GA, Szebeni A, Duffourc MM, Dessus-Babus S, Szebeni K. Gene expression analyses of neurons, astrocytes, and oligodendrocytes isolated by laser capture microdissection from human brain: detrimental effects of laboratory humidity. J Neurosci Res. 2009;87(11):2430-243.

Organização das Nações Unidas (ONU). World Population Ageing, 1950-2050. Divisão Populacional da Organização das Nações Unidas. New York. United States. 2002.

Organização das Nações Unidas (ONU). Department of Economic and Social Affairs, Population Division. World Population Prospects: The 2012 Revision, Highlights and Advance Tables. 2013.

Organização das Nações Unidas (ONU). Department of Economic and Social Affairs, Population Division. Population Facts. 2014.

Parent M, e Parent A. Substantia nigra and Parkinson's disease: a brief history of their long and intimate relationship. Can J Neurol Sci. 2010;37(03):313-319.

Park JJ, Cunningham MG. Thin sectioning of slice preparations for immunohistochemistry. J Vis Exp. 2007;3(194).

Perlmutter MA, Best CJ, Gillespie JW, Gathright Y, González S, Velasco A, et al. Comparison of snap freezing versus ethanol fixation for gene expression profiling of tissue specimens. J Mol Diagn. 2004;6(4):371-377.

Pietersen CY, Lim MP, Macey L, Woo TUW, Sonntag KC. Neuronal typespecific gene expression profiling and laser-capture microdissection. In: Laser Capture Microdissection. Humana Press. 2011:327-343.

Pietersen CY, Lim MP, Woo TUW. Obtaining high quality RNA from single cell populations in human postmortem brain tissue. J Vis Exp. 2009(30).

Plum S, Helling S, Theiss C, Leite, REP, May C, Jacob-Filho W, et al. Combined enrichment of neuromelanin granules and synaptosomes from human substantia nigra pars compacta tissue for proteomic analysis. $J$ Proteomics. 2013;94:202-206.

Qu C, De Ronchi D, Fratiglioni L. The epidemiology of the dementias: an update. Curr Opin Psychiatr. 2007;20(4):380-385. 
Ramos LR, Veras RP, Kalache A. Envelhecimento populacional: uma realidade brasileira. Rev de Saúde pública. 1987;21(3):211-224.

Reidel B, Thompson JW, Farsiu S, Moseley MA, Skiba NP, Arshavsky VY. Proteomic profiling of a layered tissue reveals unique glycolytic specializations of photoreceptor cells. Mol \& Cell Proteomics. 2011;10(3): M110-002469.

Reyze ML, Caprioli RM. MALDI mass spectrometry for direct tissue analysis: a new tool for biomarker discovery. J Proteome Res. 2005;4(4):1138-1142.

Rodriguez AS, Espina BH, Espina V, Liotta LA. Automated laser capture microdissection for tissue proteomics. Tissue Proteomics. 2008. pp. 71-90.

Russell WK, Park ZY, Russell DH. Proteolysis in mixed organic-aqueous solvent systems: applications for peptide mass mapping using mass spectrometry. Anal Chem. 2001;73(11):2682-2685.

Schenkman M, Ellis T, Christiansen C, Barón AE, Tickle-Degnen L, Hall DA, et al. Profile of functional limitations and task performance among people with early-and middle-stage Parkinson disease. Phys Ther. 2011;91(9):1339-1354.

Scicchitano MS, Dalmas DA, Boyce RW, Thomas HC, Frazier KS. Protein extraction of formalin-fixed, paraffin-embedded tissue enables robust proteomic profiles by mass spectrometry. J Histochem Cytochem. 2009;57(9):849-860.

Seeley EH, Caprioli RM. MALDI imaging mass spectrometry of human tissue: method challenges and clinical perspectives. Trends Biotechnol. 2011;29(3): 136-143.

Sethi S, Chourasia D, Parhar IS. Approaches for targeted proteomics and its potential applications in neuroscience. J Biosci. 2015;40(3):607-627.

Shamoto-Nagai M, Maruyama W, Akao Y, Osawa T, Tribl F, Gerlach M, et al. Neuromelanin inhibits enzymatic activity of $26 \mathrm{~S}$ proteasome in human dopaminergic SH-SY5Y cells. J Neural Transm. 2004;111(10-11):1253-1265.

Sidhu A, Wersinger C, Vernier P. a-Synuclein regulation of the dopaminergic transporter: a possible role in the pathogenesis of Parkinson's disease. FEBS Lett. 2004;565(1):1-5.

Sitek B, Lüttges J, Marcus K, Klöppel G, Schmiegel W, Meyer HE., et al. Application of fluorescence difference gel electrophoresis saturation labelling for the analysis of microdissected precursor lesions of pancreatic ductal adenocarcinoma. Proteomics. 2005;5(10):2665-2679.

Snijders AH, Van De Warrenburg BP, Giladi N, Bloem BR. Neurological gait disorders in elderly people: clinical approach and classification. The Lancet Neurol. 2007;6(1):63-74. 
Spee B, Carpino G, Schotanus BA, Katoonizadeh A, Vander Borght S, Gaudio $\mathrm{E}$, et al. Characterisation of the liver progenitor cell niche in liver diseases: potential involvement of Wnt and Notch signalling. Gut. 2010;59(2):247-257.

Sridharan G, Shankar AA. Toluidine blue: A review of its chemistry and clinical utility. J Oral Maxillofac Pathol. 2012;16(2):251.

Standaert DG. Applications of laser capture microdissection in the study of neurodegenerative disease. Arch Neurol. 2005;62(2):203-205.

Stephenson D, Ramirez A, Long J, Barrezueta N, Hajos-Korcsok E, Matherne, $C$, et al. Quantification of MPTP-induced dopaminergic neurodegeneration in the mouse substantia nigra by laser capture microdissection. J Neurosci Methods. 2007;159(2):291-299.

St Martin JL, Klucken J, Outeiro TF, Nguyen P, Keller-McGandy C, Cantuti-Castelvetri I, et al. Dopaminergic neuron loss and up-regulation of chaperone protein mRNA induced by targeted over-expression of alpha-synuclein in mouse substantia nigra. J Neurochem. 2007;100(6):14491457

Sturm D, Marselli L, Ehehalt F, Richter D, Distler M, Kersting S, et al. Improved protocol for laser microdissection of human pancreatic islets from surgical specimens. J Vis Exp. 2012;71:1875-1876.

Sun L, Zhu G, Yan X, Mou S, Dovichi NJ. Uncovering immobilized trypsin digestion features from large-scale proteome data generated by high-resolution mass spectrometry. J Chromatogr A. 2014;1337:40-47.

Tangrea MA, Mukherjee S, Gao B, Markey SP, Du Q, Armani M, et al. Effect of Immunohistochemistry on Molecular Analysis of Tissue Samples: Implications for Microdissection Technologies. J Histochem Cytochem. 2011;59(6):591-600.

Tepper JM e Lee CR. GABAergic control of substantia nigra dopaminergic neurons. Prog Brain Res. 2007;160:189-208.

Tepper JM, Martin LP, e Anderson DR. GABAA receptor-mediated inhibition of rat substantia nigra dopaminergic neurons by pars reticulata projection neurons. J Neurosci. 1995;15(4):3092-3103.

Tribl F, Gerlach M, Marcus K, Asan E, Tatschner T, Arzberger T, et al. "Subcellular proteomics" of neuromelanin granules isolated from the human brain. Mol \& Cell Proteomics. 2005;4(7):945-957.

Uhlén M, Björling E, Agaton C, Szigyarto CAK, Amini B, Andersen E, et al. A human protein atlas for normal and cancer tissues based on antibody proteomics. Mole \& Cell Proteomics. 2005;4(12):1920-1932. 
Urquhart BL, Atsalos TE, Roach D, Basseal DJ, Bjellqvist B, Britton WL, et al. 'Proteomic contigs' of Mycobacterium tuberculosis and Mycobacterium bovis (BCG) using novel immobilised pH gradients. Electrophoresis. 1997;18(8):13841392.

Van Domburg PHMF, Ten Donkelaar HJ. The human substantia nigra and ventral tegmental area. In:The Human Substantia Nigra and Ventral Tegmental Area. Springer Berlin Heidelberg. 1991;32-69.

Vogel A, Horneffer V, Lorenz K, Linz N, Hüttmann G, Gebert A. Principles of laser microdissection and catapulting of histologic specimens and live cells. Methods Cell Biol. 2007;82:153-205.

Vrana JA, Gamez JD, Madden BJ, Theis JD, Bergen III HR, Dogan A. Classification of amyloidosis by laser microdissection and mass spectrometrybased proteomic analysis in clinical biopsy specimens. Blood. 2009;114(24): 4957-4959.

Wang H, Owens JD, Shih JH, Li MC, Bonner RF, Mushinski JF. Histological staining methods preparatory to laser capture microdissection significantly affect the integrity of the cellular RNA. BMC genomics. 2006;7(1):97.

Wang JH, Gouda-Vossos A, Dzamko N, Halliday G, Huang Y. DNA extraction from fresh-frozen and formalin-fixed, paraffinembedded human brain tissue. Neuroscience Bulletin. 2013;29(5):649-654.

Wang WZ, Oeschger FM, Lee S, Molnár Z. High quality RNA from multiple brain regions simultaneously acquired by laser capture microdissection. BMC mol bio. $2009 ; 10(1): 69$.

Watarai H, Inagaki Y, Kubota N, Fuju K, Nagafune J, Yamaguchi Y, et al. Proteomic approach to the identification of cell membrane proteins. Electrophoresis. 2000;21(2):460-464.

Weintraub D e Stern MB. Psychiatric complications in Parkinson disease. Am J Geriatr Psychiatry. 2005; 13(10):844-851.

Wuhrer M, Koeleman CA, Deelder AM. Two-dimensional HPLC separation with reverse-phase-nano-LC-MS/MS for the characterization of glycan pools after labeling with 2-aminobenzamide. In: Glycomics. Humana Press. 2009:79-91.

Xu BJ, Caprioli RM, Sanders ME, Jensen RA. Direct analysis of laser capture microdissected cells by MALDI mass spectrometry. J Am Soc Mass Spectrom. 2002; 13(11), 1292-1297.

Zecca L, Fariello R, Riederer P, Sulzer D, Gatti A, Tampellini D. The absolute concentration of nigral neuromelanin, assayed by a new sensitive method, increases throughout the life and is dramatically decreased in Parkinson's disease. FEBS lett. 2002;510(3):216-220. 
Zhang W, Zecca L, Wilson B, Ren RW, Wang YJ, Wang XM, et al. Human neuromelanin: an endogenous microglial activator for dopaminergic neuron death. Front Biosci (Elite edition). 2013;5:1.

Zhou Z, Licklider LJ, Gygi SP, Reed R. Comprehensive proteomic analysis of the human spliceosome. Nature. 2002;419(6903):182-185.

Zucca FA, Basso E, Cupaioli FA, Ferrari E, Sulzer D, Casella L, et al. Neuromelanin of the human substantia nigra: an update. Neurotox Res. 2014;25(1):13-23.

Zucca FA, Giaver, G, Gallorini M, Albertini A, Toscani M, Pezzoli G, et al. The neuromelanin of human substantia nigra: physiological and pathogenic aspects. Pigment Cell Res. 2004;17(6):610-617. 